\title{
AQREGLTHRAL CHANGES
}

AND

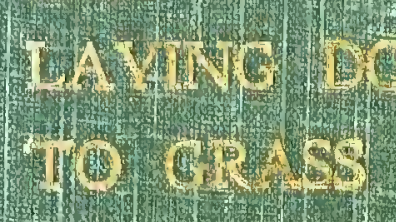




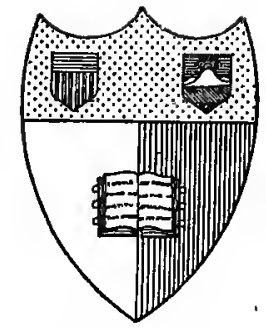

New 期atk

State Gallege of Anrirulture

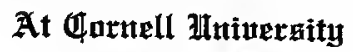

Jthara, N. 1 .

\section{Tithrary}


S 455.E46 ${ }^{\text {Cornell University Library }}$

The agricultural changes required by the

IIII.

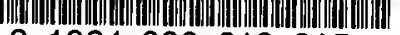

31924000219315

mann 


\section{Corncll University Library}

The original of this book is in the Cornell University Library.

There are no known copyright restrictions in the United States on the use of the text. 



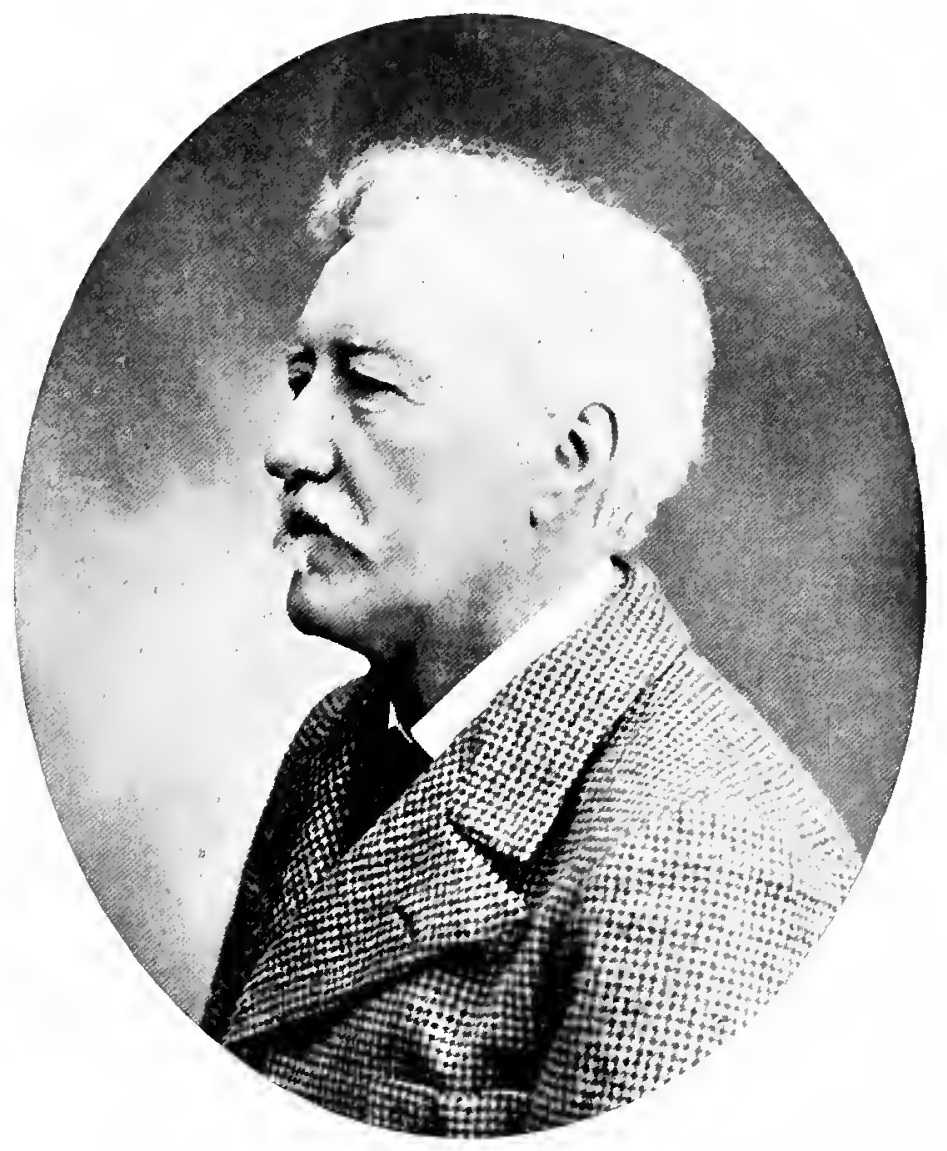

ROBERT H. ELLIOT, of Clifton Park. 


\section{ㄷ․}

\section{Agrìcultural Changes}

\section{Required by these Times,}

AND

\section{Laying Down Land to Seass.}

\section{BY \\ ROBERT H. ELLIOT,}

AUTHOR OF "THE EXPERIENCES OF a PLANTER," "GOLD, SPORT, AND COFFEE PLANTING IN MYEORE," ETC.

[Third Edition, with the most recent Experiments, up to the end of October, 1904.]

"The study of grasses would be of great consequence to a northerly and grazing kingdom. The botanist that could improve the sward of the district where he lived would be a useful member of society; TO RAISE A THICK TURF ON A NAKED SOIL WOULD BE WORTH VOLUMES OF SYSTEMATIC KNOWLEDGE; and he would be the best Commonwealth's man that could occasion the growth of two blades of grass where one alone was seen before."-White's "Natural History of Selborne."

K EL S O :

J. \& J. H. R U T H R F R D, Honorury Publishers and Stationers to the Border Union Agricultural Society. 1905. 

K ELSO:

Printed by Johx M“Arthor, "Chronicle" Printing Works. 
"After the rudiments of education and religious instruction, the next step would be with authors of agriculture, Cato, Varro, and Columella, . . . and here will be an occasion of inciting and enabling them hereafter to improve the tillage of their country, to recover the bad soil, and to remedy the waste that is made of good." -Milton. 


\title{
to the Mnemory.
}

\author{
of the late
}

$\mathfrak{M}_{\mathfrak{r}}$. Jaunce de Zaune. 



\section{P R E F A C E}

\section{TO THE FIRST EDITION.}

I HAVE dedicated this book to my late really-to1 be-lamented friend, Mr. Faunce de Laune of Sharsted Court, Kent, because I, in common with a vast number of landowners and farmers, owe him a great deal of gratitude for having, in his article "On Laying. Down Land to Permanent Pasture,"* been the means of calling attention to the once deplorable condition of the British seed trade. This is sufficiently exemplified by a single quotation from the article alluded to, and in which Mr. De Laune says:- "I found that, however careful I was in my orders, and from whatever seed merchant I ordered my seed, the per centage of ryegrass, soft woolly grass, and other bad grasses and weeds, was beyond all belief." My own experience, I am sorry to say, was the same as that of Mr. De Laune's, and in some cases a botanist I employed could not discover a single plant of some of the more valuable grasses the seeds of which I supposed I had put down, and

* Journal of Royal Agricultural Society of England. Part I., No. xxxv. 1882 . 
which, of course I had paid for. But my friend's article at once aroused the trade and the public, and led to that system of guaranteeing seed which was initiated by Mr. James Hunter, the wellknown seed merchant of Chester, whose treatise on permanent pasture has, I may mention in passing, been highly and justly commended by Mr. De Laune. My friend has often been urged by me to bring out a book on the subject of laying down land to grass, and I am given to understand that he had made preparations for the work; but after his death all that could be discovered amongst his papers were some proofs, which were evidently those of his articles in the Journal of the Royal Agricultural Society, though a good many passages, one of which I have quoted (vide page 21), must have been deleted. The following brief notice of Mr. De Laune will be interesting to his friends, and also, I hope, to many of those who, like myself, have benefited by his work:-

Mr. Faunce de Laune came of an old Kentish family, and one of his ancestors-a naval officerwas present at the attack on the Spanish Armada in the year 1588. The family suffered much in the civil wars, and one of them was knighted at the Restoration for his loyalty to the Royal cause. My late friend was born in 1843, succeeded his father in 1861, and died in 1891 from an illness 
when travelling in India. He was a man of many accomplishments and varied interests, much travel in various parts of the world, and was always a most agreeable companion. He was fond of sport, a good man across country, and possessed of all those physical and mental energies which are indispensable to success in most branches of life. Though he wrote and spoke on other subjects, he was chiefly known for the grest interest he took in agriculture and fruit growing, and also for his experiments as regards the cultivation of home-grown tobacco. But, as we have seen, the work of greatest value to the agricultural world was that connected with laying down land to grass. This I followed up in Scotland, both by writing, lecturing, and experimenting on a large scale; and if $I$ have in any degree been the means of improving the mixtures now being used, and diminishing the weeds which the farmers once sowed with their grass seeds, it is entirely owing to the initiative of my late friend, the consequential value of whose work it would, indeed, be difficult to over-estimate. He was appointed one of the governors of the Royal Agricultural Society of England, and, had he not been so unfortunately cut off, would, no doubt, have contributed still further to the progress of agriculture in great Britain.

I have much pleasure, in conclusion, in acknow- 
ledging my obligations to Mr. James Hunter, who has been kind enough to supply me with the remarks and valuable tables which the reader will find in the Appendices.

\section{ROBERT H. ELLIOT.}

Cliffton Park, Kelso,

RoXBURGHSHIRE, Octoher 18, 1898. 


\section{P R E F A C E}

\section{TO THE SECOND EDITION.}

THE first edition of this book was printed for 1 private circulation, and many copies were given away-mostly to persons personally unknown to me. From the numerous letters I have received asking for advice, and the many agricultural visitors to the farm from Scotland and England, I am now satisfied that a book on the subject is urgently needed. I therefore publish what I have previously written, and have added an account of our most recent experiences.

I may add that my object throughout has been to show how the farmer can steadily improve his condition and the fertility of the soil, and at the same time diminish his expenditure. I need hardly say that, under the present condition and future prospects of the labour market, these points must be carried out in order to place our agriculture on a sound footing.

\section{ROBERT H. ELLIOT.}

Chifton Park, November 7, 1900. 


\section{PREFACE}

\section{TO THE THIRD EDITION.}

QINCE the publication of the second edition $D$ much valuable experience has been gained, and, as the second edition of 1000 copies is nearly exhausted, I beg to offer the present edition to the agricultural world, and this Preface to every Englishman who feels any interest in our national welfare. This book shows how vast sums now spent on imported manures and feeding stuffs may be saved, how crops may be successfully grown on land that has become almost derelict, how the decline of employment in our rural districts may be arrested, and, further, how it may be gradually increased. The proofs of these statements are open to anyone who chooses to visit the Clifton-on-Bowmont farm, which has been visited by many hundreds of practical farmers from many parts of these islands. The valuable confirmatory opinions I have received have amply compensated me for the time and labour I have expended on this subject. For many years past we have been doing what ought to have been the work of an agricultural de- 
partment; our correspondence has reached far beyond these islands, and it may be of interest to mention that we have heard on the subject, either directly or indirectly, from India, Chili, Pert, the Argentine Republic, the Antipodes, and Canada. From the many confirmatory opinions I have received I quote the following from a Roxburghshire tenant farmer, as it illustrates so conclusively the national importance of the work that has been carried to most successful results at Clifton-onBowmont. The passage, I may mention, has already appeared in my letter in the Times, under the heading of "Agricultural Depression," on October 12, 1904. The tenant farmer alluded to writes as follows :-

"From the short experience I have had on my farm of practising a modification of your system I am now thorougbly convinced that most of the poor land in this country could be profitably farmed and give more employment to labour than it possibly can do at present. Clifton-on-Bowmont proves beyond question how much can be done to cheapen production and maintain the fertility of the land through natural and scientific methods. Your example should prove a guide and a warning to many who would run to extremes in laying too much land, thought worthless for growing crops, to grass of inferior quality. Such land can never be profitably held in that way. Cliftonon-Bowmont teaches a different lesson, and conclusively proves that much poor land going out of cultivation, and carrying a poor, short stock in consequence, can be successfully cropped by a proper rotation; and that, instead of driving more people off the land to make room for a few sheep, it can be made to give employment to more people, and produce much more and better sheep. This is the first year I have adopted your system as 
regards cropping, and I am highly pleased with the results so far, as I never had turnips do so well, and the system saves certainly 30 per cent. in labour and manure. By another year I hope to work much more of my land on your system."

But the system, which is now widely known as the Clifton Park system, will do much more than produce the effects so forcibly pointed out by my correspondent. It will arrest the steady decadence of all British arable soils. For the last thirty years I have had them through my hands on a large scale, from alluvial flats up to thin soil 800 feet above the level of the sea, and find an only too ample confirmation of the general complaint of practical farmers. At the first great meeting of 400 Aberdeenshire farmers, held more than twenty. years ago, exhaustion of the soil was declared to be one of the greatest causes of their difficulties. In the course of discussion with ten leading farmers at Clifton-on-Bowmont last year all seemed to agree in thinking that the soil had declined owing to the exhaustion of organic, or vegetable, matter. With the aid of liming, and a freer and freer use of artificial manures, the decadence thus caused is steadily continuing. And the farmer expects that foreign competition may be met by ever augmenting bills for purchased fertilizers, which will cause the soil still further to decline in fertility, while the agricultural chemist, aided by the manure merchant, is emptying his pockets, and at the same time enabling the farmer to run out the 
remaining fertility of the soil. When, some months ago, I told a very old and experienced practical farming friend that I purposed to grow a fine crop of turnips without the aid of any manure he laughed in my face, and evidently thought the assertion the best joke he had heard for some time; yet this has been done, and on land that never has had any farmyard manure, and the previous turnips of which had only received some artificials. With reference to the successful growing of crops without any other manure excepting that of a turf grown on the spot, and consisting of deeply-rooting plants, combined with a full supply of the leguminosæ, the correspondent previously quoted writes as follows :-

"There is one point which always strikes me, as also many others, when visiting Clifton from time to time, and that is the remarkable fact of seeing such crops from year to year [the farm has now been in the proprietor's hands for 17 years] when so much breeding stock is raised and sold off the place, and so little feeding stuff consumed-practically none. I know of no other secondary arable farm in this country farmed on the old system, and sown down every year with ordinary grass mixtures, that would continue to grow paying crops unless a very great amount ol cake-fed manure, or other artificials, were applied to the turnip break every year. Even valuable old pastures quickly degenerate where a breeding stock, or young animals, are kept without extra cake feeding. Looking at these facts, it is all the more remarkable how much your system and scientific seeding has accomplished on poor high land such as Clifton-on-Bowmont. Your wonderful success in growing potatoes also raises the question of how much might be made from that valuable crop through cheap production by natural means, and practically no 
other expenses than the labour of planting and lifting, in contrast to the regular potato districts, with their high rents and enormous expenditure of artificial and farmyard manure."

High farming on the old lines is no remedy for low prices. For our sole resource in the face of foreign competition we must look to an economy of production which will carry with it, free of expenditure on commercial fertilizers, an increasing fertility of soil. These objects have throughout been kept steadily in view, and have been successfully carried out at Clifton-on-Bowmont.

It is remarkable, or perhaps it is not remarkable, that the Board of Agriculture should have not only failed to distribute leaflets on this important subject, but should even have declined to send (as I suggested it should) to the various County Councils notices of the work at Cliftonon-Bowmont, on the ground that for it to do so would be to identify itself with a system-the principles of my system being as old as agriculture, though the method of carrying them out may be new, and, so far as I know, is new.

I have much pleasure in acknowledging my obligations to Dr. Voelcker and Mr. James Hunter, who have throughout taken great interest in the work at Clifton-on-Bowmont, and supplied me with much valuable matter, which will be found in the appendices.

ROBERT H. ELLIOT.

Clifton Park, October 22, 1904. 


\section{CONTE NTS.}

\section{CHAPTER I.}

I N T ROD OCTORY.

Author's opportunities for forming sound conclusions us to the changes required by the times $\begin{array}{lllllll} & \ldots & \ldots & \ldots & \ldots & 1\end{array}$

$\begin{array}{llllll}\text { Remodelling our agricultural system } & \ldots & \ldots & \ldots & \mathbf{2}\end{array}$

The writings of Arthur Yonng. The importance of local experieuce. New system of farming suitable to the habits of

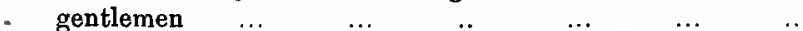

New system of farming provides deeply-tilled, humus-fed soil, ensuring good crops

British agriculture will revive if suitable changes of system are made. The exhaustion of the soil a clief cause of our agricultural difficulties ...

Proposed changes are to the mutual advantage of landlords and tenants. Similar principles were laid down by M. Porcius $\begin{array}{lllllll}\text { Cato } 2000 & \text { years ago } & \ldots & \ldots & \ldots & \ldots & \ldots\end{array}$

Why farmers oppose agricultural changes of system. Farmers rarely enquire about agricultural questions $\quad \ldots \quad \ldots$

The falsity of the old saw as to "making a pasture breaking a man." Agricultural changes adopted in Normandy ...

Agricultural schools and experimental farms aid the Normandy farmers. Great Britain requires Government agricultural schools and experimental farms $\ldots \quad \ldots \quad \ldots \quad \ldots \quad \ldots$

CHAPTER II.

GENERAL PRINCIPLES.

The dominating principles as regards the required change of $\begin{array}{llllllll}\text { system } & \ldots & \ldots & \ldots & \ldots & \ldots & \ldots & 10\end{array}$

Bimetalism and Protection are of no value to agriculture $\quad \ldots \quad 11$

Land legislation no cure for our agricultural difficulties. Farm. ing more profitable when rents were higher $\quad \ldots \quad \ldots$

The cheap production of a good sod is the leading feature in the system recommended. A mixture composed of powerful and deep-rooting plants will at once till, manure, and clean the land...

Crops less liable to disease. Finger-and-toe. Weeds abolished... 
Locke's " Conduct of the Understanding"

Lord Leicester's system of farming light lands

Seed mixture used by Lord Leicester. Author's proposcd mixture will provide a much better turf in much less time ...

\section{CHAPTER III.}

ON DISINTEGRATING THE SOIL AND PERMEATING IT WITH VEGETABLF MATTER.

Sir John Lawes' opinion on the importance of good physical condition of soil. Mr. Faunce de Laune's opinion on the same point

Interesting proof of the physical being of even more importance than the, strictly speaking, chemical condition of the soil

When laying down to permanent pasture land deficient in vegetable matter it must be supplied $\quad \ldots \quad \ldots \quad \ldots$

The cheapest and easiest way to remedy the deficiency of $\begin{array}{lllllll}\text { vegetable matter in the soil } & \ldots & \ldots & \ldots & \ldots & 26\end{array}$

Illustrations of soil disintegration by the agency of roots $\quad \ldots \quad 27$

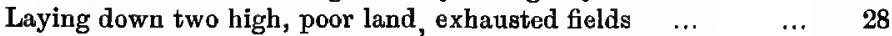

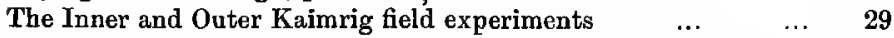

Remarkable results obtained after relaying one of the fields $\quad \ldots \quad \quad 30$

Practical illustrations of the great value of drought-resisting plants, such as chicory, burnet, kidney vetch, and yarrow ...

The value of burnet and yarrow in keeping sheep in good health, and especially in diminishing diarrhcea. Deep and strongrooting plants will almost extinguish couch grasses, and $\begin{array}{llllllll}\text { lessen moss } & \ldots & . . & \ldots & \ldots & \ldots & \ldots\end{array}$

Turnips grown without manure. The system of farming recommended is an extremely simple one $\quad \ldots \quad \ldots \quad \ldots$

Farmers do not know how to act, as they are not aided by Government schools and farms as agriculturists are abroad. Great losses caused owing to want of proper means of instruction

.. $\quad \ldots \quad \ldots \quad \ldots \quad \ldots$

Efforts of County Councils of but little practical value to farmers

The system of instruction that should be adopted

\section{CHAPTER IV.}

ARTHUR YOUNG, AND SOME OF HIS AGRICULTURAL EXPERILNCES WITH REFERENCE TO CHICORY, BURNET, AND OTHER FORAGE PLANTS.

Brief account of his life and works $\ldots \quad \ldots$
His great unpublished work-"The Elements and Practice of $\begin{array}{lllllll}\text { Agriculture } " \ldots & \ldots & \ldots & \ldots & \ldots & \ldots\end{array}$

Chicory introduced into England by Arthur Young in 1788. $\begin{array}{lllll}\text { French 'experiences of it } \quad \ldots & \ldots & \ldots & \ldots\end{array}$

Chicory suits poor lands and all kinds of soil. All stock does well on it. Proofs that chicory is at least equal to any plant in this climate... 
Chicory does not suffer in dry weather like burnet and sainfoin...

Summary of valuable points connected with chicory. Advantages and disadvantages of chicory $\quad \ldots \quad \ldots \quad \ldots \quad \ldots \quad \ldots$

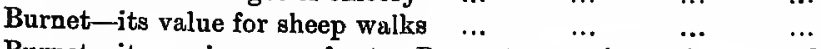

Burnet-its use in cases of rot. Prevents scouring. An acre of $\begin{array}{llll}\text { burnet equal in consumption to any acre of turnips } & \ldots & 47\end{array}$

$\begin{array}{lllllll}\text { Various forage plants } & \ldots & \ldots & \ldots & \ldots & \ldots & 48\end{array}$

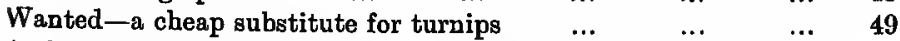

Arthur Yonng's experience of ronen, or aftermath preserved for spring use. Its value in the counties in which it was used. A shilling spent in rouen goes as far as a guinea spent in turnips. Experiment with rouen

Rouen equally valuable in severe winters. Earl of Exeter prefers rouen to turnips, and found his flock healthier for the substitution

The use of fog, or the growth of the whole year preserved for winter and spring use. An acre of fog superior to an acre of hay. Improving a meadow by sowing with winter tares and white clover after harrowing and top-dressing. Young's experiences as to various methods of laying down land to $\begin{array}{lllllll}\text { grass ... } & \ldots & \ldots & \ldots & \ldots & \ldots & \ldots\end{array}$

$\begin{array}{llllllll}\text { Young's remarks on various grasses } & \ldots & \ldots & \ldots & \ldots & 53\end{array}$

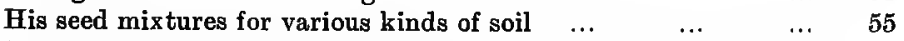

Subsequent management of pasture. Cutting faggots of branches in full leaf for winter use. Great saving of hay effected by this practice. Arthur Young's admirable mental and physical qualities

\section{CHAPTER V.}

LAYING DOWN LAND TO GRASS AND THE TREATMENT OF THE PASTURE.

Remarks on grass in Dr. Keith's " Agriculture of Aberdeenshire," 1811. Dr. Anderson's original report and his remarks on ryegrass. An agricultural book should be brought out by Government for every county in Great Britain ... ...

"Observations on British Grasses," a paper in Dr. Keith's book remarking on causes of failures in laying down land to grass - chiefly owing to use of ryegrass. Other causes of failurewant of vegetable matter in land and consequent consolida$\begin{array}{llllllll}\text { tion } \text { of soil } & \ldots & \ldots & \ldots & \ldots & \ldots & \ldots\end{array}$

$\mathrm{My}$ own system of laying down with a light grain crop. $\mathrm{Mr}$. Wilson's system of laying down with tares $\ldots . .$.

Varions methods described by Arthur Young. Particulars of $\begin{array}{lllllll}\text { Mr. Wilson's system } & \ldots & \ldots & \ldots & \ldots & \ldots\end{array}$

Mr. Faunce de Laune's experience. After management of pasture even of more importance than the selection of the seed and preparation of the soil ... $\quad \ldots \quad \ldots \quad \ldots$

Evils arisiog from grazing young pastures during first autumn. Importance of rolling the land after grasses have come up ... 
Pastures should not be over-stocked the first year

Importance of re seeding vacant patches in pastures

$\begin{array}{llllllll}\text { Moss in pastures } & \ldots & \ldots & \ldots & \ldots & \ldots & \ldots & 68\end{array}$

Treatment of the pasture in the third and fourth year... $\quad \ldots \quad 69$

How to get most winter and spring keep ont of pastures, and $\begin{array}{llllll}\text { thus reduce cost of feeding stock } & \ldots & \ldots & \ldots & 70\end{array}$

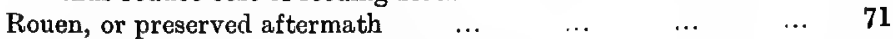

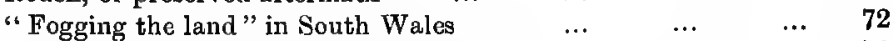

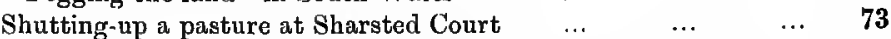

Advantages of this as regards re-seeding and prevention of moss

Our hill pastures might be much improved if treated in blocks on the Welsh fogging system. Risk from snow not serious. With the aid of rouen, "fogging the land," and oilcake, turnips and cereals can be largely diminished, and the cost of producing stock diminished

\section{CHAPTIR VI.}

F ORAGE PLANTS.

Danger of regulating present practices by previous customs which may not be founded on a sound experience ... ...

Cause of the preference for ryegrass. Mr. James Hunter's note $\begin{array}{llllllll}\text { thereon } & \ldots & \ldots & \ldots & \ldots & \ldots & \ldots\end{array}$

Sinclair's opinions as to cocksfoot being superior to ryegrass, and affording a greater quantity of vegetable matter to the soil. The effect of plant roots on the soil

The grass mixtures usually sown not founded on sound principles. New mixtures used by author ...

Proofs of the great value of deep-rooting plants for breaking up hard pans. Value of chicory roots in keeping soil soft and

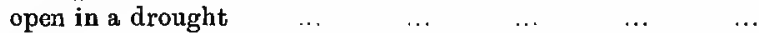

Chicory, burnet, and kidney vetch as subsoilers $\quad \ldots \quad$... 83

Chicory superior to parsnip as a deep-rooter ... $\quad \ldots \quad$.. 84

Opiuions of a well-known farmer as regards two poor land fields... 85

Results would have been far more surprising had sheep been fed with oilcake

...

Importance of careful tillage and seeding. Liberal seeding most essential to success

$\begin{array}{lllll}\text { Arthur Young considered liberal seeding essential } & \ldots & \ldots & 88\end{array}$

The number of germinating seeds required to sow an acre $\quad \ldots \quad 89$

Quality of seed of great importance. Great differences in the results from different qualities of seeds $\ldots$...

The Lake field laid down with seeds from two different sources, and the results. Effects of inferior seeds perceptible for $\begin{array}{lllllll}\text { many years } & \ldots & \ldots & \ldots & \ldots & \ldots & \ldots\end{array}$

Differences in plants grown from seed produced in various

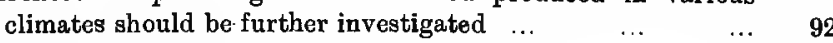

$\begin{array}{lllllll}\text { Remarks on cocksfoot } & \ldots & \ldots & \ldots & \ldots & \ldots & 93\end{array}$ 


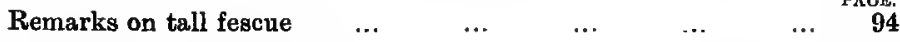

$\begin{array}{llllllll}\text { Remarks on tall oat grass } & \ldots & \ldots & \ldots & \ldots & \ldots & 95\end{array}$

Tall oat grass, cocksfoot, and tall fescue the most productive of the tall grasses, and also early and drought-resisting $\quad \ldots \quad 96$

Mixture suggested composed of hardy, drought-resisting, health-

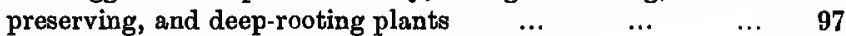

Remarks on timothy

$\begin{array}{llllll}\text { Remarks on Italian ryegrass } & \ldots & \ldots & \ldots & \ldots\end{array}$

Remarks on perennial ryegrass, meadow fescue, and meadow foxtail

$\begin{array}{llllll}\text { Poa fertilis, or late-flowering meadow grass } & \ldots & \ldots & \ldots & 101\end{array}$

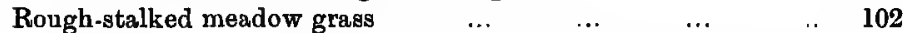

Golden oat grass, smooth-stalked meadow grass, and hard $\begin{array}{lllllll}\text { fescue } & \ldots & \ldots & \ldots & \ldots & \ldots\end{array}$

Sweet vernal, crested dogstail, wood meadow grass, fine-leaved fescue

Nerved meadow grass

Yarrow and kidney vetch ...

Birdsfoot trefoil and parsley

Lucerne and draw moss

$\begin{array}{lllll}\ldots & \ldots & \ldots & \ldots & 104 \\ \ldots & \ldots & \ldots & \ldots & 105 \\ \ldots & \ldots & \ldots & \ldots & 106 \\ \ldots & \ldots & \ldots & \ldots & 107 \\ \ldots & \ldots & \ldots & \ldots & 108\end{array}$

\section{CHAPTER VII.}

WHY GOVERNMENT EXPERIMENTAL FARMS ARE SO SPECIALLY NEEDED, AND THE LINES ON WHICH THEX SHOULD BE LAID.

Aversion of agriculturists to intellectual exertion

The mental condition of landlords, tenant farmers, and factors in regard to agricultural matters...

Need for experimental farms for the instruction of the classes connected with land. Visitors to Clifton-on-Bowmont farm

The Board of Agriculture and its present policy

"Can the blind lead the blind?" Experiments at Cockle Park, Morpeth

The exhaustion of humus not remedied by the use of artificial manures

Manurial experiments with hay crops and potatoes at Cockle Park ...

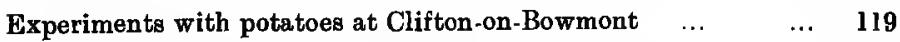

Experiments with sheep at Cockle Park $\quad \ldots \quad \ldots \quad 120$

Two sets of experiments required on experimental farms $\quad \ldots \quad 122$

The Government asked to take lease of Clifton-on-Bowmont experimental farm

Government inaction in matters relating to agriculture. Central seed-testing station not yet established 


\section{A P P E N D I C E S.}

ApPendix I. - Paper contributed by Mr. James Hunler, agricul. tural seed merchant, Chester :-

Table showing the germination, weight, number, and cost of the various species of grass and clover seeds

The quantity and cost of grass and clover seeds required

The relative productiveness of the various species of grasses

Grasses in the order of their cost for seeds to sow an acre.

Grass mixtures for permanent pasture on poor dry soils

Grass mixtures for permanent pasture in a moist climate .

Note by $\mathrm{Mr}$. James Hunter on more seed being required

APPENDIX II.-Remarks on some notes on the seed trade

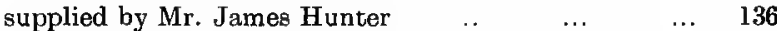

How purchasers can be sure of buying the best seeds $\quad \ldots \quad 137$

Appendix III.-Experiences up to the end of October, 1904 :-

$\begin{array}{llllll}\text { The Outer Kaimrig experiment... } & \ldots & . . & \ldots & 138\end{array}$

$\begin{array}{lllllll}\text { The Bankfield experiment } & \ldots & \ldots & \ldots & \ldots & 139\end{array}$

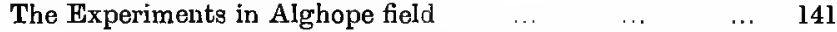

The Clifton Park system of grass-growing on poor clay soil at Abbotsley, Hunts., under the auspices of the Cambridge University Department of Agriculture ..

Mixture of drought-resisting plants for bare rocky surfaces 143

$\begin{array}{llllll}\text { Growing potatoes without manure } & \ldots & \ldots & \ldots & 144\end{array}$

$\begin{array}{llllll}\text { Turnips grown without manurc .. } & \ldots & \ldots & \ldots & 144\end{array}$

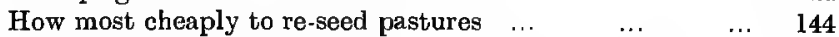

Importance of rolling land when laying down to grass $\quad . \quad \mathbf{1 4 5}$

$\begin{array}{llllll}\text { Causes of young pastures failing } & \ldots & \ldots & \ldots & 145\end{array}$

$\begin{array}{llllll}\text { Importance of drought-resisting plants } & \ldots & \ldots & \ldots & 146\end{array}$

$\begin{array}{llllll}\text { Aftermath must be lightly grazed } & \ldots & \ldots & \ldots & 146\end{array}$

$\begin{array}{lllll}\text { Effects of system in preventing loss from wash } & \ldots & \ldots & 147\end{array}$

$\begin{array}{llllll}\text { Effects of system in abolishing weeds } & \ldots & \ldots & \ldots & 147\end{array}$

$\begin{array}{llllll}\text { Effects of haying land first year } & \ldots & \ldots & \ldots & 147\end{array}$

On the quantity of clover seed that should be used $\quad \ldots \quad 148$

$\begin{array}{lllll}\text { Filling up vacant spots in first year's grass } & \ldots & \ldots & 148\end{array}$

Letting up fogged-up or mossed-up hill pastures ... $\quad \ldots \quad 149$ 
Moss : Important result in Outer Kaimrig

$\begin{array}{llllllll}\text { Grass inoculation } & \ldots & \ldots & \ldots & \ldots & \ldots & 149\end{array}$

Success of the system as regards crops, stock, and culti$\begin{array}{llllllll}\text { vation } & \ldots & \ldots & \ldots & \ldots & \ldots & \ldots & 150\end{array}$

Effect of system after plongbing the second turf ... $\quad \ldots \quad 150$

Safety of the system as regards hay and pasture ... $\quad . . \quad 151$

Decomposition of vegetable matter more rapid on warm $\begin{array}{lllllllll}\text { slopes } & \ldots & \ldots & \ldots & \ldots & \ldots & \ldots & 151\end{array}$

Manures used for turnips at Clifton-on-Bowmont... $\quad \ldots \quad 152$

Difference between five-course rotation and that on my $\begin{array}{lllllllll}\text { farm } & \ldots & \ldots & \ldots & \ldots & \ldots & \ldots & 152\end{array}$

Comparison of the results of the new system at Clifton-on-

Bowmont with those of an adjacent farm $\quad \ldots \quad \ldots \quad \ldots \quad 152$

$\begin{array}{lllll}\text { Success of the system as regards turnip disease } & \ldots & \ldots & 153\end{array}$

Land increases in fertility even though a breeding stock is $\begin{array}{lllllllll}\text { kept } & \ldots & \ldots & \ldots & \ldots & \ldots & \ldots & 154\end{array}$

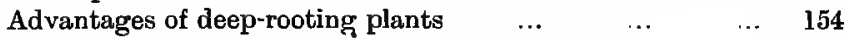

The downward penetration of chicory and burnet $\quad \ldots \quad 155$

$\begin{array}{llllllll}\text { Effects of ryegrass } & \ldots & \ldots & \ldots & \ldots & \ldots & 157\end{array}$

$\begin{array}{lllllll}\text { General success of the system } & \ldots & \ldots & \ldots & \ldots & 159\end{array}$

$\begin{array}{llllllll}\text { Financial results } & \ldots & \ldots & \ldots & \ldots & \ldots & 161\end{array}$

$\begin{array}{llllll}\text { The cheapest mixturcs of grass seeds } & \ldots & \ldots & \ldots & 162\end{array}$

$\begin{array}{llllll}\text { The work of the Board of Agriculture } & \ldots & \ldots & \ldots & 165\end{array}$

$\begin{array}{llllllll}\text { Concluding remarks } & \ldots & \ldots & \ldots & \ldots & \ldots & 167\end{array}$

APPENDIX IV. - Note by Dr. Voelcker on comparison of the soils of old Cheviot turf and five-year-old pasture ... $\quad \ldots \quad 169$

Second note by Dr. Voelcker on the composition and character of the soil of the Bankfield

$\begin{array}{llllllll}\text { APPENDIX V. - Shelters } & \ldots & \ldots & \ldots & \ldots & \ldots & 173\end{array}$

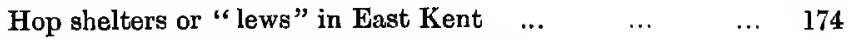

APPENDIX VI.-Suggested changes of farming system :-Paper read at a meeting of Border Union Agricultural Society, October, 1902

APPENDIx VII.-The clover mystery; a probable solution of it :- Paper read at the meeting of the British Association for the advancement of science, at Cambridge, August 19, 1904 ... $\quad$.. $\quad \ldots . \quad \ldots \quad$...

Postscript to paper read at the meeting of the British

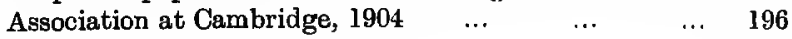




\section{List of fllugtrations.}

Portrait-Mr. Robert H. Elliot of Clifton

$\begin{array}{llllllll}\text { PARK } & \ldots & \ldots & \ldots & \ldots & \ldots & \text { Frontispiece. }\end{array}$

$\begin{array}{lllllll}\text { VIEW OF Clifton Park } & \ldots & \ldots & \ldots & \text { facing page } & 1\end{array}$

Portrait-Mr. C. de Laune Faunce de laune

(THE Late) of Sharsted Court ... $\quad \ldots$ facing page 21

Portratt-Mr. James Hunter, Chester facing page 110

Map of Clifton-on-Bowmont Farm $\quad \ldots \quad \ldots$ facing page 198 



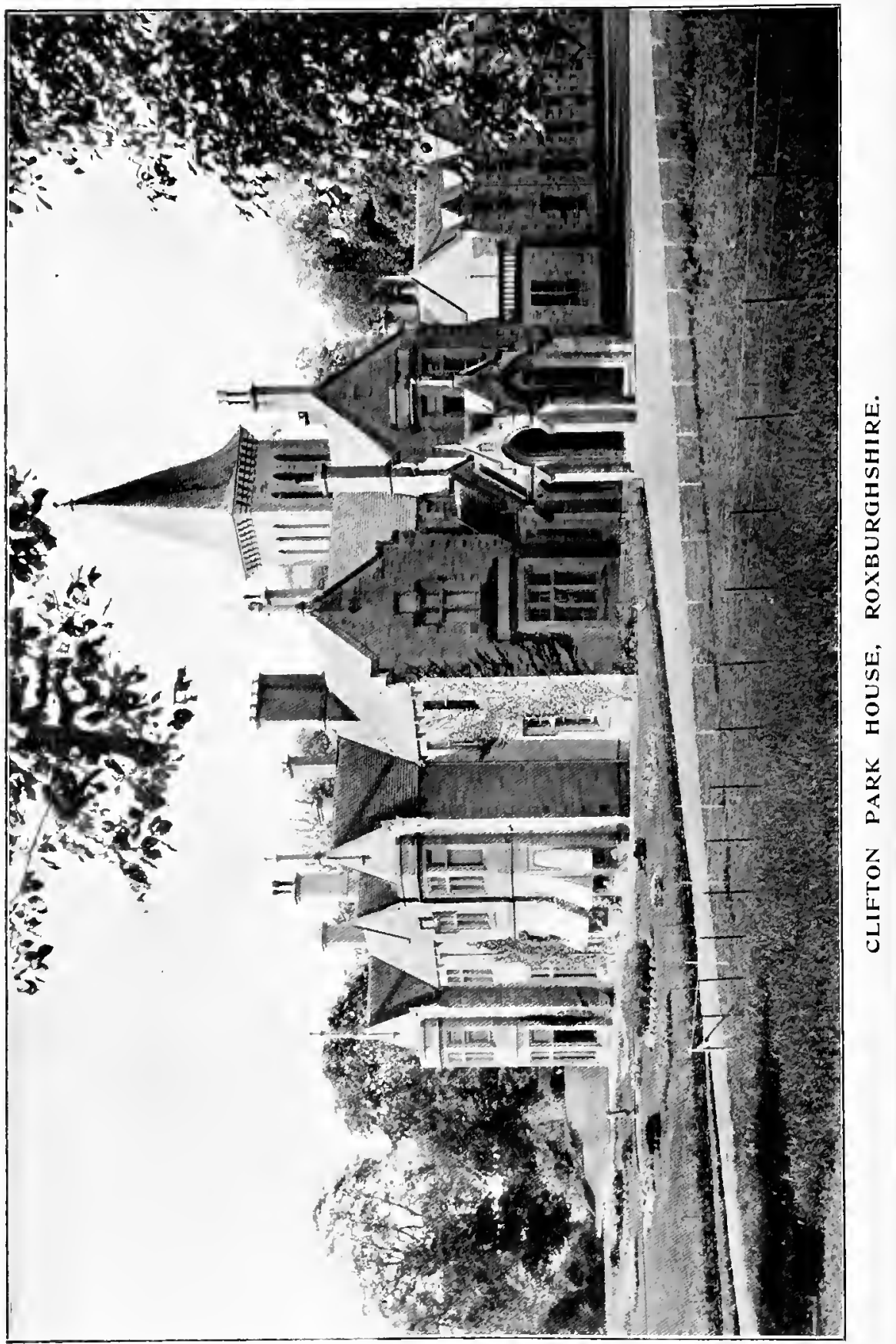




\section{. THE . \\ AGRICULTURAL CHANGES}

\section{REQuiRed By These TIMES, AND}

\section{How to Carry Them Out.}

\section{CHAPTER I.}

\section{IN'TRODUCTORY.}

T'T will, I think, be satisfactory to the reader to be 1 told at the ontset that $I$ am an agriculturist by profession, having started as such in 1856 in India as a practical planter-i.e., a planter managing and working his own land. For the last thirty years I have farmed land on my property in Roxburglishire, and still have in my occupation a farm of about 1250 acres. The opportunities I had for being acquainted with the world-wide causes which were sure to bring about a serious state of agricultural conditions in these islands showed me that a thorough reorganization of our farming system was necessary in order to bring it into line with the altered conditions caused by foreign competition, and the rapidly-increasing transport facilities which were sure to bring the produce of the world more and more cheaply to our doors. 'To myself, 
then, and to others who had equal opportunities of making sound forecasts, it was evident that a system of cultivatiou depending largely on cereals would have to give way to one mainly depending on the cultivation of grass and forage plants, and also on cheapening the cost of production all along the line, for it was evident that if other countries could produce so much more cheaply than we can we must produce more cheaply than we do now or go to the wall. It was extremely easy to conceive these ideas, and I accordingly at once proceeded to attempt to put them into execution; but I was not long in discovering that $I$ had got hold of a very difficult and complicated subject, and so much so, indeed, that it is only now, after about thirty years' practical experience on a large scale, and after numerons experiments on all kinds of soil, and at many different elevations, that I feel myself able to offer to the agricultural world experiences and conclusions that will, I venture to think, be of use in the work of remodelling our own agricultural system so as to bring it into harmony with the existing state of things throughout the world. But though I have no doubt that my experiences will be of value, I need hardly say that, before adopting any of the changes to be advocated in these pages, the agriculturist must weigh carefully the whole of his own local conditions, and see that, if he adopts any of my conclusions, he carries them out down to the minutest particulars. For laying down land to grass, and more especially the subsequent management of the pasture, requires great skill and attention, and what to an agriculturist who is inexperienced in laying down land to grass may seem a trifling matter is, if neglected, often the cause of an entire or partial failure. And I am the more particularly reminded of the necessity for this caution when I think of the first and last parts of the following sentence which Dr. Paris wrote in his memoir of the great Arthur Young :- - For it has been said," wrote Dr. Paris, "and 
perhaps not without justice, that the writings of Arthur Young produced more individual harm and greater public good than those of any person who had ever written; but the former inconvenience must always attend the introduction of any new system, of general application, that requires prudence and skill for its successful direction." In other words, many agriculturists seem to have adopted Arthur Young's advice, but did not put it into execution with skill and prudence, and hence inflicted much injury on themselves. But, it may be remarked, though the careful weighing of local conditions is obviously of the greatest importance, both as regards the selection of seed and the proportion of land to be kept in grass, the farmer may, as to the latter point, proceed with considerable coufidence, for errors of judgment as to the proportion of land that should be kept in grass are easily repaired should the error lie in laying down more land to grass than should afterwards prove to be advisable, as grass land, it seems hardly necessary to say, is readily convertible into arable, while arable cannot be converted into grass without a considerable lapse of time, unless the land, which is rarely the case, should have in it an ample supply of humus, and is thus in good physical condition.

There is also another point connected with the future prospects of agriculture to which I would direct especial attention, and that is that the system of farming which must now be adopted in these islands is one highly suitable to the habits of gentlemen, and others who do not feel inclined to rise early and eat the bread of carefulness. The farming of the future, therefore, will carry with it less risk of loss either to the landlord or to those who may choose to adopt farming as a profession, but who are not of the farming classes. And this consideration makes it highly probable that, and to the obvious advantage of our future prospects, much more capital, enterprise, and intelligence will be 
attracted to farming than is now the case. This remark has been suggested to me by the admirable advice given to landholders by $\mathrm{Dr}$. Keith (in his "General View of the Agriculture of Aberdeenshire"), who advises them in general "to be contented with raising grass and green crops, and a small proportion of corn, remembering that a tenant who rises early, and is his own bailiff, or farm overseer, is best qualified to be a corn farmer." To suit the advice to these days, and for the general use of all agriculturists, instead of "a small proportion of corn," we should say the smallest possible proportion of corn.

It must further be considered in this connection that the system of farming to be afterwards recommended as the one most suited to the times, not only, as I have said, carries with it less risk of loss, but ensures good crops of all kinds, whether the seasons may be over-wet or over-dry. For the system provides a deeply-tilled and humus-fed soil, and when you have both you have those physical conditions which make failures in crops an impossibility, for, as has been pointed out by $\mathrm{Mr}$ Hall in "The Soil "- Mechanical texture is of fundamental importance, and many soils owe their value to this property alone, as is evidenced by the high rents obtained in East Kent for soils which contain but little plant food, but which are of uniformly fine texture owing to the fine-grained sand or silt of which they are composed." And if this is the case with such soils how much more so must it be in the case of soils amply supplied with humus, deeply-tilled, aerated, and drained by the agency of the deep-rooting plants which are recommended in my grass mixtures.

In continuing these introductory remarks, I may be allowed to observe that, notwithstanding our present unsatisfactory agricultnral condition, I by no means take those gloomy views of our prospects which are entertained by a large number of my countrymen. Such views, I admit, are perfectly justifiable if any 
attempt is made to plod on with a system which was very suitable to the conditions of twenty years ago (though even then many modifications could have been profitably introduced), but which is entirely out of joint with times when constantly-improving communications are bringing us more and more into competition with cheaper labour and better climates. But, judging by the financial result of my own farming in recent years, I see no reason to despond if we turn our attention to altering our system of agriculture in the direction of limiting our cereals to the utmost, producing them at the lowest possible cost, and introducing improved grasses and other kinds of forage plants. For we have an admirable forage-growing climate, and it must be remembered that the same communications which flood our country with agricultural produce can also bring hither cheaper feeding stuffs and manures, and that these have consequently already largely declined in price in recent years. And if these aids are taken full advantage of, and the necessary changes in our system are carried out, British agriculture will gradually rise, not perhaps into as profitable a state as it occupied in the best of times, but into as secure and satisfactory a position as any in the world.

Finally, it should be considered that the system I have to advocate-one depending entirely upon stockwill be much safer than our old arable culture. For with that we had the maximum of risk, combined with the maximum amount of destruction to the fertility of the soil. And as to that point we have the testimony of the first great meeting of 400 Aberdeenshire farmer's, held upwards of tweuty years ago, who declared that one of the three great causes of their difficulties was the exhaustion of the soil. But the system which I have to urge in these pages will continually enrich the soil, and, what is often of greater importance, improve its physical condition. And it may be well to notice in this connection that the system to be proposed will not 
only suit the times, but also the interests of both the landlords and tenants. Formerly their interests were in a great measure opposed, the object of the tenant being to take all he could out of the land, and the object of the landlord to retain all the strength he could in it; and, with the aid of improperly-composed artificial manures, the tenants have been only too successful in depleting the soil, and, in a large number of instances, after having sucked the orange, have thrown the enpty peels in the landlord's face. But with the system I advocate it will be as much to the tenant's as to the landlord's interest that all the strength possible should be retained in the land, for, in the future, on no other principle can farming in these islands be profitably carried on. And here it may not be uninteresting to notice that similar principles were laid down by $M$. Porcius Cato (born 234 B.C.) in his agricultural treatise, "De Re Rustica." He was asked what was the most certain profit rising out of land. "To feed stock well," he replied. Being asked what was the next point of inportance, he said, "To feed with moderation." Evidently meaning to the extent that paid best, or, in other words, that the farmer should aim at a low cost of production. He also, I may add, laid down that "a good husbandman should be a seller rather than a buyer," which, of course, means that he should breed his own stock, and produce for himself everything that he profitably ean. And it seems hardly necessary to add that the Act which now requires that all imported animals should be slaughtered at the port of debarkation still further enforces the necessity for adhering, as far as possible, to these old Romau agricultural maxims.

I may next allude to a difficulty, with the view of explaining it, and suggesting a remedy. And it is a very important difficulty, and one that has often been wondered at, and-shall I say?-ignorantly wondered at. This consists of the severe resistance to 
agricultural changes, which was well exemplified by the Fnglish farmer who, when some agricultural changes were suggested to him, simply said, "What we knows we knows, and what we don't know we don't want to know." On mentioning this to a landed friend who is interested in agriculture, as well as many other subjects, he said," Why, that is just the case with the landlords in my county, and they don't know, and they don't want to know, nor to trouble themselves at all about the subject." And in Johnston and Cameron's book on agricultural chemistry, it is stated that "the reception of scientific results und suggestions by the agricultural body generally have been so ungracious that little wonder can exist that so many chemists have quitted the field in disgust, and that the majority of capable men should studiously avoid it." And I may mention that when lately making some inquiries relative to the subject of this book at the rooms of the Royal Agricultural Society in London, I was told by the clerk there that never in his experience had a farmer come there to ask a question, or go into an enquiry of any kind relative to agriculture. He should have said that farmers rarely do so. Planters in India, like farmers here, will not read, as both have probably taken to cultivation from a liking to out-door life and an indisposition to any form of intellectual exertion. Then it must be considered that the sharp lads in families are generally sent into law, or trade, or medicine, while the duller are considered to be only good enough for agriculture, or planting, where study, though quite as essential as in other professions, may be neglected without much loss until changing times require important modifications of system. As for our farmers in Scotland, I have often said to some of them that I believe most Scotch farmers would go five miles out of their way to avoid seeing an agricultural improvement. And yet all farmers are ready enough to adopt improvements in the shape of improved stock, 
and agricultural implements and machines; and the explanation of their resistance to agricultural change is that they cannot afford to attempt improvements which are to them of a more or less speculative character, and are afraid of being persuaded to adopt measures which may turn out to be failures. An improved animal they can see, and from it gain an immediate and certain result, and the same is the case with an improved or new implement. But the return from any new course, such as altering their rotation or laying down land to grass, either permanently or for five or six years, requires a considerable time in order to prove the utility of so doing, and, in the case of grass in especial, they are hampered, no doubt, by that part of the old saw as to "making a pasture breaking a man"a saw once most true in consequence of bad and improper seeds and bad methods of laying down, and not so very long ago, but now most ridiculously false, as I shall afterwards clearly show. And now I come to a most important point, to which these remarks naturally lead up, and to which I desire to direct special attention.

I have said that our farmers are afraid to attempt agricultural changes which to them are of a more or less speculative character. I have italicised the words "to them," because the very agricultural changes to be recommended here are precisely those which have been adopted in the La Manche district in Normandy, where the farmers have universally given up cereals for permanent pasture, and this, too, notwithstanding that they had the so-called advantages of Protection. Just enough land is now given up to wheat for household consumption, to buckwheat for the food of pigs and poultry, and to roots, lucerne, and other temporary pasture sufficient for the winter food of live stock. The adoption of this course is universally considered to have been the saving of farmers of La Manche. A similar course would have been the saving of farmers in many parts of these islands. Why, then, were such 
changes of front not at once adopted here? Why did the farmers of Nornandy evidently not consider them to be of a speculative and risky character, while to our farmers they evidently were so? But a reference to our Cherbourg consul's report throws full light on the subject, and we find that he attributes the happy change in La Manche to Government aid in the shape of agricultural schools and experimental farms. Had we had such advantages here, I see no reason to doubt that our farmers would long ago have had recourse to these steps, which were the saving of their brethren in La Manche; and our landlords and land agents, having had equal opportunities, would have readily joined the tenants in aiding to bring about the necessary changes in our agricultural system. But there was ignorance all along the line-a natural dread of embarking on new courses which might prove to be failures, and no means of enlightenment at hand in the shape of Government schools and experimental farms to show how the necessary changes could be best carried out. And has it not been evident to every civilized Government but ours that whereas a question in chemistry or machinery, or of any new method of manufacturing, can be brought to exact proof, and instantly decided one way or other, an agricultural problem not only takes years to work out, but is liable to be extremely difficult of solution owing to the great variety of circumstances and the numerous climatic causes which disturb the results of farming experiments? And seeing that farmers and landlords pay taxes, are they not, therefore, as much entitled to Government aid as science, art, education, or any of the other subjects which are aided by the resources of the State? But it is now time to turn to a consideration of the whole subject before us, and, in concluding these introductory remarks, I only desire to add that if a certain amount of repetition is to be found in these pages, it is because I think it will be useful to those to whom the subject is new. 


\section{CHAPTER II.}

GENERAL PRINCIPLES.

T $\mathrm{N}$ the treatment of almost any subject it is hardly 1 necessary to say that there is generally some leading point, or principle, which mainly goverus it, and which should be constantly kept before the attention. As regards religion, for instance, Confucius was once asked whether it might all be condensed into one word. "Certainly," he replied; "is not reciprocity such a word? What you do not want done to yourself do not do to others." And so, to take another instance, the whole of the agricultural competition we mainly suffer from may be condensed into one expression-the cost of heat, for those who compete most successfully with us are enabled to do so because they obtain gratis from the sun a large supply of what we have to pay very highly for in the shape of clothing, lodging, and fuel; and it is hardly necessary to point out that in India and mild climates, like the best of Argentina, the labourers' expenses are necessarily far less than those of our islands. To turn to the point with which we are more immediately concerned, it may be said that the solution of all our agricultural difficulties, so far as they can be solved by the wit of man, resolves itself into one expression-the cheap production of a good turf. That is the principle which, as I shall show, dominates the whole subject, and that it does so is evident if we consider carefully the following points :-

I. The success of our agriculture depends on the cheapening of production. 
II. The cheapest food for stock is 'grass.

III. The cheapest manure for soil is a turf composed largely of deep-rooting plants.

IV. The cheapest, deepest, and best tillers of the soil are roots.

But before proceeding to prove that a cheaply-created turf is the only solution for our agricultural difficulties, it may be well to notice the solutions that are thought by some to present certain prospects of cure for the unfortunate conditions of our times; for, by first of all disposing of these, we shall be able to fix our attention more exclusively on those factors which alone can set our agriculture on a footing with the requirements of the age.

Only let us have bi-metallism, assert some, and prices will rise, and our old system of farming again become profitable. Only, declare others-and no doubt a very considerable number-let us bave Protection to an amount that would raise corn to a paying level, and all would go well with our agriculture. Only let us have good land legislation, and improved means of securing the interests of the farmer, and our agriculture, with a vastly-increased capital spent upon it, owing to proper security for the tenant having been provided, would again flourish exceedingly. As to the first, we have no means of proving what would occur if bi-metallism was adopted, and there seems to be no prospect whatever of any such general agreement on the subject amongst the nations of the world as would enable any system of bi-metallism to be carried out. And, as for the second point, there seems to be quite as small a prospect of Protection ever being adopted in England within any time worth considering. Nor, unless it were carried out to a very high amount, have we reason to suppose, judging by what has taken place close to our shores, that Protection to a moderate amount could so far favour the farmer as to make grain for sale profitable. For in France there 
is Protection, which gives the agriculturist there $8 \mathrm{~s} 2 \mathrm{~d}$ more per quarter, and yet what have the farmers in La Manche, in Normandy, done? As we have seen, they have given up the growth of cereals for sale in favour of permanent pasture, and now only produce enough grain for consurnption on the farm. Then, as to the third point-land legislation-we have ouly to turn lack to the most prosperous times, to the time when farmers laid out most capital on the land, to see how little the laws can affect the farmer; for in these good days we had the laws of hypothec, which were always said to be so injunous, and we had neither the Agricultural Holdings Act nor the Hares and Rabbits Act. These were the days of high rents, too, and yet one of the largest scale cultivators in the south of Scotland once said to me, "I could make money in those days, but I cannot do so now." Nor, with the present system of farming, could he do so with the aid of all the laws that human folly could devise. Those, then, who hold up bi-metallism, Protection, and land legislation as cures for our agricultural difficulties have little idea of the harm they are doing in dangling false hopes before the eyes of the farmer, and so retarding the adoption of the only practical remedies for the present agricultural situation. For is it not evident that all our attention should be concentrated on the practical remedies within our reach, and which can be immediately applied?

Lastly, in this connection, it should be considered that, whether the remedies held out by bi-metallists, Protectionists, or the legislative cure-mongers come to pass or not, the steps recommended by me will be equally advisable; for if corn growing should never again become profitable, there can be no doubt of the good that will arise from the adoption of the farming system recommended in these pages; and should corn growing for sale again become profitable, then the land laid down to temporary pasture, on a system of not 
less than four years in grass, may have the system shortened to three years, or even to two, and both such lands, and those laid down to permanent pasture, again brought under the plough will be the more fitted for profitable corn growing than ever they were before.

I have said that the production of stock at the lowest possible cost is what the farmer has solely to rely upon, and this, of course, involves the production of their food at the lowest possible cost. Both these facts must obviously govern the farming policy of the future. How, then, can the farmer most cheaply provide food for stock? This, again, depends, of course, as to the way manure can be most cheaply supplied. Now, as every gardener and cultivator well knows, the cheapest and best form of manure is a good turf, for the decaying sod not only supplies the plants with food, but, what is nearly as important, and some might say of even greater importance, provides a good nest, or, in other words, good physical conditions in the soil. And it was on this turf that for so long a large proportion of our agriculture in Scotland depended, when vast quantities of land, enclosed within the last fifty or sixty years, were ploughed up. But in the process of time this resource has become exhausted. It must be again supplied, and this can only be effectively done within a moderate period of time by growing a mixture of large-rooting and deep-rooting plants, managing them well after they have grown, and giving them four to six years' time to form into a turf. When, then, the farmer again ploughs up the land, he will start his rotation with the same advantages which the farmers had when they enclosed and ploughed up old pasture lands; he will so be enabled to produce good crops at the smallest expense, and without the aid of any manure, excepting some artificials with his turnips, and eventually without any when the land has become sufficiently charged with 
humus.* But this process must ouly be continued for four years, during which a turnip crop, taken after ploughing up the grass. should be taken, followed by a cereal crop. Then a root crop should be taken, and the following year the land again laid down to grass with a light cereal crop, and the process of forming a good turf recommenced. Every time that this course is repeated the land will become richer, and the soil more thoroughly and deeply disintegrated by the roots of plants, and therefore more able to yield better and more certain crops, and crops less liable to the attacks of disease; this especially so as regards the turnip crop, which is little liable to finger-and-toe if repeated on the same land only after a long interval. And the formation of this turf will also cheapen the processes of cultivation in two ways, for it is hardly necessary to say that land deeply and thoroughly permeated with vegetable matter is much more easily ploughed and worked; and I have found that if the land is well filled, when laid down, with a mixture of plants which have a large and powerful root system, the conch grasses are extinguished, or nearly so, and the expense of cleaning the land, when again brought under plough, absolutely abolished. $\dagger$ On the rapid creation, then, of a turf composed of plants calculated to leave the largest amount of vegetable matter in the soil, and of plants well able to resist drought, and contribute by their qualities to keep stock in good bealth, the future of our farming, so far as the arable

* Potatoes and turnips have now been successfully grown at Clifton-on-Bowmont farm withont the aid of any manure, except that supplied by the turf (vide Appendix III.)

+ For the last twelve years there have been no weeds worth removing. Subsequent experience has shown me that, in order to abolish the growth of weeds, taking a tnrnip crop after grass is essential ; but, as shown elscwhere, when the farm has once been so thoroughly cleaned that there are no weeds on it worth removing, then the tarmer, if his plans make it expedient, may begin his rotation with oats out of lea instead of turnips. 
portion of our lands is concerned, depends; and it is hardly necessary to say that the same principle applies to the creation of permanent pastures. Having thus stated what I conceive to be the governing principle of the subject, I now propose to advance, in the following chapters, to a careful consideration of the whole important subject of the. best, most rapid, and the cheapest way of creating a good turf; but before proceeding to do so, I wish again to recur to what I have previously alluded-the danger of misapplying the general principle $I$ have dwelt upon, and it is the more necessary to do so because I know of no subject as to which you will hear so many contradictory opinions, and as to which one is more liable, from various causes, to come to erroneous conclusions, seeing that the reckoning to make a farming conclusion correct consists of so many items, that there is therefore a great difficulty in collecting all of them into one view, and a still greater difficulty in estimating their comparative value. A guide to the understanding, then, should be ever near, and I know of none equal to Locke's "Conduct of the Understanding"-a small book of about 100 pages, the most convenient edition of which (Fowler's) may be bought for a few shillings: A careful study of this little volume will keep the mind active to the reception of new ideas, and aid it in carefully collecting and weighing, and re-weighing, all the points that bear upon the present complicated agricultural situation; it cannot be too highly recommended to all those who are engaged in carrying out the changes that are necessary to enable us to profitably manage the land of Great Britain. The situation, indeed, with reference to foreign competition, and agriculture itself, is so complicated that the student might well turn away from the whole subject in despair, unless he follows the admirable counsel of Locke in the section on "Despondency," where, as the reader will observe, his teacher leads to the inference. 
that it is of much more-importance to teach method than to impart knowledge. And if Locke is to be recommended to the farmer, he is still more to be advised for the use of agricultural chemists, who have, as I have shown in my paper delivered at Cambridge (vide Appendix VII.), led the farmer to most pernicious conclusions, because, as Locke puts it, in his section on "Reasoning," "something was left out which should go into the reckoning to make it just and complete."

And, besides the danger of misapplying general priuciples, there are numerous cases where erroneous conclusions are readily come to, as, for instance, that because one seed is cheaper than another it will therefore afford a larger return of grass for the outlay, or that because some of the richest pastures contain certain plants it is therefore most advantageous to sow the seeds of them. or that because you want much clover it is therefore desirable to put down much seed. The whole subject, in short, is a juugle full of traps by which the unwary are only too liable to be caught, and it is therefore important to begin with that attitude of mind, so difficult to attain, wbich enables the individual neither to believe, nor, what is of even more importance, disbelieve anytling whatever without sound reasons for forming a decisive opinion in one direction or another.

Since writing this chapter Lord Leicester has been kind encugh to inform me, in answer to a letter from me on the subject, that he has no objection to my publishing a paper on the subject of the system he has adopted, and which, in priuciple, is exactly the same as the one I have pursued, so far as leaving the land for a certain number of years in grass, and then taking four crops in succession, is concerned. His Lordship's paper is as follows:-

"As many enquiries are made as to the system $I$ adopt in treating poor lands under temporary pasture, $I$ may state that it 
is necessary to carry out the following plan to obtain a satisfactory result. The seed should be selected from those natural grasses that appear to thrive best in the waste places in the locality in which the pasture is to be formed. The seed should be purchased guaranteed as to purity and germinative power. It is most important not to feed the pasture close with sheep during the summer, when the grasses are in full growth, or the more valuable grasses would perish, and weeds and moss take their place; more especially is this necessary in the treatment of permanent pasture. I have, as an experiment, left on very poor soil a pasture down for sixteen years, and I do not find that the herbage has diminished; but there is no doubt that pastures are of most value for the first few years after being laid down, when they are exclusively given up to the feeding of sheep. If the land is to accumulate fertility, and enable four profitable crops to be obtained without the application of any manure, the minimum time nnder which the land should remain in pasture would be six years.

"I believe that it is generally the practice that the first crop on breaking up a pasture should be a corn crop. I think that this would be fatal to obtaining three crops following without the aid of manure. If the land were thoroughly clean, as it should be when laid down to grass, when broken up after being down for several years it will be very foul. It is probable that no merchant can deliver natural grass seeds absolutely free from the seeds of couch grass.* Clover seeds may be obtained free of

* Note by Mr. Hunter, Chester.--The seeds of the true couch grass (Triticum repens) are seldom found in grass seeds, and they should never be present in properly-machined seeds, because they are larger in size than the grass seeds in general use ; and, as two or more conch grass seeds usually adhere together, their removal from other grass seeds is easily effected. The reproduction of Triticum repens is not, however, from sced, but from the creeping underground stems which send up shoots from every joint. Other species of grasses, such as smooth-stalked meadow grass and bent grass, are also known as couch grass, and both these species produce abundance of seeds, which may be either in the land sown down or in the purchased grass seeds. The seeds of all agricultural grasses in ordinary use can be obtained absolutely free from the seeds of couch grass, and all kinds of grass seeds may now be obtained of as high a degree of purity as that of clovers. 
all weeds, but not so grass seeds. The cost of cleaning after a corn crop, when the land is foul, is very considerable, and nearly the value of the crop is consumed in the process; besides, I believe that the constant cultivation that would be necessary would utterly pulverise and destroy the flag* that had been ploughed in, thus reducing the land to its former unfertile state, and precluding the possibility of its producing, without the aid of manure, three more profitable crops. It is a fact well known that very poor soils are injured by constant cultivation and exposure to the sun, though such a procedure is necessary when the land is foul. If a root crop is first taken the pasture should be ploughed in the winter, and cross ploughed in the spring. I have never known a summer when, between March and July -till which month rape or turnips should not be sown-it has not been easy, at a trifling expense, to destroy any vitality that may exist in the flag. The flag should be ploughed in just previous to the sowing of a crop of rape or roots, pressed with a drill-roller, and, should there be any life left in thistles or couch, the extraordinary luxuriance of the rape or turnips would utterly destroy all life; during the time the land was under cultivation not a weed of any kind, except the annuals, the seed of which is in the soil, would appear.

"I think that it is evident that under this system the accumulated fertility of the pasture is not exhausted by the four crops, as I have this year had nearly six quarters of barley per acre, the fourth crop on a forty-acre field, and a considerably better yield than $I$ have obtained on the good land farmed under the fonr-course system; these poor lands after pasture usually produce better crops than the better lands. The root crop would in the first year disintegrate the flag, and prepare the land for a mucl heavier crop of corn than if the corn was sown immediately after the pasture. In fact, in my upinion, a crop of roots preceding a crop of corn on the first breaking up of the pasture is in every way the more desirable process."

The seeds used by Lord Leicester are as noted on the next page.

* Flag is equivalent to turf, 
Seeds for Temporary Pasture on Light Lands.

Cocksfoot

Perennial Rye Grass

Italian Rye Grass -

Timothy

Tall Oat Grass

Galden Oat Grass -
Lb.

\begin{tabular}{c|l}
4 & Meadow Fescue \\
2 & Hard Fescue \\
2 & Tall Fescue \\
1 & Alsike Clover \\
1 & White Clover \\
$\frac{1}{4}$ & Yarrow
\end{tabular}

Lb.

2

1

1

$1 \frac{1}{2}$

1

$\frac{1}{4}$

Total, $17 \mathrm{lb}$. per acre.

The arerage cost of the above seeds, of finest guaranteed quality, is $12 \mathrm{~s} 6 \mathrm{~d}$ to $13 \mathrm{~s}$ per acre.

It will be observed that Lord Leicester says that the minimum time during which the land should remain in pasture is six years, and, with the mixture he uses, I have no doubt that that time would be required in order to accumulate a sufficiently good turf. But if a mixture is used containing a large quantity of cocksfoot and yarrow, and other plants calculated to fill the land with vegetable matter, then I think that a good turf, and one much better than would be obtained in six years from the mixture Lord Leicester uses, could be produced in four years, and with the aid of the following mixture, which I have used with success :--

Lb.

Cocksfoot

Tall Fescue

Tall Oat Grass

Crested Doystail

Hard Fescue

Golden Oat Grass

Rough-stalked Meadow

Grass

\begin{tabular}{r|lr}
10 & Burnet & 8 \\
5 & Chicory & 4 \\
5 & Kidney Vetch & 3 \\
1 & Parsley & 1 \\
2 & Alsike Clover & 1 \\
1 & White Clover & 2 \\
& Late-flowering Red Clover - & 2 \\
1 & Yarrow & 1
\end{tabular}

\section{Lb.}

The cost of the mixture ought to be (prices vary almost every year) from 42 to 45 shillings, and, if the land is left in grass for five years, 
the cost per annum will be about the same as a farmer now spends per annum if he leaves his land two years in grass. As Lord Leicester has pointed out, it is most essential that, on ploughing up the pasture, a green crop should first of all be taken; and I may even go so far as to say that to adopt auy other course would be to ensure a partial, and perhaps a very considerable, failure when the system is first begun, though, as I have elsewhere pointed out, the second rotation may be begun with oats should this be most suitable to the circumstances of the farmer. 



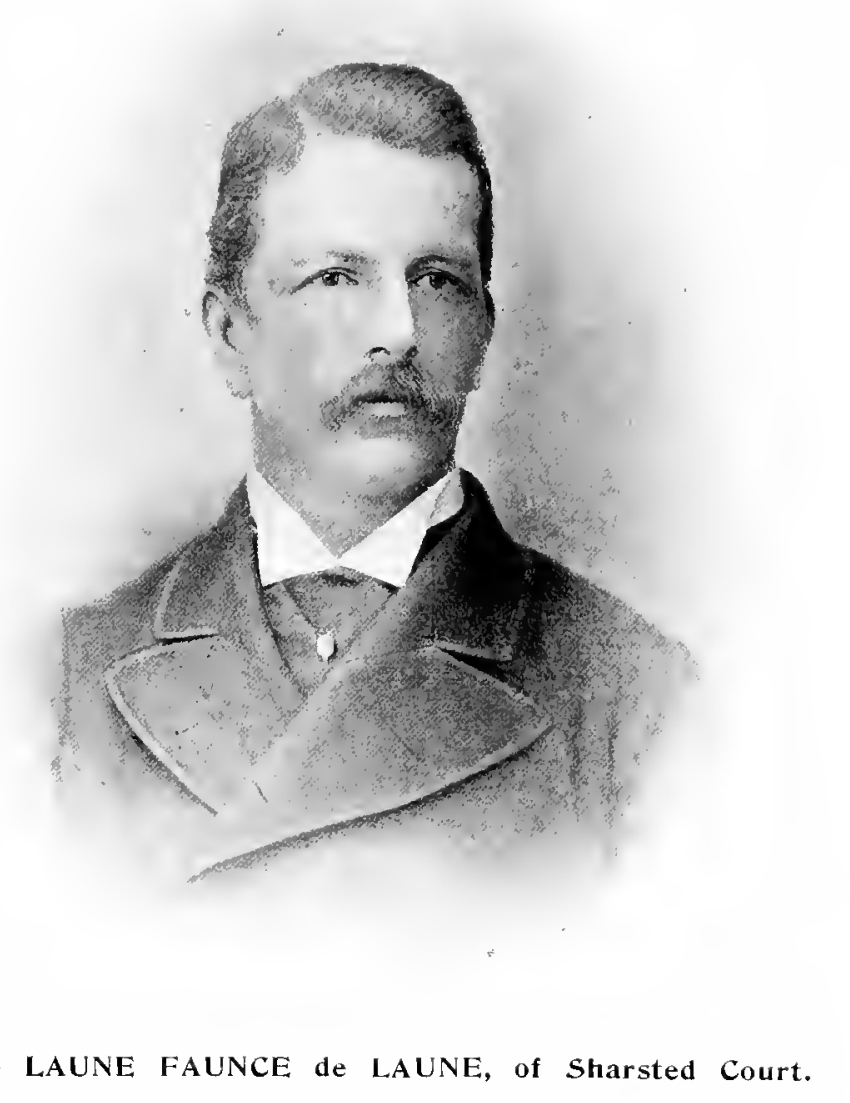

c. de LAUNE FAUNCE de LAUNE, of sharsted court. 


\section{CHAPTER III.}

ON DISINTEgRATING THE SOIL AND PERMLATING IT

WITH VEGETABLE MATTLR.

NE of the most important points to be considered in the whole subject of laying down land to grass is the disintegrating or finely breaking up the soil, and the intermingling with it of a sufficient proportion of vegetable matter, so that the soil may provide a good nest for the plant; for, as Sir John Lawes has well pointed out, it is the physical condition of the soil, its permeability to roots, its power of absorbing and radiating heat, and its power of absorbing and retaining moisture, that is of more importance than its, strictly speaking, chemical composition. This is a sentence, I need hardly say, that every agriculturist should learn by heart, and keep constantly before his attention. and especially in connection with laying down land to grass; for it is in consequence of the neglect of what Sir John has so well pointed out that failures so often occur, and the power to which he alludes of absorbing and retaining moisture is probably of supreme inportance, for however abundant plant food may be, it must be remembered that it cannot enter the plant except through the medium of water. In this connection I may quote the following advice given by my late friend, Mr. Faunce de Laune, to a correspondent, under the following circumstances.

The land, as to which his opinion was sought, was thus described to him :-

"The land is desperately poor land. It has been let lately at $2 \mathrm{~s} 6 \mathrm{~d}$ an acre, and the tenant is leaving; before that it was 
let at $5 \mathrm{~s}$, and seven years after it was let at $20 \mathrm{~s}$, but the tenant failed. The tithe is $7 \mathrm{~d}$ on most of it, and rates at $2 \mathrm{~s}$ in the pound. Not much money is to be expended, and what is to be done ?"

"I advised," he says, "that the land should be frequently harrowed, and in the spring grass seeds, according to my No. 3 Table, for light chalky soils, sown; that it should be harrowed again, and left to Nature for fourteen months ; and after that time it should be lightly fed with bullocks or sheep, the animals, if possible, to be fed with decorticated cotton cake."

The accumulation of rent, rates, taxes, tithe, and cost of seed would amount to about $30 \mathrm{~s}$ per acre, and if the land should be worth $1 \mathrm{~s} 6 \mathrm{~d}$ an acre extra at the end of the year, it would pay the interest on the capital expended. He then adds the following observation, to which I particularly wish to direct attention :-

"How far the accumulation of decaying vegetable matter, whether weeds or good grasses, goes towards manuring the land, and more especially how much it disintegrates the soil, so as to allow the inferior pasture grasses to grow, has not been a subject sufficiently studied; but the more attention and time I give to this subject, the more convinced do I feel that if on very poor land such courses as are described are carried out, Nature, assisted in the inexpensive manner above described, can and will improve the quality of the soil, and this at a less costly rate than by the artificial means of husbandry. Truly, Nature can be aided by supplying the seeds of those pasture grasses which are most beneficial to stock, but then I consider that expenditure should cease on such land as this.

"On a deserted farm in Essex, which I once visited, I noticed plants of cocksfoot and timothy accidentally sown, and growing with the utmost vigour, being evidently supplied with nourishment from decaying thistles and other weeds.

"Farming, as it is practised now, is more often the act of destroying natural fertility than adding to it, and it is therefore no wonder that the land becomes impoverished." 
Mr. Faunce de Laune, elsewhere in his proofs, quotes the opinion of the late Mr. 'T. Carington (Journal Royal Agricultural Society, vol. xv., p. 490), who observes that "no person who has not had experience will appreciate fully the difficulty and tediousness of the operation of converting into l'eally good turf poor strong land which lias been constantly under the plough for generations, and in which every bit of vegetable matter bus been used up by the practice of having periodical dead fallows dressed with lime."

The preceding remarks I have quoted all indicate the really great difficulty connected with laying down land to grass-the want of good physical conditions in the soil, which can only be supplied by permeating it with vegetable matter. The manurial conditions, from a strictly speaking chemical point of view, may be good, but they cannot make up for the want of good physical conditions; and the more I have studied the whole subject by the light of theory, confirmed by practice, the more certain do I feel that the importance of keeping up a good physical condition of soil, though generally recognised, has never been sufficiently acted up to.* My first practical experience regarding this point dates a great many years back, and has ever since been the means of my continually observing and studying the effects of the presence or absence of good physical conditions of soil. I think it would be difficult to find a more thoroughly practical experience than that which I will now proceed to describe.

* The Italians, in some cases, cut gorse and heather, and pile the cuttings between the rows of vines, and leave them (the gorse and heather) to decay, after which the decayed vegetable matter is dug in, in order to supply the soil with humus. It is interesting to observe how man everywhere found that this vegetable matter must be supplied, and that no chemical manures can take its place. This has been equally found by the Italian vine grower, the tea planter and coffee planter of India, and it must every day become more and more apparent to the cultivator of the humus-exhausted soils of Great Britain. 


\section{Importance of Good Physical Conditions of Soil.}

In conjunction with a planter friend in India I once endeavoured to ascertain the consumption by coffee of potash, with the view of seeing how far it was advisable to add it to our manures, and there were accordingly taken with great care two samples of soil-one from the virgin forest land, and the other from land immediately adjacent to it, from which twelve crops of coffee had been taken without any manure being applied to the soil. Thle samples were sent to Professor Anderson, of Glasgow University, and he was asked to spare neither pains nor expense in carefully examining the soils, with the view of seeing how far the cropped soil had been exhausted of potash. The result seemed at first sight to be remarkable; for the soil from which the twelve crops had been taken was found, from a chemical point of view, to be very little deteriorated except as regards lime, which was rather less than in the virgin soil. But the explanation evidently was that the leaves shed from the shade trees and stones decaying in the soil had supplied the small quantity of potash and other ingredients removed by the crops. "Why, then," asked my friend, who had called on the Professor to hear the result of the inquiry, "can young coffee plants easily be grown on the virgin soil while we have the greatest difficulty in growing them on the cropped soil?" "Simply," was the answer, " because the virgin soil is in a fine granular state, and in perfect physical condition, while the soil in the plantation, after having been rained upon, and walked upon, and exposed to the elements, has lost its original fine physical condition." In other words, it had become more or less consolidated, and therefore was a bad nest in which to grow young coffee plants. Here, then, we bave an important practical illustration of what, I feel sure, must frequently be the case-namely, that what is often attributed to manurial deficiency, or, in other words, poverty of soil, is largely owing to physical defects. And if these tell largely on a, comparatively speaking, 
strong shrub like coffee, how much more must they tell on tender-rooted grasses, and how much, further, must such deficiences tell in a climate like ours; which is so much subject to changes which tend to run the soil together, and so injure its physical condition. And if, again, a planted-out plant of coffee is, as we have seen, liable to fail from being put down in a defective nest, how often, too, must grass seeds fail from a similar want of a proper home to germinate in, and how frequently must the tender, newly-grown grass plant fail from the want of suitable conditions for establishing itself in the soil. I think, then, that a little consideration of these points will show that 1 may safely declare, as $I$ have in the beginning of this chapter, that one of the most important points connected with the whole subject of laying down land to grass, either to lie for a period of years or permanently, is the disintegration of the soil, and the intermingling with it of a sufficient portion of vegetable matter, so that, after being disintegrated, it may not readily again run together. The question which naturally occurs is this-How can such conditions be most economically provided? And, first of all, let us take the case of laying down land to permanent pasture.

When laying down land to grass, the usual practice has hitherto been to do so after a crop of turnips, and when the land has, in the course of its previous cultivation, been regularly supplied with farm-yard manure, and so with applications of vegetable matter, and is of a quality that does not readily run together, and so becomes tough and hardened, there is nothing to be said against so doing. But where the land has not been well supplied with vegetable matter, or is of a quality which soon loses whatever physical condition has been imparted by tillage, I have now reason to think, from my own practical experience, that it is decidedly best to lay down permanently, after first of all growing a turf mainly composed of deep-rooting plants, and plants 
which leave much vegetable matter in the soil. For I have found in the case of alluvial flats containing rather heavy land that, after having laid down the land and left it in grass for about eight or ten years, we have, on again ploughing up and laying down, after a course of crops, had by far the most successful takes of grass that I have ever seen. There were two evident reasons for this favourable result. The first was that the soil was well permeated with vegetable matter, and the second that, being so, a thoroughly satisfactory and well aerated bed was provided for the springing of the seed, and the subsequent growth of the young plants. And in the cases previously alluded to, I am satisfied that a still better result would have been obtained had I, when first laying down the land in question, been acquainted with the deep-rooting chicory, burnet, and kidney vetch, and the advantage of using, from a vegetable-matter-creating point of view, a large amount of cocksfoot and yarrow. It may be urged that the process would be a costly and tedious one, and with the old system of laying down with a large proportion of ryegrass, which entailed a falling off of the pasture in the fourth year, this would have undoubtedly been the case; but, with our recent experience here, I have found that land of tough quality, and deficient in vegetable matter, may be loosened, ameliorated with vegetable matter, and deeply cultivated with the agency of roots in about three or four years; and then, after our usual four-course rotation of cereal and root crops, laid down to permanent pasture with satisfactory results. Having thus dwelt upon the importance of disintegrating the soil, and permeating it thoroughly with vegetable matter, before laying it down to permanent pasture, I now propose to allude to the equal, or even greater, advantage of doing so in the case of land to be left in grass for five or more year's, and which is to be again broken up for the winter support of the stock on the farm.

I have been told by a very intelligent gardener, who 
is practically acquainted with the great importance of soil disintegration through the agency of roots, that if he trenches land a foot deep, and takes from it a crop of parsnips, he finds, on taking up the crop, that the land immediately below the part dug is in finer physical condition than the cultivated land above. And this, of course, arises from the fact of the parsnip roots pene. trating, and minutely sub-dividing, the soil, which, from its depth, has the advantage of being largely removed from the action of the weather. And, to give another illustration, we find the same thing in India when the forest is allowed to gradually extend itself into the adjacent grass land, and when the roots of the trees gradually permeate the land below the reach of the roots of the grass plants, and so turn the whole soil to a considerable depth into a beantifully cultivated subject. Or, to take yet another illustration, it may be mentioned that agriculturists in France, to improve certain arable lands, sow on them a mixture of gorse and grass (to be cut for hay) with the view of improving the depth and texture of the soil, which, after the lapse of a certain number of years, is again brought under the plough. Of all cultivating agencies, then, roots stand by far at the head, and it is by applying this principle to our arable lands that we shall at once manure, aerate, and cultivate them in the cheapest manner. All agriculturists recognise this in a general way; but, as regards the cultivation of our lands with the agency of deep-rooting forage plants, it can hardly be said to have been, practically speaking, recognised at all in this country. And I may go as far as to say that, till it is so, our agriculture will never be placed in the position of safety it ought to occupy. I was long ago certain of this, but I never thought that I should be able to prove it to such an extent as I am now able to do; and, as the subject is of great importance, I propose to enter, with some degree of detail, into the particulars of the first experiments made by me as regards laying down poor and 
exhausted land, with the addition of various deeprooting plants to the mixture of grasses and clovers suitable for such soils.

The fields operated on-the Outer Kaimrig, 22 acres, and the Inner Kaimrig, 25 acres-were two of those fields of which there are only too many examples in Scotland, and which never should have been enclosed from the hill and ploughed unless with the intention of at once laying them down to permanent pasture, or treating them on the same system as that previously recommended by me. But they had been managed, and probably for the last fifty years, on the same fivecourse system as the best lands of the farm, but without the advantages of the latter, for the land was so high and distant from the steading that no farm-yard manure was ever applied to it, and the only manure it ever got was just enough of artificials to grow the turnip crop. Everything, then, came down, and nothing went up except the ploughs, horses, and people which were requisite every rotation to more and more thoroughly exhaust the soil, and, worse still, more and more impair its physical condition. What to do with such fields was indeed a problem, and one of them in particular reminds me of Arthur Young's description of some land he unfortunately embarked in, and of which he graphically wrote- "I know not what epithet to give this soil-sterility falls short of the idea-a hungry, vitriolic gravel. I occupied for nine years the jaws of a wolf. It was calculated to swallow, without return, all that folly or imprudence could bestow on it." And the soil of my fields must have been nearly as bad, for one of them consisted to a considerable extent of a poor thin moory soil, while the other only contained a certain proportion of fair hill soil, and to have attempted to treat them on the old system would certainly have been to occupy the jaws of a wolf or a crocodile. I then determined on laying them down to permanent pasture, and they 
were accordingly both laid down in 1890 with a thin seeding of oats. The poorest of the two, the Inner Kaimrig, a field of 25 acres, was sown as follows :-

Cocksfoot

Tall Fescue

Crested Dogstail

Hard Fescue

Smooth-stalked Meadow

Grass

Lb. Lb.

14 Golden Oat Grass - 1

5 White Clover 4

2 Alsike Clover . 2

3 Perennial Red Clover 1

Yarrow 1

2 Birdsfoot Trefoil $\frac{1}{2}$

Total, $35 \frac{1}{2} \mathrm{lb}$. per acre.

The adjacent field, the Outer Kaimrig, 22 acres, I resolved to experiment on, and the mixture used was as follows:-

Cocksfoot

Tall Fescue

Crested Dogstail

Hard Fescue

Smooth-stalked Meadow

Grass

Golden Oat Grass

Burnet

Chicory

Parsley

\begin{tabular}{r|lr} 
Lb. & & Lb. \\
10 & Ribgrass & 1 \\
3 & Yellow Suckling Clover & 1 \\
2 & Kidney Vetch & 1 \\
3 & Lucerne & 2 \\
& Late-flowering Red Clover & 2 \\
2 & White Clover & 3 \\
1 & Alsike Clover & 1 \\
3 & Yarrow & 1 \\
1 & Birdsfoot Trefoil & 1 \\
1 & &
\end{tabular}

Total, 39 lk. per acre.

Both fields were grazed with sheep. The 25-acre field sown showed great signs of inferiority to the 22 -acre field sown up with the addition of the deeprooting plants, and so much so that, after a three years' trial in grass, I resolved to plough it up, and lay down again with a considerable proportion of deep-rooting plants, of which, in the meanwhile, from introducing them on other land in my occupation, I had formed a most favourable opinion. The Inner Kaimrig field was accordingly ploughed up at the end of 1893 , when it was found, mainly, I believe, from 
the quantity of cocksfoot and yarrow used, that quite a thick sod had been formed. In 1894 the land was cropped with turnips, which was a fair crop, considering the poorness of the land. In 1895 the land was again laid down with a thin seeding of oats (which turned out a very fair crop), and the following seeds :-

Cocksfoot

Meadow Fescue

Tall Fescue -

Hard Fescue

Smooth-stalked Meadow

Grass

Tall Oat-like Grass

Rougli-stalked Meadow Grass

Golden Oat Grass

Lb.

\begin{tabular}{l|ll}
6 & Italian Ryegrass & 4 \\
5 & White Clover & 2 \\
4 & Alsike Clover & 2 \\
2 & Late-flowering Red Clover & 2 \\
& Chicory & 2 \\
2 & Burnet & 8 \\
3 & Kidney Vetch & $2 \frac{1}{2}$ \\
& Sheep's Parsley & 1 \\
$\frac{1}{2}$ & Yarrow & 1 \\
$\frac{1}{2}$ & &
\end{tabular}

Total, $47 \frac{1}{2}$ lb. per acre.

As the field was to be cut for hay, Italian ryegrass was added to the mixture. The land was so poor that I had not thought of trying to take a crop of hay from it, but, as my factor wished to do so, I allowed him, as an experiment, to make the attempt. The result for such land was really astonishing, and surprised the various agriculturists who, by my suggestion, visited the field, for a crop of hay was grown which was as good as that produced on the best low-lying lands. There was no weighing machine on the farm, but, from a careful estimation of the stacks, the crop was not less than two tons an acre, and the field yielded a fine aftermath. After such a crop of hay on such poor land, which had never been manured since it was enclosed from the hill some 70 years before, I expected that the field would afford poor grazing, but was agreeably surprised to find that an excellent account of its grazing capabilities was given by the shepherd and steward. 
It will be observed that, in the case of the field from which the hay was taken, the field was cropped with turnips after being ploughed up, and the following year laid down again to grass with a crop, and was not put through our usual four-crop rotation-i.e., a turnip crop, a cereal one, another turnip crop, and laying down again with a cereal crop; and this course was adopted because of the extreme poverty of the land. Indeed, in the case of such poor land it is doubtful whether the land, when again laid down, should be laid down with a crop; but this is a point which will again be referred to when I come to weigh, in a subsequent chapter, the various methods of laying down to grass.

In the year following the hay crop of two tons an acre, the field was grazed with sheep and lambs. And this year (1898) the field (much to my astonishment, after baving yielded such a hay crop, and so much good grazing the year afterwards) has again exceeded my utmost expectations, showing that the manurial effects of the ploughed-up turf is still going on. And I say my utmost expectations, because, in the case of sụch poor land, to which no manure had been added since the artificials supplied with the turnip crop, I certainly expected that the grass would have much declined in the third year.

The adjacent field (the Outer Kaimrig) of 22 acres did so well, in consequenee of the addition of burnet, chicory, etc., that I had determined on leaving it in permanent pasture; but, moss having made its appearance, it was ploughed up at the end of 1895 , and cropped with turnips, preparatory to being laid down to grass on the system previously recommended-i.e., taking first a turnip crop, then oats, then turnips, and then laying down with a thin seeding of oats to lie for an indefinite number of years. On ploughing up the turf, it was found to be so thick and strong that I am now inclined to think that it would be better, in the case of land left 
more than four years in grass, to begin the rotation with rape. When this field, the Outer Kaimrig, was ploughed the second time no difficulty was experienced, as the land had become so ameliorated by the added vegetable matter of the first turf. We have found no difficulty in taking turnips out of grass in the case of other fields. For later information about the Outer Kaimrig field, vide Appendix III.

But I have found, from using chicory, burnet, kidney vetch, and a liberal supply of yarrow, that there are other attendant advantages besides that of disintegrating the soil and supplying it with vegetable matter, for all light land is, of course, very liable to suffer from drought, and all these plants resist drought to a wonderful degree. Of this fact $I$ had a remarkable confirmation last year in the case of a large flat field on the margin of a stream (called haugh in Scotland)-a field interspersed at intervals with gravel beds, the grasses in which, of course, are quickly burned up in periods of drought. Last year there was a very severe drought, and, therefore, an excellent opportunity for testing the value of these plants in dry weather. When the drought was at its height, I, on June 17, 1895, carefully examined the field, and especially the shingly beds on it. On these the grasses and clovers were withered down to the ground, and the clover leaves crumpled in the hand as if they had been scorched by fire; but the droughtresisting plants were green and sappy, though in various degrees. Chicory and burnet clearly stood the drought best, then came kidney vetch, and then yarrow. Of the lucerne plant I cannot speak so positively. Some were dried up and yellowish, while others looked fairly well. I was particularly struck with a plant of burnet. It was touching one of cocksfoot (which stands drought well as compared with other grasses), which was withered yellowish-white down to the ground, but the burnet was as green and freshlooking as a thriving strawberry leaf. And I may add 
that, when on a visit to Oxfordshire the week following, when a bad drought there was at its worst, I found burnet, growing on high dry land, quite green and fresh-looking, though surrounded with grass, bleached as white as that on an Indian plain in the hot season.*

But besides their drought-resisting qualities, two of the plants recommended have valuable medicinal properties, for they keep sheep in healthier condition, and both burnet and yarrow are of especial value in enabling sheep to contend with diarrhœa, while the former is valuable in cases of rot in sheep. Some years ago, when there was much diarrhoa amongst our sheep, I asked a very experienced farmer, who occupied land contiguous to mine, to notice especially how far my flocks compared with his, and I found that I had a much smaller proportion of afflicted sheep and lambs.

Another advantage was also found from using much cocksfoot and strong-rooting plants, and that is that the couch grasses were almost extinguished, and this, of course, cheapened the cost of cultivation when the land was again brought under plough. Lastly, it may be observed that from an experiment in a field on the low-lying land on this property, $\mathrm{I}$ have reason to surmise that chicory and burnet, if used in sufficient quantity (which they were not in my first experiments), are instrumental in lessening moss, or even of almost entirely preventing its appearance, though it is difficult to determine how much this effect is caused by the aeration of the soil which is effected by the strong and deep roots of these plants, or by their causing the ground to be more quickly and completely covered, or by both.

* During the summer of 1898 we had a severe drought, which showed conspicuously the advantage of using drought-resisting plants. I this year observed, what had before escaped my notice, the great drought-resisting power of the late-flowering red clover, which is particularly to be recommended for light soils, and I am now inclined to place it, as a drought-resisting plant, on a level with chicory, burnet, and kidney vetch. 
So far as I am personally concerned, then, I have solved the problem as regards cultivating poor lands without the aid of any manure, and have solved it to the extent of growing, on the poorest land, crops as good, and indeed, I may say, much better, than those commonly grown on the best land; and $I$ have done this, too, after leaving the land only four years in grass, and on a system which is continually improving the fertility of the soil, and deepening the area available for the roots of plants. In the Big Haugh field some drills of turnips were sown without any manure in 1901 and 1903, and answered so well that I sowed a whole field without any manure in 1904 (vide Appendix III.) The system, as the reader will have seen, is an extremely simple one. It consists of creating, with the agency of large-rooting and deep-rooting plants, a good sod, and then relying on it for the manurial (except the turnip manure) and physical conditions necessary for growing two green and two cereal crops, after which the land is again laid down to grass, and the creation of a good sod again commenced. But I must warn the reader, as I have elsewhere done, that this cannot be effected with the aid of the grass mixtures commonly used in rotation husbandry, as with these from six to eight years would be required to form a sod, and even then that would be far inferior to the sod which can be produced in four, or even three, years, with the aid of the mixture I have found to be most efficacious.

This question now naturally arises-Why should I have had to work out my own salvation at my own risk and cost? Why should I not have known exactly what to do when I first took over the farm alluded to? And why should farmers in Great Britain in general not know exactly what to do in order to cope best with the difficulties of these times, and how to do it in the cheapest manner which combines with it the utmost degree of efficiency? The answer to these questions simply is because of the negligence of our Government, 
for there cannot be the slightest doubt that had it had experimental farms and agricultural schools the principles I have laid down, and proved the success of, would long ago have been brought to the notice of our agriculturists and generally adopted. For, as we have seen, the farmers in Normandy, aided as they were by Government schools and farms, seem to have had no hesitation in at once altering their systems in accordance with the requirements of the times, and there can be no doubt that the same results would have occurred here had similar facilities existed for the diffusing of agricultural knowledge, and full and timely information as to all the world-wide causes which would necessitate a complete change of farming system.

But it may be urged that, as we have hitherto done fairly well without Government schools and farms, none are needed now. Such reasoning-and it is a too common course of reasoning-shows how dangerous it is to rely on the experience of the past for lessons for the future, for it is seldom that the whole conditions of the past are exactly repeated, and there is, therefore, always a great risk run of applying to a different set of circumstances conclusions which were once fairly sound for circumstances only partially parallel. In former times no sudden change was required, and therefore the slow processes of improvement which resulted from the example of the most intelligent proprietors and agriculturists answered fairly well. But when a sudden change of front, owing to the wonderfully rapid increase of foreign competition, was required, the knowledge necessary for at once changing our system did not exist, and there was no machinery ready, in the shape of agricultural schools and experimental farms, for providing it; and the result is that while Normandy farmers, as we have seen, have at once been able to reorganise their farming system, and thrive accordingly, we have changed but little; and when we have changed in the direction of laying down land to grass, this has 
often been so badly done, and with so little discrimination, that a vast amount of preventable loss has occurred in all parts of these islands. And this loss has been largely increased owing to the fact that, from the want of proper means of instruction being at hand, the seedsmen themselves were as ignorant of the seeds they sold as were the people who bought them; and hence an enormous loss was inflicted on the purchasers of seeds, as we shall see in a future chapter. The so-called seedsmen were really not seedsmen at all, but merely shopkeepers who sold seeds, of which they either had no knowledge, or none worthy of the name. They ordered seeds from the large seed importers, who took, with little or no enquiry, seeds sent them from abroad, and passed them on, with all their weed seeds in addition.

In this connection I may observe that had such schools and farms existed an immense advantage would have been gained from the instruction they would have afforded, not only as regards fruit and vegetable growing, but also-and this is of even more importance still-as regards the means, now so largely employed abroad, of preserving fruits and vegetables. And I know of no more marked instance of the evil results arising from the neglect of a civilised Government of the material interests of its people than lias occurred in the case of our neglect of what other Governments have done in the way of agricultural education; for, while preserved fruits and vegetables are so largely used abroad, we have actually had, for the requirements of our Navy, to purchase preserved vegetables in France and Germany. My friend, Dr. Voelcker, has brought out an interesting article on this subject in the Royal Agricultural Society's Journal, but neither his article, able though it is, nor any number of articles, can be of any widely-spread practical value till the Government provides an adequate informative agency in each agricultural centre.

I may observe, lastly, that the spasnodic efforts which 
have been made by various County Councils, or which may be made, can never efficiently supply the agricultural requirements of the nation. For whatever efforts may be made by each County Council, paddling its own canoe, as each county does in the way of roads and other matters, will only lead to a number of all-overthe-shop experiments-fairly well-conducted, perhaps, in one county and badly in another, and leading to numerous conflicting conclusions. What, then, is obviously required is that groups of counties of closely similar conditions as to soils and climates should be marked out, and a farm and school establisbed at some convenient centre in each group, and that all these institutions should be placed under an Agricultural Department, which should direct and control the various schools and farms thronghout the country; and, in especial, keep the farmer fully informed, and up to date, as to all the agricultural conditions in the world. But is it not evident that it is only with the aid of education and world-wide information that our farmers will be in a position to alter and re-alter the direction of their efforts in accordance with the requirements of the times?

In the next chapter $I$ purpose going further into details as regards chicory and burnet, and preceding my remarks by some observations as to Arthur Young and his writings, with special reference to his great unpublished and almost unknown work, which now reposes on the shelves of the MSS. Department of the British Museum. 


\section{CHAPTER IV.}

ARTHUR YOUNG, AND SOME OF HIS AGRICULTURAL EXPERIENCES WITH REFERENCE TO CHICORY, BURNET, AND OTHER FORAGE PLANTS.

A RTHUR YOUNG, the widely-known writer on A agriculture and social economy, is described by his friend, $\mathrm{Dr}$. Paris, in the memoir written by him, and which follows the prefaces to Young's greal unpublished work, "The Elements and Practice of Agriculture," as being descended from a respectable family who had resided on their estate at Bradfield Combust, near Bury St. Edmunds, Suffolk, for more than 200 years. He was born September 7, 1741, and as a boy was recognised by his early friends and preceptors as a lad of very superior talents and indefatigable industry, and of the correctness of this recognition he afterwards gave ample proof. In 1758 he was placed in a mercantile house, but showed no tact for commercial pursuits, and he early evinced what his natural bent was by publishing, when at seventeen years of age, a pamphlet on "The War in North America," and also by beginning a periodical work entitled "The Universal Museum." After bis father's death, in 1759, his mother gave him the direction of Bradfield Hall, and in 1767 he began to farm on his own account in Essex. In 1770 he published "A Course of Experimental Agriculture," and between 1768 to 1770 his "Tour Through the Southern Counties of England and Wales," his "Six Months' Tour 'Through the North of England," and his "Farmers' Tour Through the East of England," books which were favourably received, and translated into most continental languages. He published, besides, the "Farmer's Letter to the People of England," the 
"Farmer's Calendar," and in 1774 his "Political Arithmetic." In 1784 he began the publication of the "Annals of Agriculture," which was continued for fortyfive volumes. His "Tour in Ireland" and his "Travels in France," however, are the works by which he is now best remembered. In 1792 he was appointed secretary of the Board of Agriculture, which was then just formed under the presidency of Sir John Sinclair, and in this capacity his services were of the greatest value in the preparation of the agricultural surveys of the English counties. Young's works have appeared in almost every language in Europe, and were translated into Russian by the order of the Empress Catherine, and they seem to bave been almost more appreciated abroad than they were in England. His latter years were attended with distressing bodily afflictions-blindness, and a painful internal malady. He died, we are told by Dr. Paris, on the 12th of April, 1820, at his house in Sackville Street, London, "after taking a glass of lemonade, and expressing himself easy and satisfied." Young was succeeded by his daughter, who died in 1851, and she was succeeded by her nephew, the grandson of Arthur Young, who died at Bradfield, January, 1896, and the Young family is now extinct, after a landed existence there of about 350 years.

Young's latter years seem to have been largely occupied in composing his great unpublished work, entitled "The Elements and Practice of Agriculture," the existence of which few people can be aware of, if I may judge by the fact that no reference to it has been made by the writer on Young in the "Encyclopædia Britannica," from which, I may add, I have taken the list of works given above. Last July I accidentally heard of his work, which had been presented to the British Museum by the widow of Arthur Young's grandson, and at once went to look at it, in the hope that I should find something of value with reference to the subject I am now writing on. I was lasked by one 
of the polite officials in the MSS. Department if I should like to see the wlole work. I replied in the affirmative, expecting to see two or three volumes at the most. After some delay the door was opened, and there was wheeled noiselessly into the room a kind of perambulator on four Indiarubber-lined wheels, on which were ten very large volumes of MSS., written on foolscap of very large size, and none of which, I think, contained less than 500 pages, while several contained more than 1100 . 'These enormous volumes, though entitled "The Science and Practice of Agriculture," really seem to relate to every branch of rural economy, down to the management of bees, the transporting of live fish alive, and the castrating of fish, a practice which seemed to be not uncommon a century ago, and a notice of which I have read in the Scots Magazine, which ruus from 1739. It was, no doubt, on this great work that he thought his reputation would most surely rest, and, considering that its very existence can hardly be said to be known, it is difficult to read Arthur Young's preface to it without a feeling of melancholy. "This work," he says, "which I now presume to offer to the public, has been founded on the basis of fifty years' experience, nuch of the labour of more than thirty years, and travelling to the extent of more than 20,000 miles. It was not originally undertaken with the design of publication, but to form a collection of all those passages which I met with in the perusal of books for my own private use." Shortly after Arthur Young's death an attempt was made to bring out what has been well called his life's work, and it was accordingly submitted to publishers in London; but they were all deterred from undertaking the publication, owing to the great size of the book and the consequent risk of publishing it. A few years later Sir John Sinclair, who was anxious that the work should not be lost sight of to the agricultural world, asked to have it sent to Scotland, believing that Edinburgh publishers would perhaps undertake what their London brethren 
had declined; but no success attended this attempt, and the MSS. were returned to Bradfield, then occupied by Arthur Young's daughter.

Miss Young died in 1851, having appointed as her executor a Mr. de St. Croix, who then placed the MSS. in the hands of his brother Walpole to copy and condense, so that they might be bound and preserved; hence the ten large volumes to which I have alluded, the full title of which is "The Elements and Practice of Agriculture," by Arthur Young, F.R.S., and secretary to the Board of Agriculture, edited from the original MSS. by Walpole de St. Croix, from 1852 to '55. It may be well to mention that the MSS. have been copied in a clear handwriting, and that to each volume there is a table of contents, so that the work may be easily consulted. The original MSS. are also in the British Museum, and one of the officials called my attention to the fact that certain passages had been deleted; but I find, on enquiry, that it is impossible to ascertain whether the deletions were made by the editor or by Arthur Young. They do not seem to be very numerous, if I may judge from a slight inspection I made of one of the bundles of the original MSS. In the Editor's preface it is stated that "the present work, as its title would imply, is not designed to be the practice of Agriculture alone of Arthur Young, but rather a compendium of husbandry from its first dawn to the period of his death in 1819" (which date, I may remark in passing, is a year earlier than that elsewhere given): and in it there are many quotations from, and references to, continental writers on agriculture. As my object was to take notes of points relating to grasses and other forage plants, I confined my close attention to them exclusively, and now propose to give some account of my gleanings from the volumes left by Arthur Young, and shall begin by going at some length into his experiences as regards two important forage plants, chicory and burnet, as to both of which I have had, as 
the reader has seen, most favourable experience on this property.

Chicory (Cichorium intybus) was first cultivated in England by Arthur Young. In 1787 he found it not uncommon in France, and applied to considerable profit by that intelligent husbandman, Mons. Cretté. The produce was so great, and exceeding that of any other plant known, that Young determined to introduce it into England. "Of all the grasses," he says, " it is perhaps the most universal grower if managed and applied with attention." It was probably first cultivated by the Italians. In 1780 it was remarked by a Frencli writer that sheep are very fond of it. It is indigenous everywhere in Lombardy, and is found in the watered meadows freely eaten by every sort of cattle, especially by cows when it is young, and it affords much milk.

Mons. Cretté sows in March, and mows once in the same year. His practice was to dung the land in winter. In the following year he cut thrice, and parts of the land four times. Mons. Cretté used much in soiling, and with great success, for horses, cows, young cattle, and calves. It is greedily eaten by all, and gives good cream and butter. It is not hurt by drouglit. He used $20 \mathrm{lb}$. of seed for rather less than an English acre. No meadows, natural or artificial, can compare with chicory. Lucerne gives only $4 \frac{1}{2}$ tons of hay per English acre, while chicory will give 11 tons. The dry fodder is well eaten, but it is much better given green. Such were Mons. Cretté's experiences of chicory.

In 1788 Arthur Young sowed $10 \mathrm{lb}$. of seed over 5 acres of barley on a good strong wet loam among clover, trefoil, rib, and burnet, and found that the chicory was always eaten by sheep, cows, and fattening bullocks as close to the ground as any other plant in the field. In 1788 he sowed it in drills a foot apart. It produced in green weight in four years 119 tons, ol'

* The old writers, and farmers in general now, always use the term grasses for all plants used with grass mixtures. 
near 30 tons per acre per annum. He had seen chicory flourishing well on clay, loam, sand, chalk, and peat, and has known it sown upon the very poorest spots of poor farms with such success as to prove indubitably the great importance of the plant. If fed off with sheep it would greatly improve the succeeding corn crops. He had known it in the North of Scotland to bear cutting six times in the summer. Pigs are remarkably fond of it. "On all poor lands," Arthur Young writes, "it is of the highest consequence, having no rival. On the very worst soils it is beneficial for sheep, and I may venture to assert that on such a full stock of sheep cannot be kept without it." It succeeds well, he says, sown with barley, or oats, or indeed any other crop. On middling loam he sowed $12 \mathrm{lb}$. per acre broadcast, on poor soils 15 or $16 \mathrm{lb}$., but in drills at 9 inches or a foot apart he found $10 \mathrm{lb}$. to be enough. If sown in drills at a foot apart horse-hoeing he found to be of great value, and this rendered the plant very luxuriant. Chicory he considered to be too succulent a plant to be made into hay on the average of seasons in this humid climate.

Horses, and hard-worked horses, did well soiled with chicory, and without either hay or corn. It produced no ill effect on milk, cream, or butter. In 1792 a Mr. Dunn fed horses, cows, and hoggs with it, and found that the cows' milk was greatly increased. Chicory should be cut four times instead of three in the season to prevent stalks running up.

In 1790 a Mr. Martin said that in the drought of the present season he has nothing on his farm that will keep half the stock that his chicory will, though it is four years old. He fed it with sheep, and highly approved of it. The Duke of Bedford expressed a high opinion of chicory. In August, 1796, $12 \mathrm{lb}$. chicory and $5 \mathrm{lb}$. trefoil were sown on a fallow, and grazed abont Michaelmas for' a month with five sheep an acre. In 1797 it kept six sheep an acre from the second week in April until 
Michaelmas. On $4 \frac{1}{2}$ acres, which were sown broadcast with chicory, ten sheep an acre were kept the first year, 1796, from first week in April to July 22, and then seven per acre to end of October. In 1797 it kept seven sheep per acre, and they had done well. Mr. May, near Ipswich, found chicory the best plant for sheep feed on poor dry soils, and that it did not suffer from dry weather like sainfoin or burnet; and he observed it to grow 7 inches in three weeks, while the two latter plants, on the same soil, in the same field, as near together as possible, grew no more than 4 inches. Numerous evidences were given by Arthur Young to prove that the produce of chicory is at least equal to that of any known plant in this climate. It remains many years in the ground. From his experiments, 62 tons $18 \mathrm{cwt}$. of the green produce was cut in a year. "It will yield a profitable support," he says, "for sheep when the more common plants have almost entirely failed." Chicory hay is as readily eaten by live stock as any other. In the South of Scotland cluver falls off so much in the second, and still more in the third, year that a farmer sowed on a large scale a mixture of chicory, and the plants kept the ground so well that he was disposed to extend the cultivation, but he was deterred by the price of the seed. Chicory is difficult to eradicate when ploughing up, but in no proportion that ought to render it any objection to the culture. With reference to the duration of chicory, ${ }^{*}$ he mentions that in 179012 acres were sown

* In 1893 the Haugh, 28 acres, was laid down, and in the mixture were $2 \mathrm{lb}$. each of chicory and kidney vetch, and $3 \mathrm{lb}$. burnet. The field was ploughed at the end of 1900, and turnips taken in 1901. The turnips were a fine crop, and the land was very clean, though no wceds were taken off. From the fence being shifted on the bank of the Bowmont a narrow strip next the fence was left unploughed. This showed in 1901 a fair proportion of burnet, chicory, and kidney vetch. Two acres of this field were railed off, and let to a blacksmith for his cow. I particularly inquired whether any effect on the quantity and quality of the milk bad been produced by the chicory and burnet, etc. No effects were perceived, but the cow certainly gained in condition from the pasture, and became distinctly fatter. 
with a mixture of plants, amongst which were chicory and burnet, and that in 1800 much chicory was visible. Arthur Young gives many evidences of its suitability for sheep. Finally, he sums up his reasons for advocating the use of this plant as follows :land.

1. The greatness of its produce for soiling on good

2. Its yielding so amply in feeding sheep on all soils.

3. Its being remarkably applicable in the very poorest and most barren chalks and sands.

4. Its forming a most profitalle change on all lands upon which clover fails from too often repetition.

Advantages and Disadvantages of Chicory.-As regards the hay crop the advantages of chicory are-(1) That it effectually holds up the crop, and this not only increases its bulk, but favours the growth of the sinaller grasses and other plants, and also small plants which have sprung later in the season; that (2) when the weather is favourable it quickens the winning of the hay, as the stalks ventilate the cocks; and that (3) the stumps of the flowering stems keep the grass off the ground when the cut grass is in swathe, or in cock. This favours ventilation, and the grass underneath the cocks.

The disadvantages of chicory, as regards hay, are that, if the weather is wet, it retards the winning of the hay, as it holds much water. Another disadvantage is that hay with chicory in it requires to be used the first year. If kept over a year it becomes dusty, and is therefore unsuitable for stock, but there is no reason to suppose that it is unsuitable for stock and farm horses if used during the first year, nor do I know that it is unsuitable for horses in fast work-though $I$ should not recommend it-but this is a point that requires investigation. In the Bank field we found that by stocking in spring from the first week in April to the 20th May, and then shutting up the field for hay, the chicory plant was so far suppressed that no seeding 
stems appeared; in fact, the plant was so suppressed as not to cause any objection as regards the hay crop.

The advantages of chicory in pasture are very great, and there are no disadvantages. The root goes straight down into the soil (in five months I have traced it to 22 inches, and in fifteen months to about 30 inches or more), and the leaves go straight up. The plant therefore neither robs the surface soil nor interferes with the plants in its neighbourhood, which flourish right up to the stems of the chicory. All stock are fond of the plant, and my keeper informs me that hares eat it more readily than any other plant in the pasture. It yields a large supply of food. It is evident that with such plants as chicory and burnet the available area of soil must be very largely inereased, and their use in a field is, practically speaking, an absolute addition to its acreage (vide Chapter VI.)

Let us now turn to another plant, which, from its deep-rooting, drought-resisting, and disease-resisting qualities, for sheep is of evident importance, and see what Arthur Young has to tell us about it.

Burnet (Poterium sanguisorba), we are told by Young, will do on any land, but it thrives best on that which is dry. It is more to be recommended on a sheep walk, and is not only good for spring feed, but as a summer pasture. For the latter it should be kept constantly pared down close, in which management it grows very fast. An experiment by Mr. Anderson is quoted, which shows that on February 14 it was 3 inches high, and it was grazed at intervals every month up to September 29, when the total growth was 72 inches. Sheep are very fond of it. It is early in spring, but not so early as lucerne. Its principal use is for a sheep walk, and espeeially on poor hungry soils. No farmer should lay down for a sheep walk, or for a few years, without sowing a large portion of burnet. Arthur Young did not think the plant valuable for hay. It is spontaneous, he says, in the best spots of many of the 
finest meadows in England. Burnet, when in mixture, is eaten as close as any other plant. Half a bushel (burnet weighs $25 \mathrm{lb}$. to $26 \mathrm{lb}$. per bushel) should be sown in mixture with either trefoil or ryegrass, or with other grasses, for permanent pasture. If sown by itself, one bushel should be used, and it should always be sown broadcast, though, I may observe, he gives no reason for doing so. Burnet is ready for sheep at the beginning of March, and is throughout the year of considerable value. It is not only a preservative against rot, but a cure for it, if only in the beginning of its progress. Cows eat burnet freely, if not old and sticky, and it gives butter an agreeable flavour. In general, all rattle eat it readily when young, and to profit, but not when it is in bent. It is very advantageous for sheep in general. Anderson is again quoted by Young as follows:- "I have put sheep that scoured into a burnet field, and they have soon been visibly benefited. I would earnestly recommend to all farmers to intersperse some of it in every field sown for permanent pasture." One acre of burnet was sown on a part of a field the rest of which was turnips, and the following March fed with sheep, who preferred the burnet, and the acre was thought equal in consumption to any acre of the turnips. It was observed in Staffordshire that as a meadow grass it preserves the hay from overheating in the stack. Hay of meadows which contain a considerable portion of burnet comes out of a fine green colour, while other hay, equally well made, but without this plant, overheats, and comes out quite brown.

After having written on chicory and burnet at great length, Arthur Young proceeded to remark on "some other plants which may be found to answer as artificial grasses." None of these seem to have met with much attention in England, but as Government experimental farms will probably be started here, as they have been by every known civilised Government except our own, it may be useful to note what Arthur Young says regarding them. 
Vicia cracca.-Found in the watered meadows of Lombardy. I think it an excellent plant, and not diffienlt to enltivate. Cattle eat it.

Vicia sepium.-Shoots earlter in spring than any plant eaten by cattle, which are remarkably fond of it. From experiments made, the dry fodder got from an acre amounted to nearly $4 \frac{1}{2}$ tons. It is recommended by Mr. Anderson-apparently the same Mr. Anderson previously quoted by Young.

Vicia lathyroides.-Sown in spring and autumn, and assists in banishing fallows.

Melitutus officinalis (the common melilot).-Readily eaten by sheep, and abounding in poor land. Grows well about Paris, Chantilly, and other places in France on the worst soils, and to a great height. Cultivated in Germany for horses. Relished by all stock.

Astragalus glyciphillys (the wild liquorice),-Yields an abundant crop. Spreads much by the roots in the watered meadows of the Lodizan. Cows eat it freely.

Medicago falcata (yellow medic).-Affords an abundant pasturage. Loses little weight in drying.

Ornithopus perpusillus. - A plant introduced into England from Portugal in 1793. All animals fond of it, but it made a poor show, and suffers from frost.

Trigonella fcenum gracum.-Cultivated in the Bolognese in preference to clover.

Trifolium muliens.-Much cultivated near Naples.

Coronilla varia.-Abounds in the Lodizan in sry and watered land.

Hedlysarum coronariun.-A Arabians introducel into Calabria. It grows 5 or 6 feet high. No use in England.

Luthlyy latifolia (everlasting pea).-A perennial plant, and good for hay. Cultivated with advantage by a Mr. Tempest. Si)wn for cattle, and recommended by Hartlib middle of 17 th century.

Bunias orientale.-Arthur Young gives a promising account of this plant. "Cultivated in Middlesex" on a dry gravel, the produce was apparently greater than that of any other grass. 
Cut several times in the year. Eaten with good appetite by cows, horses, pigs, fowls, and ducks.

Melilstus Siberica.-Grows with great luxuriance. Eaten greedily by all stock. A plant very highly deserving a mort extended culture.

I now turn to a point which was evidently of great importance in Young's times, and which, in consequence of grain growing having become unprofitable, has again become of great consequence, for the expensive turnip crop is not a crop that pays of itself, but is largely of value because of the grain crop that follows. If, then, grain is low in price, it is of obvious importance to replace the turnip crop as far as we can by some cheaper crop that will aid us in earrying our flocks through the winter and spring, and, as an additional reason for doing so, I may point to the well-known fact that turnips, when used exelusively, are an unsuitable food for sheep, as they are productive of disease-so much $s$ that it is almost proverbial amongst shepherds, who all know that the more turnips we have the more sheep disease. And I may mention that when there was once a great failure in the turnip crop in this neighbourhood the sheep never did so well. I met with a remarkable instance of the danger of using turnips freely in the case of a farmer to whom 1 let a farm which harl for some years been in my own hands. He complained to me that he had met with a great loss amongst his sheep, and yet when the farm was in my hands the death-rate had been very low, and, in going into the subjeet, I found that it had arisen evidently from his changing his flock at the end of autumr to an exclusive diet of turnips. So that by turning our attention to other food for winter and spring I feel sure that we shall not only feed our flocks much more cheaply, but keep them in far healthier condition. I now proceed to quote Young's experiences of the value of what in his time was ealled rouen-or aftermath saved for spring use. 
Young speaks highly of this practice, and "scarcely knew a person who tried it that ever gave it up." He had had twenty-five years' experience of its value. Writing in 1771, he says that it was a common practice in Dorsetshire, where the flockmasters placed their great dependence upon it. In 1776 he found that Mr. Maurice, in Shropshire, kept every year 30 acres for the support of his cows and sheep till February. Young found the system in practice in Suffolk. By Mr. Green's account in 1785 he kept the aftermath of some of his meadows for his dairy of twenty cows, and also for sleep and lambs, till his cabbages are done in March, never stocking the ground from mowing till that time. In a letter from a Dr. Parry we are told that he considers rouen to be "a cheap and valuable resource, which never fails except when it is covered with snow. Last year my shepherd was fully convinced that four acres of very indifferent upland rouen given to my ewes and lambs saved at least 3 tons of hay. Rouen supplies a sort of intermediate food between the dry and the green." The custom was pursued in Lancashire and Leicestershire by some of the best farmers, who asserted it to be the best and most certain spring food yet known. The autumnal and spring shoots mix, and furnish together more nutritious food than either taken separately. A pasture thus preserved is depended upon as the sheet anchor in preference to turnips, cabbages, or any other species whatever of what is called spring food. This kept grass gives more milk than turnips. Where turnips fail, it is of immense value. A shilling spent in rouen goes as far as a guinea spent in turnips. My sheep, writes Arthur Young, in consequence of this aid, have not known a liungry belly in March and April. An acre of rouen is more valuable than most acres of turnips, which had suffered from the summer drought.

As an experiment, he put 22 ewes in 7 acres in one field, and 10 hogg rams in 3 acres of another, and these were kept from November to May without any other 
food, and no sheep on my farm did better. This was above three per acre, and for two months the former had their lambs at their side. I had rouen on the better part of my farm, apparently of near double the value.

The winter of 1794-95 was uncommonly severe, frost being of the hardest and longest ever known. His experience under these circumstances was that rouen was as safely to be relied on as in the milder winters during which it was tried. Young complains of turnips as being expensive and liable to be injured by frost, and he might have added that, unless unusual precautions are taken, sheep swallow grit and earth with them, which are both injurious. * The Earl of Exeter, we are told, sells all his turuips to his neighbours to be fed with sheep, and relies on his rouen, and has known no redwater, or other distemper, in his flock since he has adopted this practice. In his paper on the subject, Arthur Young gives numerous evidences of the value of rouen. In Tweeddale, on the sheep farms, part of the pasture is hained (preserved), and also in other parts of Scotland, Mr. Young says that he has depended upon it principally for the support of 200 sheep. The grass is much more early and productive in spring if, after mowing, no stock is turned in till spring. The dry herbage shelters the young grass shoots in spring, and thus promotes their growth. Rouen was also adopted in Herefordshire. A Mr. Knight is quoted as observing that, if leaves are eaten off shortly after mowing, the roots are deprived of their nourishment, and the plants consequently vegetate weakly in the ensuing spring. Aftermath left to rot on the ground is a good preparation for the next crop of hay.

But in one part of the country the practice of saving growing grass for future use was much further extended,

* A tenant farmer once took one of my grass parks, and sent in some prime hoggs, and some of them sickened and died. My shepherd examined the stomach of one of them, and found grit in it, which had been swallowed when eating turnips which had not been sufficiently cleaned. 
and Arthur Young, under the heading of fog, observes that it is a term given in South Wales to the growth of the whole year kept till the ensuing winter and spring, a practice commonly found nowhere else. On dry sound land that will not poach, the whole crop of grass is kept in Cardigan without being mown or fed; stock of all sorts fed in depth of winter withont any other food, and always in excellent order. It kills moss, and much improves the pastures; nor will an acre of the best hay support so much cattle as one acre of fog. The grass is much improved by the quantity of seeds that fall.

As regards improving a meadow, Young recommends that it should be harrowed and top-dressed with earth or road-scrapings, and then sown with winter tales and white clover-a practice, he says, known in Norfolk 150 years ago. Very good results have been obtained from it, and the seed may be sown as late as the middle of May.

I now turn to Young's experience as to laying down land to grass. There is much said in favour of sowing grass with rape, to be fed off by sheep. In Yorkshire Colonel Vavasour laid down with buckwheat sown in the end of June, and harvested end of September, and this plan turned out to be very successful. At Felthorpe, in Norfolk, buckwheat was considered superior to any other crop in which to sow grass seeds. It affords good shelter, and, being late sown, gives a good opportunity for destroying weeds. Young laid down a field to grass (chiefly burnet) in 1769, which did very well, though the buckwheat was a very great crop-49 bushels an acre. Buckwheat he considered the best crop with which to lay down, because it was not exhaustive sown thinly, and yet from branching, and size of leaf', joins so close at the top that the young grasses have plenty of room; they are quite sheltered from the sun in a drought, and, being sown so late as June, and even part of July, time for much tillage is afforded. Clover does 
well with it. Young records that an agriculturist (Dalton) had sown grass seeds with beans, which were preceded by barley, and which again was preceded by turnips, and the results were so successful that he preferred this to all other methods. In order to note the advantages of sowing grass seeds with oats as against doing so with wheat, Young on one occasion sowed 10 acres with $10 \mathrm{lb}$. of chicory and 4 or 5 bushels of cocksfoot per acre. Five acres were sown with wheat and the rest with oats, and he found that the cocksfoot did much better with the wheat. He speaks highly in favour of sowing up land with wheat in the beginning of September. He quotes an agriculturist (Goring) who "once sowed grass seeds amongst turnips in the spring, and the sheep trod them in with their feet as they fed off the turnips. No corn was sown with them, and they flourished beyond any other.' After quoting other opinions, Young thus concludes his section on laying down to grass :-

"Upon the whole of these mast valuable articles of intelligence, and combining them with the result of my own extensive experience, I am decidedly of opimion that the best method is to sow the seeds alone in August; that the next best method is to sow them with buckwheat* in July; after these I should prefer rape in August on soils not apt to biud with treading; then comes the sowing with wheat early in September, and the last and worst method is to sow them with spring corn."

I next proceed to give some notes of what Young says of some grasses. Of crested dogstail he remarks that in one of the very best fields on Romney marsh, and famous for fattening sheep, it is third in a list of plants (Price "On Sheep," p. 276.) A Mr. Knight is quoted as

* Young elsewhere praises buckwheat highly as an ameliorating crop, and one which increases the production of wheat. It deserves more attention than it has received. It takes little out of the soil, and he quotes Tusser as observing that "it is to the land a comfort or muck." It is good for fattening swine and poultry, and as food for horses. 
observing the herbage of some fields he possesses, and which are remarkable for fattening sheep, are composed almost entirely of crested dogstail and ryegrass, and a small quantity of white clover. Young thus concludes his remarks on crested dogstail :-

"Authorities in favour of this grass might be greatly multiplied, but I do not give them, as only one writer has said anything against it, and that is sufficiently answered by its being found in great quantities in the most famous grazing lands in the kingdom."

Taking into consideration the controversy about ryegrass that has raged in recent years, Young's remarks on cocksfoot are very interesting. Sir Mordaunt Martin, he tells us, found this grass much more profitable than ryegrass. It grew in midsummer when everything else was burnt up. It was cultivated in Norfolk and Suffolk with great success instead of ryegrass. Young recommended it widely in consequence of its earliness, largeness of produce, and yielding an ample rouen (aftermath). He quotes a Hampshire farmer who, in 1812 , asserted that since cocksfoot had been substituted for ryegrass 100 additional sheep had been kept on his farm of 240 acres. When recommending cocksfoot, Young says "that the exclusive attention that has been given to ryegrass has proved in a thousand instances most prejudicial."

Yarrow. - Young highly recommends this plant.

Holcus lanatus.- - He has often heard it abused. It is bad for horses, no doubt, but does well for everything else. It is best for sheep, but bad for hay. When the good grasses cannot be procured, recourse should be had to it.

Burnet, once called Saxifrage (Poterium sanguisorba). Young again alludes to this plant, and mentions that it was recommended by Worbage in 1675 , especially for cows, as it gives the best butter and cheese. There are large tracts of the finest parts of the Southdowns upou which burnet forms half the indigenous pasture. 
Agrostis stolonifera-Creeping bent, black couch, fiorin (socalled in the Irish language), joint grass (England).-Young devotes no less than 24 pages to this grass, as to which there were many disputes ; but, for reasons that will be subsequently given when recurring to the subject of this grass, it would, I think, be unprofitable to quote what he says regarding it.

Poa trivialis.-Young is of opinion that this plant never flourishes in a dry soil.

Avena elatior. - Young sowed this grass largely, but gave it up in favour of cocksfoot. Elsewhere he says tall oatgrass is good, but must give place to cocksfoot, which much exceeds it.

I next turn to what Young says as regards seed and seed mixtures, and desire particularly to call attention to the fact that he especially insists on this pointnamely, that " whatever sort is used, thick sowing is essential to success."

In the case of a poor wet loam on a clay marl bottom, he advises cocksfoot, crested dogstail, Yorkshire white (Holcus lanatus), timothy, a portion of chicory and burnet, and by all means (the more the better) yarrow.

The quantities of seeds he recommends, if sown alone, are-

Cocksfoot, 4 bushels per acre.

Crested Dogstail, from 20 to

$30 \mathrm{lb}$.

Yorkshire white, 4 bushels. $\quad$ Burnet, $15 \mathrm{lb}$.

If in mixture, one-seventh of the above weights and measures are to be used. Yorkshire white, he adds, is, for mowing, good for little, and for hay chicory should be excluded, as it takes too long to dry. He next gives the mixtures which he thinks suitable for the undermentioned soils, and I would call attention to the fact that from all of them ryegrass is omitted.

For clay.-Cocksfoot, dogstail, foxtail, trefoil, Yorkshire white, timothy.

Loam.-White clover, Yorkshire white, fescue, foxtail, dogstail, poa, timothy, yarrow, cocksfoot. 
Sand.-White clover, yarrow, burnet, trefoil, cocksfoot.

Chalk.-Yarrow, burnet, trefoil, white clover, chicory.

Peat.-White clover, dogstail, cocksfoot, foxtail, fescue, timothy, yarrow.

As regards the subsequent management of the pasture, Young's remarks show that there were great differences of opinion as to the mowing or grazing the first year. He mentions that Sil Charles Middleton hays the first year, and uses aftermath for fattening sheep and lambs, giving some oilcake, and folding off as for turnips. Another writer quoted says that nothing but having a good coat of dung to put on before winter can justify mowing.

As I notice in the Field of 'Sept. 12, 1896, attention has been called to the value of loppings of trees as food for stock, I may mention that Arthur Young has a section on "Browsing," and gives many instances of the practice of cutting faggots of branches in full leaf and preserving them for winter use. Fir branches were used in this way in conjunction with hay. The fresblycut branches were strewed about the field. After the sheep had picked off the green matter the wood was then used for firing. Elm branches were considered to be the best, and then poplar. Oak branches were considered to be good for this purpose. Young observes that a great saving of hay was effected by this practice.

I have now, I think, quoted from Arthur Young's great work most of those points which seem to me to be useful and interesting, but I cannot conclude the chapter without expressing my admiration of the wonderful combination of qualities he possessed, and which enabled him, and justly so, not only to impress and influence his own countrymen, but also all the most civilised peoples of Europe. Such a union of zeal, indefatigable industry, ability, perseverance, and undaunted courage it is indeed very difficult to find united in any man. One instance of the last I cannot help quoting from Dr. Paris' Memoir 
(previously alludec to), in which we are told that "in his second journey to France he set out alone, but he had not proceeded more than 100 miles when his mare fell blind; not, however, being discouraged by this incident, he travelled with her 1700 miles, and brought her safe back to Bradfield." But, besides the strength of character shown by the instance quoted, he evinced the greatest candour of mind in chronicling his own mistakes, and severely animadverting on them, which he sometimes does to an amusing extent. Altogether, he leaves on the mind a most agreeable impression, and a feeling of confidence that in his various writings he has accurately and fully recorded the agricultural experiences of his times. 


\section{CHAPTER V.}

LAYING DOWN LAND TO GRASS, AND THE TREATMENT OF THE PASTURE.

A S Byron has well said, there is nothing so difficult A in poesie as a beginning, except perhaps an ending, a remark which applies to many subjects, and I confess I am rather at a loss to know how far to go back in my treatment of this subject. Those who wrote on agriculture long ago, and undertakings connected with it, generally seemed to aim at a remote start, and we accordingly find that the writer of the article on agriculture in "The Complete Farmer, or a General Dictionary of Husbandry in all its Branches," the fourth edition of which was published in 1793, claims for the art of agriculture " the precedence of all others in point of antiquity, it having been the sole employment of our first parents in the delightful garden of Eden," and continues by observing that "Adam instructed his children in this most necessary art, both by example and precept." And it may also be noted that Mr. William (afterwards Sir William) Dugdale went back a point further in his book on "Draining and Imbanking "-work which he traces to a Divine origin, seeing that-and he supports his statement by quotations from Genesis-the Creator began with these most necessary undertakings, having found that nothing could be done with the world till it had, first of all, been drained and embanked. While another writer, when alluding to Poa aquatica (reedy sweet grass, or meadow grass), has suggested that, from its feeding qualities, it was probably on this grass that Nebuchad- 
nezzar subsisted when he was turned into the wilderness, and so carries back his observations on this plant to a remote probable use of it. I think, however, that the reader will rest satisfied with my having, in the preceding chapter, alluded to some of the works of those who lived in the last century, and begin the subject of laying down land to grass by referring to an interesting paper which appears in the appendix of Dr. Keith's "Agriculture of Aberdeenshire."* But before doing so, it may be interesting and useful to allude to some opinions as regards ryegrass which $\mathrm{Dr}$. Keith quotes from Dr. Anderson's "Original Report of Agriculture in Aberdeenshire."

After remarking on the value of ryegrass in the case of rich lands, Dr. Anderson observes that

"Upon poor soils it is perhaps one of the worst grasses yet known. Its leaves there are not more abundant than those of dogstail grass ; and so dry and rigid that cattle are not fond of it. Its stalks spire forth very early, and, being unmixed with leaves, they are tough as wires, so as to be disrelished by all beasts; and are all allowed to get into seed, when they become brown and sapless, and good for nothing. On poor fields no practice can be so bad as that of sowing ryegrass. It extirpates all other grasses, and this is worse than any of them."

It is not a little remarkable that this grass, which, for poor lands at least, was so justly condemned in former times, should be a grass still so much used in Scotland on poor lands; but this, of course, is to be attributed to the ignorance of the farmers as regards other and more suitable grasses, and Dr. Keith, though he does not, as I strongly do, recommend the starting of Government experimental farms, goes far in this direction when he suggests

"That a publication which might, by the Board of Agriculture, be rendered both a cheap and useful one, is much wanted,

" "A General View of the Agriculture of Aberdeenshire," by George Skene Keith, D.D., Aberdeen. 1811. 
not only in this county, but in every county in Great Britain. This is a book, neither voluminous nor couched in learned phrases, which would point out all the bad practices in the different districts which ought to be abandoned and avoided, and all those good practices in husbandry which ought to be universally known and generally innitated."

Let us now turn to the short paper to which I have alluded, and which, we are informed by Keith, was contributed by a gentleman of Aberdeenshire, who did not wish his name to be made known.

The paper in question is entitled "Observations on British Grasses," and, though only consisting of six pages, contains as full and exact an account of the principles by which we should be guided when laying down land to grass as could be desired. He begins by animadverting on the poor qualities of ryegrass, and then describes the results which follow from its use when laying down light lands to grass. He shows how, in the second and third year, the clovers and ryegrasses decline; how the blanks are filled with weeds and bad grasses; and how, at last, the whole land is covered with a thick, but coarse, herbage; and how any attempt to arrest this watural course of things by top-dressing will only end in disappointment and loss. He then proceeds to observe that in all such cases there is a deterioration of the soil, which gradually consolidates, as is evidenced by the flattening of the ridges and the firm texture of the soil when turned up by the plough. This solidity, he observes, is very different from the tenacity of clay, and resembles more that which is observable in flower pots whose earth has been kept too long unchanged. He then dwells on the disappearance of vegetable matter from the soil (the evils of which I have previously remarked on), and comes to the conclusion that such light lands, if worthy of cultivation at all, should either be brought under the plough more frequently, and refreshed with manure, or laid down with some of the hardiest grasses. $\mathrm{He}$ 
then enumerates various grasses which, in his opinion, would be suitable for such soils; but I do not propose to dwell upon the kinds mentioned, as my object is to call attention to the fact that the principle of putting down a mixture of grasses suitable to the soil, and without any admixture of ryegrass, was recognised so many years ago, and that attention was also called to the decline of vegetable matter in the land, to the consequent consolidation of the soil, and its being turned into a bad physical medium, or a bad nest for the plant. But why should this consolidation of the soil not have been prevented by putting down a mixture of plants which would at once permeate it to a great depth, and furnish it with abundance of regetable matter? It is singular that a writer so evidently intelligent as the author of the paper should have failed to point to the obvious solution of the difficulty, and it is also remarkable that Arthur Young, though he used a mixture calculated to effect this purpose when he recommends chicory, burnet, and the free use of cocksfoot and yarrow, should have failed to point out their great value in disintegrating and aerating the soil, and filling it with vegetable padding. After carefully examining his work, from which I have taken so many extracts, I can find no allusion to the important physical effects arising from the use of these plants. But the reader has now heard probably enough of this branch of my subject-enough, I trust, to, impress him with those principles which should guide him in the selection of plants, either for temporary or permanent pasturesnamely, that a selection should be made which will at once provide the most food for stock, keep it in healthy condition, and maintain a good physical condition of soil. I now pass to a consideration of the various methods of laying down land to permanent pasture.

My readers will remember that in the previous chapter I have given, from Arthur Young's great work, his own opinion as to the various methods for laying down land 
to grass, and also those of other agriculturists whose systems are recorded by him. My present system here, after the trial of several different methods, is to lay down in spring with a light seeding of barley or oats*a system which I have found to answer well, both as regards grass and the requirements of the farm, and which, I may observe, was condemned by Arthur Young as being the worst; while the late Mr. John Wilson, Berwickshire, for year's adopted a system, to which I shall afterwards allude, which is very different from any practised elsewhere, as far as I can learn. After carefully weighing the merits of the various systems, I have come to the conclusion that, in consequence of the variety in both soil and climate, and the varying circumstances and requirements of the farmer, no general rule can be laid down as to which is the best method, and that this should vary according to the circumstances of each particular locality. And here I am left to grope in the dark, for, from the nonexistence of the Government experimental farms which ought to exist in each locality, there is really no means of writing on the subject in a satisfactory manner; in other words, there is no means of proving what courses are most suitable for the varying climates of these islands. For instance, after studying the methods recommended by Arthur Young, I am strongly inclined to agree with him in thinking that to lay down with

* With a seeding of slightly under a bushel of barley we have obtained a heavy crop-or, at least, a very good one; and that, too, without injuring the grass, which would hare suffered had the crop been obtained with the aid of a full-seeding of barley. In the first case a number of barley shoots are thrown out from each stem, and this has the effect of letting more light into the ground, while, in the event of the crop being laid, the shoots on the upper side of the prostrate stem remain more or less erect, and certainly raised above the ground, and thus do not lie on the grass. A heavy crop of barley from a full seeding gives many stems, with few shoots to each, and both stems and shoots are of a weak character from crowding; hence, if laid, the crop goes down like a thatch on the young grass, and, in any case, the young grass plants are over shadowed, and thus weakened in character. 
buckwheat, after taking a crop of winter vetches, would probably be the best plan; but though this would evidently be, from Young's experience, a suitable plan in the South of England, I have no means of knowing whether it would be profitable to lay down in the South of Scotland with this plant. At almost every point, then, connected with this subject the writer is sure to be confronted with difficulties arising from the waut of that information which might, and should, be provided by local experimental farms. But though the means for writing positively for the various localities do not exist, it is clear that success may be attained in various ways, and it will be useful to enumerate them here in one group.

There are, to begin with, the methods of Arthur Young, who, as we have seen in the preceding chapter, approves of sowing the seeds aloue in August as being the best method; secondly, of sowing them in July with buckwheat; thirdly, with rape in August, on soils not liable to bind with treading; fourthly, of sowing them with wheat early in September; and lastly, the worst method in his opinion, sowing them with spring corn. Of the agriculturists whose opinions are quoted by bim one sowed with beans, which he found more successful than any plan he had tried; while another sowed his grass seeds amongst turnips in the spring as they were fed off by sheep, and found that the grass "flourished beyond any other." Then there is the system successfully practised by the late Mr. John Wilson in Berwickshire for many years, and of which he gave a full account in the North British Agriculturist of January 21, 1885. His original practice was, after turnips, to sow up with 2 bushels of Koenigsberg tares, 2 bushels of oats, half a bushel each of Italian and perennial ryegrass, $4 \mathrm{lb}$. each of alsike, white clover, and trefoil, and $2 \mathrm{lb}$. of cow clover. His later practice was to diminish the ryegrass, and substitute 4 or $5 \mathrm{lb}$. of cooksfoot and timothy. He cut the crop 
before it reached the full blooming stage, and made it into hay. In the case of very rich land he omitted the tares, and sowed 3 bushels of oats, and cut the crop for hay whenever they were fully shot, and before the grain had formed. The late Mr. Faunce de Laune's experience was-and a very extensive experience he had-that grass may be grown equally well with or without a crop, and after any crop, excepting clover, for, sown after clover, he found that the grass most conspicuously failed. I now turn to a consideration of that most important of all points connected with laying down land to grass-the subsequent treatment of the pasture.

Some years ago, when discussing the whole question of grass with a farmer who is most skilful in laying down, and still more so in managing, his pastures, he said that the management of the pasture is even of more importance than the selection of the seed and the preparation of the land. And this remark I am particularly anxious to impress upon all those who are inexperienced in laying down land to grass, because it is from the too common, careless treatinent of young pastures that such a number of complete and partial failures occur. And farmers who have hitherto been in the habit of only laying down grass to lie for a year, or two years, and treating it in the way such grass is usually treated, are too apt to treat in a similar manner land laid down to permanent pasture, or that is to lie for five or more years before being again ploughed. And it is of the more importance to dwell on this point, because the mixtures which ought to be used for five or six years' lays, or for permanent pasture, are so much more expensive than those usually sown in land to lie for a short time.

It is of great importance to leave a long stubble when cutting corn with which seeds have been sown in spring, to shield the young plants from frost and sun, and cold winds; also to prevent the topping of the 
olovers and grasses which, of course, bleeds them, and should this topping be followed by frost-by no means an impossible thing in some seasons-serious injury would be caused. One of the worst errors usually committed by farners who have sown out either with or without a crop is to turn lambs into the young pasture the moment there is a supply of grass for them. By doing so they acquire a slight gain, which is sure to be followed by a loss that far outweighs the trifling advantages obtained; for many of the young grass plants, having obtained but a slight hold of the ground, are pulled up by the roots (I have watched this cheering process), others have their roots ruptured, and so are easily thrown out by frost, while others -very small plants from seeds that have germinated late-are injured, and perhaps stamped out of existence if the weather is wet; others, again, are injured by the urine of the sheep, and by being lain upon; and, lastly, all the plants are injured by being cropped at that early period, as the root growth is checked, and they are therefore hindered from establishing themselves as deeply in the ground as they otherwise would. For all these reasons, then, it is obvious that, as a rule, stock should not be allowed to enter a young grass field during the year in which the seed is sown. If, however, from any cause, the barley should be short and scanty, while the growth of the grasses and clovers is luxuriant, and likely to be injured from the grass being laid; or, as in the case of the Bank field experiment (vide Appendix III.), where it was desired to restrain the growth of the chicory and the strong-growing grasses, then the field may be lightly grazed with lambs and calves after harvest, without any bad effect. The next error, and one which is often committed, is that of failing to carefully roll the land in the beginning of winter and the spring following, for, in consequence of this neglect, the plants are liable to be thrown out by frost, and also to suffer from drought in the spring. 
And when I say carefully I mean that the land should be rolled with careful regard to the weather and the state of the land, which is very apt to be too damp or too dry, and I have had land of my own injured by being rolled when in too damp a state. Having the land well rolled enables a shower of rain to be much more effectual than it would otherwise be. When the soil is unrolled, and therefore loose, the water of a shower would quickly evaporate and be easily carried away by the wind, whereas the rolled soil would cause a shower to go much further in supplying the plants with moisture. Rolling would sometimes have the effect of keeping plants alive which would otherwise die. When my steward mentioned to a farmer visitor the importance of rolling, he said: "Oh, we have no time for rolling." This shows the want of agricultural instruction.

A third, and very important error, is commonly committed by overstocking the land early in the spring following the year in which the grass seeds have been sown, for Sinclair "found, on repeated trials, that cropping seedling grasses before they had produced flowers had the effect of retarding and weakening the aftergrowth of the plant for that season very much." And on referring the point to Mr. Carruthers-botanist of the Royal Agricultural Society of England-he replied as follows:-

"The after-growth of grasses depends on the strength of the plant, and especially on the hold it has on the ground. Up to flowering the plant is making itself above and below ground. Flowering and fruiting are exhaustive processes, and while this goes on the plant does not extend itself; but the after-growth of the plant will be improved by its growing as long as it can up to flowering."

And it is for these reasons that I prefer to take a crop of hay in the first year, and this seems to be the usual practice, if I may judge by the opinions collected on 
the subject by the Royal Agricultural Society, and which appeared in the Journal of April, 1888. Of the agriculturists consulted (of whom I was one) sixteen mow the first year, three do not mow, one may mow first year, one mows sometimes, and one mows and grazes alternately.

But besides the obvious advantages of not cropping the seedling grasses either in the autumn or spring* following laying down, and, allowing the plants to begin to flower before cutting them for hay, there is another great advantage from adopting this course, as it gives a good opportunity for re-seeding vacant places; for, however carefully land may be laid down, it will be found that there are always many vacant spots, and though those may not seem, at first sight, to amount to a considerable area, let any one take a rake and some seed, and do the work himself (as I have), and he will soon find that they are far more than one would be inclined to suppose.t It is true that these gaps would eventually be covered over, but it is important to remember that our fields, like our minds, are liable to be filled with weeds if vacancies are left for their growth, and I consider it, therefore, of great importance to re-seed vacant places, though they be only a few inches wide. To do so, I have found, will cost about a shilling an acre for labour. Two women, or boys, should go together. One should have a rake and scratch the ground, and the other put down the

* The subsequent adoption of the Bank field mixture (vide Appendix III.) calls for a modification of this remark in consequence of the use of such a large proportion of the strongest grasses, which would, if not kept back by grazing to a late period in the spring, give a coarsc hay. For the benefit of the subsequent grazings, and the pasture generally, we have also found that a crop of hay, if more than two tons an acre, is a disadvantage. We have also found that by grazing in spring the chicory is so suppressed as to cease to be an objection in the hay crop.

+ The steward at Clifton has sown several large fields without any vacancies, but these were fields of light soil where the seeds were less liable to fail. 
seed, and these operations should be carefully superintended. When the Duke of Wellington was once asked by Lord Mahon (afterwards the Earl Stanhope) what was the principal cause of the success of his campaigns, the Duke replied-"The real reason why I succeeded in my own campaigns is that I was always on the spot. I saw everything and did everything for myself." Farmer's should apply this anecdote to themselves, and the proprietor, too, if he wishes his fields to be so well filled with good grasses that there is no room for weeds and bad grasses; and do not let the latter rely on his farm manager or steward, or both. I have both, but, on looking into the work on one occasion, I found that, partly from carelessness and partly from the wind having sprung up, the seed was largely landing, not on the vacant spots for which it was intended, but on the adjacent grass. For later experiences on this subject, vide Appendix III.

Should it not suit the farmer to take a crop of hay the first year he should be careful not to stock his laind until the plants have begun to throw up their flowering stems, and, if possible, should only stock with young cattle. The vacancies should still be sown up in the spring, for though some of the young plants would probably be destroyed many would survive.

I have remarked on the importance of filling up the ground with the view of keeping ont weeds and bad grasses, but there is another enemy which must not be lost sight of-moss, which will speedily reappear in the vacant places, and spread from them. And as regards moss, it is the same in the case of earth in a pot shonld the plant which occupies it be in an unhealthy condition, and so not only decline above, but make little root growth below. The soil thus soon becomes solidified, or, in other words, loses its good physical condition, and then it begins to grow moss. And the springing up of moss in a field is really owing to the exposure of the land to the elements, and, besides, to its not being 
sufficiently kept open by the roots of plants. I was particularly struck with this fact in the case of a field iu an alluvial flat which I had laid down to permanent pasture. On one side of the field there was a knoll of about six or seven acres, and, after sowing the whole field with the grass mixture suitable for such land, I added, to the land of the knoll, burnet, chicory, sheep's parsley, ribgrass, yellow suckling clover, and kidney vetch. These not only aerated the land, but filled it up closely with plants, and the result was that the poorer land of the knoll surpassed the land of the rest of the field, and was quite free from moss, which soon began to appear on the land sown with the ordinary mixture suitable for the soil. This is a point to which I shall again allude when treating of the quantity of seed which it is desirable to sow, but I may add here that I was lately struck, in the case of a very mossy field, by the effect thistles have, evidently from their aerating the soil, in suppressing moss. On our hill pastures the barest places have always most moss, and such bareness is really owing to the almost exclusive close grazing of pastures with sheep. It seems to me quite clear that by increasing cattle and diminishing sheep you would certainly lessen moss, and much improve the pastures, as letting up the grass has a tendency to keep the ground more open, and the land therefore better aerated (vide Appendix III.)

We have seen that it is advisable, for the reasons given, to take hay the first year, and that in the second the pasture should be grazed with young cattle. In the third year it should be grazed with young cattle in the spring, and some sheep may be put on in the autumn if it suits the plans of the farmer, and in the fourth year with either sheep or cattle, though if with the former it is advisable to let the grass have a good start in the spring, both for the sake of the pasture, and with the view of getting the most food from it in the season. We are often told that the requirements 
of the farmer impel him to manage his pastures badly, but, from my own experience in the case of an excellent tenant of my own, I can see that it is more often owing to a mixture of carelessness and want of skill that pastures are mismanaged, and the tenant in question, from his attention and judgment in judiciously shifting his stock, has at once more stock and more grass on his land than any farmer in this part of the country. I was particularly struck with this point in the case of one of my grass parks, which was let to him for two consecutive seasons. It consisted of grass in the third and fourth years-the proverbially trying fourth yearand yet he kept more stock on it than has been kept on my best old pastures, which were let to tenants, while all the time the field had an ample supply of grass.

I turn, lastly, to the consideration of the subject of the management of pastures, so as to obtain from them the greatest amount of winter and early spring food, so that we may be able to maintain our flocks in the most satisfactory manner, and with the smallest possible assistance from root crops; for, as Sir John Lawes has pointed out, if we deduct the litter and food required for horses, grass land can produce more stock than arable, and it must always be remembered that the cheapest food we can grow for stock is grass. The last is a fact that seems to have been long ago perceived, as the reader who has read the last chapter will remember, and the bearing of it on our present agricultural conditions, and the deduction that should be drawn from it, are of the utmost importance.

I have said, in a previous chapter, that the rapid production of a good turf is the key to all our agricultural difficulties, so far as these can be solved by the wit of man; but it must be considered that this method of solution can only be fully successful if the cheapening of production, which we can alone attain through the agency of turf, is developed all along the line. I 
have shown how, by the agency of turf, in the case of lands to be kept in arable, good crops of roots and cereals may be produced at the lowest possible cost. It remains to show how grass lands should be managed so as to aid still further in lessening the cost of production by reducing the area of the root crop, and therefore the area under plough, to the lowest possible limits. This is a point our ancestors successfully grappled with, and we can only do so, as far as I can see, by following their example. Let us, then, revert to the methods they practised, and which have been alluded to in the last chapter, and one of which, as we shall see, is still practised in South Wales.

And, first of all, let us consider the value of what, in Arthur Young's days, was termed rouen-a word which I have been unable exactly to trace; the nearest approach I can find to it is roughings or rowings (aftermath), a south-country word given in his "Provincial Glossary" by Francis Grose: London, 1811which seems to have been particularly applied to aftermath preserved for spring use. $A_{s}$ it is a short word, it may be as well to use it, and more especially as it will probably be even more used in the future than it was in Arthur Young's days.

The practice of relying on rouen for spring use seems to have been a very ancient one, and I may remind the reader that Arthur Young speaks highly of it after an experience of twenty-five years of its value, and that he states that he "scarcely knew a person that tried it who ever gave it up." He complains of turuips as being expensive, and liable to be injured by frost, while after his experience of the winter of 1794-95, which he speaks of as the hardest ever known, he was able to declare that rouen was as safely to be relied on in severe winters as during the milder ones in which it was tried. The grass, it was pointed out by another agriculturist quoted by Young, is much more early and productive if, after mowing, no stock 
is turned in till spring, as the dry herbage shelters the young grass shoots, and thus promotes their growth; and after reading the numerous evidences and opinions quoted by Arthur Young, in his great unpublished work, I caunot have the slightest doubt of the advantages of the system. By adopting it as far as we can we should at once keep our flocks in more healthy condition, save money in feeding them, and add to the stock-producing area of our farms by reducing the number of our cart horses.

But there is another ancient practice which Young, as we have seen, alludes to under the term fog, given, he states, in South Wales to the growth of the whole year kept till the ensuing winter and spring-a practice, he tells us, "commonly found nowhere else." Stock of all kinds, he says, were fed on it during these seasons, and the system was found to kill moss, and improve the grass by the quantity of seed produced; he further states that an acre of fog will support more cattle than one acre of hay. I have made special inquiries, and have obtained the following information from reliable sources:-

"The custom you refer to," writes my informant, " is still in existence in parts of Cardiganshire, Carmarthen, and Pembroke. It is generally termed 'fogging the land.' Owing to the proverbial wet weather prevailing in South Wales, many farmers, rather than run the risk of a poor hay crop, prefer leaving certain fields ungrazed from July till about February, when the milch cows are turned thereon, then some young cattle generally follow, and the horses get the last bite. Much of the grass having withered, with some green intermixed, it is considered very beneficial as preparatory to the stock being turned into green pastures. The system has also its disadvantages, as, by allowing the grass on the land, it tends to destroy the most tender and nourishing grasses, and ultimately the quality of the pasture becomes very much coarser. ${ }^{*}$ The fogging of land

* This seems to show that the land should unly be hained once, say, every four years, as an occasional haining could, I should say, do little harm to the smaller grasses. 
certainly tends to destroy moss, and many of the fallen seeds will, of course, vegetate. Mr. Young is right with regard to one acre of fog being of more value than one acre of hay, provided it is a mild winter, with but little frost and snow, and in a sheltered locality."

I would bere observe that the reader must not suppose that the disadvantages alluded to by my correspondent must occur always; on the contrary. they need never occur in the case of well laid down pastures, and I had an interesting proof of this when, on the 7th of June, 1884, I visited, in company with some landlords and tenant-farmers, Mr. Faunce de Laune's pastures at Sharsted Court. In one case my frieud had allowed a pasture in its fifth year to grow up, intending to cut it for hay, but for some reason or other he changed his mind, and turned sheep into it, which were kept on the pasture in the autumn, winter, and spring following. The result extremely astonished one of the oldest, most experienced, and intelligent graziers present, who could not at all account for finding on the 7 th of June such clean, level, close turf, with grasses as fine as those on a lawn, following on the letting up of the pasture the year before. But the explanation is simple. Ordinary pastures, if so treated, would certainly show deterioration, because they usualiy have a considerable proportion of weeds and inferior grassesholcus especially. Were such pastures, then, allowed to flower, and then grazed with sheep, they would pick out the good kinds of grasses, and reject the bad grasses and weeds. Then the large grasses, being thinly distributed in the ground (as they commonly are in most old pastures), would assume a coarse and hassocky appearance, and the stems, in consequence of the large grasses being thinly distributed, being very strong, would not be closely eaten by sheep. But when (as in the case of Mr. de Laune's grass under consideration) the land is full of large grasses they keep each other in subjection, or, in other words, fine; and 
as there are no weeds nor bad or coarse grasses to be rejected by the stock, the whole pasture, or what may be called the standing crop of hay, is grazed evenly over during the course of antumn and winter; on the arrival of spring you have a clean field, and up at once starts a fine and even pasture. The Bank field (vide Appendix III.), now tour years old, shows conclusively that as fine a pasture as could be desired may be formed from the largest grasses. In this case $14 \mathrm{lb}$. cocksfoot, $7 \mathrm{lb}$. each of tall fescue and tall oatgrass were nsed, and only one small grass, Poa trivialis. When such a combination is used you have all the drought-resisting advantages of the large grasses, with the increased vegetable matter from their large roots when the pasture is ploughed up, and by grazing the pasture late in the spring-say, up to the 15th Mayyou can produce as fine hay as conld be desired.

Another great advantage from letting a pasture up at intervals of several years is, as we have seen, that not only is it re-seeded, but the moss is destroyed, should there be any present. The latter is a point of great importance, and one which I have closely studied, and I am now satisfied that moss is usually cansed by the consolidation of the surface soil, which commonly takes place where pastures are continuously and closely grazed, and not merely, as is commonly supposed, from chemical poverty. I was particularly struck with this in the case of a small enclosure $I$ had made in a field with the view of testing the proportions of plants in a young closely-grazed pasture in which moss had made its appearance, bnt when the grass was let up in the enclosed plot the moss soon disappeared, or nearly so, and a close observation showed that much of it had been dragged up by the rising grass; I could see it in some cases hanging to the seeding stems. The soil of the enclosed plot soon became comparatively soft, while that of the field was hard and, comparatively speaking, consolidated. I have also observed the same 
point in the case of pleasure grounds, part of which had been hayed from a great many years past, while part had been kept as lawn. The latter was full of moss, while the forner had hardly any, and the surface of the lawn was hard, while that of the hayed land was soft and open. Whenever, then, moss appears in a pasture it would seem to be advisable to let the pasture up in the summer, on the Welsh fogging systen, and put on stock either in November or in the early spring. Many of our hill pastnres-in fact, most of them-are heavily afflicted with fog, and if, say, 50 or 100 acres were annually treated on this system, I think that the whole pasture could then be gradually improved, and that at no further expense than that of fencing off, with moveable fences, the pasture to be operated on.

It has been pointed out to me-and, indeed, it is sufficiently obvious-that in the case of pastures preserved for winter and spring use there would be a certain risk from snow, and, were the pasture composed of short grasses, this might be serious; but by using liberally the seed of the tall grasses this risk would be much reduced, and it is a risk that the farmer might easily provide against by keeping some hay in reserve for such a contingency. But in any case, it should be considered that the risk of relying on foggage for winter and spring use would certainly be less than relying on turnips, which are not only liable to turn out a poor crop, but to be much injured by frost, and which, besides, are certainly not nearly so suitable a food for sheep as foggage.

In concluding this chapter, I may observe that I can see no better way of fighting our two great enemies, turnips and cereals, thail by the adoption of a. system of rouen and foggage, combined with a liberal use of oilcake whenever the prices of it are as low as they are at present. And in abolishing cereals as far: as possible, and only growing enough for consumption on the farm, it is cheering to think that we 
shall be carrying out the principles of political economy, and all those trading laws which are so constantly pressed on our attention. We shall produce, what we can produce, most cheaply, grass, and the inhabitants of other climates-warmer ones with cheaper labourwill produce for us all the grain we require.

From a national point of view, I need hardly say that I have written the three preceding sentences with a feeling of pain; but if the hidebound politicians of the day persevere with their principles of political economy in the face of a steadily-decreasing rural population it is impossible to write otherwise. I am, of course, perfectly aware that what made an Empire, and what alone can maintain it, is a strong, healthy, and numerous rural population; and were Great Britain ruled by a wise Emperor the first thing he would do would be to levy such an amount of Protection on agricultural products as would fill again the cottages which have been so steadily emptied in recent years. My system of farming will indeed check the decline of the rural population, and even cause a moderate increase of it; but it must be aided by Protection if we desire to raise the numbers of our rural population to what they once were. 


\section{CHAPTER VI.}

FORAGE PLANTS.

66

NEVER revert to the past" seems rather a whole1 some maxim. When I first heard it, many years ago, I thought it a very strange one, but I do not do so now, as a more extended experience has shown me that, by referring to the past, you are often liable to fall into a trap rather than into the hands of a trustworthy guide; for there are two great dangers in relying on the past action of our predecessors-the one, as I have previously pointed ont, that it is difficult to find any set of present circumstances exactly on all fours with those of the past; the other, that what has been done in the past may have been done, not on sound principles as to what was best to be done, but for some other reason altogether, and that the action taken on that reason may be partially wrong. When, for instance, I began to turn my attention to farming here, I was struck with the fact that the farmers usually began their nineteen years' leases by a heavy application of lime, though this is easily washed out of the soil, and should be applied little and often, and I was told that small applications were of no use. But $I$ found on inquiry that in Durham, where eight-year leases were usual, the farmers limed every eight years, while in Gloucestershire the custom was to lime in small quantities every four years. But the explanation of the action of the Scotch farmers really was that, while they thought they were carrying out the results of a well-found experience, they were simply blindly working by a custom which 
arose from the length of the lexases, and the desire of the farmer to get the largest benefit from his expenditure. But his action, resulting from his imperfect reasoning, was wrong, for he would have obtained a greater benefit by applying his lime at two different periods of his lease. There, then, is an instance of the so-called practical experience of the past, which is too often a custom which has arisen from erroneous reasoning. And when we come to consider the apparently inexplicable circumstance that the farmers of this country should still prefer a dear and inferior grass to a cheaper and better one-ryegrass to cocksfoot-for their temporary, and often for their permanent, pastures, we shall see still greater reason for subjecting the experience of the past to an extremely close scrutiny, for it either may or may not be a really well-founded experience. In the case of the preference for ryegrass shown by most farmers, the cause, as far as I can learn, seems to be mainly a purely accidental one, and the subject is of such interest and importance that it may be well to quote in full a note on the point, which has been sent to me by Mr. James Hunter, the well-known agricultural seedsman of Chester. It is particularly interesting, I think, from the concluding sentence, which tells us that had not Mr. Faunce de Laune gone back to Sinclair to find out the truth we should probably be pretty much where we were twenty years ago. Mr. Hunter's note is as follows :-

"The grass seed pamphlets of the leading seed merchants in England, up to 1882, may all be said to have derived their information from Lawson's 'Agrostographia ;' and, as an excessive use of ryegrass was there recommended, the error extended to all the trade pamphlets. Lawson obtained his information from Sinclair, but Sinclair did not recommend the use of much ryegrass.

"In 1825, when Sinclair had finished his great experimental work for the Duke of Bedford, and had published the second 
edition of his book, he became a nurseryman at New Cross, near London. Shortly afterwards Mr. Charles Lawson, of Edinbnrgh (Lord Provost of Edinburgh in the early sixties), went to New Cross Nurseries, under Mr. Sinclair, and no doubt learned the subject of the grasses there. In 1833 Mr. Lawson, having returned to Edinburgh, and being engaged in the seed trade, wrote his paper on grasses, which appeared in the Quarterly Journal of Agriculture (see the volume I have sent you, page 714). As ryegrass was almost the only grass seed dealt in at that time, and other species were diffeult to obtain, Mr. Lawson seems to have arranged the quantities in his tables to suit the circumstances, and so he recommended the use of no less than from $12 \mathrm{lb}$. to $30 \mathrm{lb}$. of perennial ryegrass per acre (with other seeds) for laying down land to permanent pasture. But that was not Sinclair's teaching. At page 243, second edition, 'Hortus Gramineus Woburnensis,' Sinclair gives his selection of seeds for permanent pasture, and although there is a certain vagueness, on account of the quantities being chiefly given in bushels, yet it is fair to assume that in Sinclair's opinion the proportion of ryegrass to the other species in a pasture should be about one to twenty. Lawson, however, recommended that ryegrass should compose from one quarter to one half of the whole seeding. The 'Agrostographia,' published by Lawson, continued to recommend the excessive use of ryegrass, and the teaching of this work was adopted by the seedsmen of Great Britain without question. At that time the Lawsons supplied the English seedsmen with their grass seeds, and, in fact, controlled the trade in natural grasses. Indeed, it may be said that they not only supplied the other seedsmen with the seeds, but also with the ideas and information in reference to the subject. Thirty years ago the writer was three years warehouse manager in the grass seed department of Lawsons, and is consequenlty acquainted with the facts.

"To Mr. Lawson is due the credit of creating sources of supply for the various grass seeds, but it is a pity he did not revert to Sinclair's teaching as to the limited use of ryegrass as soon as the other grasses could be freely obtained. If Mr. de 
Laune had not gone back to Sinclair to find out the truth, I fear we should still have been pretty much where we were twenty years ago.

"J. H.

"July 27, 1896."

And here it is important to observe that Sinclair not only restricts the use of ryegrass to about one-twentieth of the mixture he thinks advisable for permanent pasture, but recommends its use, but in small proportion, for alternate husbandry. And for the latter he advises a mixture containing no less than three-fourths of cocksfoot, while hard fescue, meadow fescue, roughstalked meadow grass, tall oat-like grass, timothy; ryegrass, and clover should make up the remainder of the mixture, or, to use his exact words, "should be used in smaller proportion." But neither Sinclair (though he alludes to the superiority of cocksfoot to ryegrass as being less impoverishing to the soil, and affording a greater quantity of vegetable matter when ploughing up) nor my late friend, $\mathrm{Mr}$. Faunce de Laune (though the latter did allude to the question of the disintegration of the soil as a subject which had not been sufficiently studied), have at all attempted to regulate the mixture they propose with reference to the effect of the roots of plants in keeping open and deeply aerating the soil. And, as we have seen, to find any account of such a mixture having been advised in the past we have to go back to the last centuryto Arthur Young, who had recommended the use of plants that would have this very important effect on the soil, thoing I may observe he did not allude to this, either because he thought it too obvious to be worth mentioning, or because he had not taken the point into consideration.

I have now to observe that if the conclusions I have arrived at are correct-i.e., that a grass mixture should consist of the seeds of plants, some of which are of deep-rooting and drought-resisting character, so as at 
once to draw support from the lower strata of the soil, supply food when other plants dry up in a drought, and deeply disintegrate the soil, and permeate it with vegetable matter; if some of the plants should, besides, be of a kind especially calculated to promote the health of the stock, and also act as a preventive against disease ; and if the greater part of the mixture should consist of grasses calculated to give the largest possible amount of produce, it is evident that all the existing mixtures for permanent pastures inust be largely reconstructed, so as to meet, as far as possible, the above-mentioned requirements. And seeing that, from the existing agricultural conditions, temporary pastures will in future be allowed to lie from four to six years, it is equally evident that alternate husbandry mixtures should be composed with the same ends in view, and so should pretty closely resemble those used for permanent pasture. For laying dowu, then, to permanent pasture, and in the case of land to lie from four to six years, I now use much the same mixture, with this difference, that in the case of the latter I omit meadow foxtail, and, in the case of light lands, timothy too, as it is considered unsuitable for dry lands. As to the proportion of grasses, plants, and clovers that should be used, I am far from saying that the proportions I have used are the best. On the contrary, much more experience will be required to show the proportions that should be used for our varying soils and climates, but I feel sure that the principles on which my mixtures are founded are sound, and that the resnlts from them on this property have been most satisfactory, and, indeed, in the case of the poor lauds, the results have surprised me, and also farmers of great experience. I may here mention that during my long experience I have used a great variety of mixtures, and with varying degrees of results, but I do not quote any of them, because I do not consider that they were founded on those principles which I now see should 
be adhered to when laying down land to grass. Two of the mixtures I have sown in 1895 were used for the two poor land fields to which I alluded in a previous chapter, and $I$ also give the following, which was used for a field of very different character, on the low-lying land on the Clifton Park portion of the estate, some five miles distant from Clifton-on-Bowmont. In the case of the last, then -the Longshot field, a deep, strong soil on a low-lying alluvial flat-the following mixture, on the 25 th of April, 1895, was sown with a thin seeding of oats:$5 \mathrm{lb}$. each of cocksfoot, meadow foxtail, and tall fescue; $7 \mathrm{lb}$. of meadow fescue, $4 \mathrm{lb}$. of tinothy, and $1 \mathrm{lb}$. each of wood meadow grass and rough-stalked meadow grass; $2 \mathrm{lb}$. each of white clover, alsike, and perennial red clover, kidney vetch, and lucerne; $3 \mathrm{lb}$. of chicory, $8 \mathrm{lb}$. of burnet, $1 \mathrm{lb}$. of sheep parsley, and $\frac{1}{2} \mathrm{lb}$. of yarrow. The field-one of 15 acres-was, in 1896, cut for hay, which amounted to 36 tons 14 cwts., or nearly $2 \frac{1}{2}$ tons per acre; and the aftermath, grazed with lambs, was an excellent crop. Two trenches were cut in the field to a depth of about 3 feet, and on September 11, 1896, in company with my friend Dr. Voelcker, I carefully inspected the land in order to estimate the depth to which some of the plants had penetrated. The results were particularly interesting as regards chicory, which scemed to have a profound contempt for the very hard pan, which we found at about 14 inches below the surface, and which was about 10 wenes to a foot in thickness, and was so hard that a powerful man with a sharp spade had to use great force to break it open whon we were tracing the descent of the chicory roots, whicl had passed straight downwards without any deflections. As the seed was only sown in April, 1895, it is interesting to find that the roots can go through this hard pan into the soft subsoil, which was a sandy clay, in such a comparatively short time; and we noticed that, in passing through the pan, the strong roots of these plants, notably the chicory, had succeeded 
in disintegrating the apparently impenetrable pan.* Altogether, we estimated that the roots had gone down about 30 inches. The burnet and kidney vetch roots had gone down about 20 inches, and the lncerne from 8 to 10 inches. It was interesting to observe how the clover plants had turned into plants more or less robust and large, in accordance as their roots were supplied with a larger or smaller quantity of those nodules which, in the opinions of the best authorities, have been now proved to supply the plants with nitrogen derived from atmospheric sources. Altogether, we came to the conclusion that the roots of these plants are capable of doing all the work of a subsoiler in breaking up the pan, which is often the most formidable obstacle to be contended with in the cultivation of all our old arable soils. I increased the chicory in the case of this field by one-third, as I wished deeply to pipe, and so aerate the soil, and bring up the manurial matters which must have filtered downwards in past years. Arthur Young, I may observe, objects to chicory for hay on the ground that it is difficult to dry, and no doubt there is something in this objection; but I have found two advantages from its use-one is that, as a certain proportion of it always throws up long strong stems pretty early, these support the whole crop, and so greatly increases it, and favours the grasses generally; the other is, that the stems of the chicory aerate the cocks of hay, and cause it to dry much more quickly. Hay with ehicory in it should be used within a year, as, if kept longer, it creates much dust in the hay. I usually sow $2 \mathrm{lb}$. of chicory, and think this is, as a rule, a sufficient quantity, but that in dry lands $3 \mathrm{lb}$., and perhaps even $4 \mathrm{lb}$., may be used with advantage. $\dagger$

* This pan was composed of very small particles of soil washed down from the soil above. This pan evidently was not formed solely from ploughs and horses, but owed much of its hardness and compactness to the smallness of the washed down particles, which may be so small at to arrest capillary attraction.

+ I have since overeome the objections to chicory as rcgards the bay crop by grazing the land late in the spring. (Vide Bank field experiment, Appendix III.) 
Since writing the preceding remarks I have had another visit from my friend, D1. Voelcker, who inspected (September, 1897) the field, and at the close of the most prolonged drought we have ever had. Part of the field consists of strong clay, and my friend cut out of this, with his pocket knife, several sections of soil, in each of which was a chicory plant, and called my attention to the fact that the soil was soft and friable, having been kept in that condition by the powerful roots of the plant, and also, no doubt, by the moisture it had brought up from a depth in the land out of reach of the effects of the drought. I am now so satisfied with the results from deep-rooting plants that $I$ am, as an experiment, going to add a pound of parsnip seed per acre to one of my next season's mixtures, in order to deeply penetrate the soil, and increase in it the amount of vegetable matter.* It should be considered, further, in this connection that, by virtue of the acids in their roots, plants have the power of making use of the manurial matter contained in stones and gravel in the land, and it has been found that if you bury in the soil a block of polished marble, the roots of plants will literally engrave the surface of the marble. One of my numerous correspondents, who had read a letter of mine in the Scotsman, wrote to me on the subject, and headed his letter, "Out of these Stones Bread," and it is literally true that plants can, in great measure, by virtue of the acids in their roots, supply themselves with some of the materials for the manufacture of bread. Notwithstanding this unusually dry season, I have found that the roots of chicory plants only about five months old have gone down about 18 inches.

I now turn to the two poor land fields, one of which, as $I$ have shown (vide page 28), was of the poorest and most exhausted soil imaginable. The kinds and quanti-

* Parsnip seed was sown in the Outer Kaimrig field in 1890, but from that experiment I have formed the opinion that chicory is superior to parsnip as a deep-rooter. 
ties of seeds used in the mixtures are given on pages 29 and 30 . The poorest field gave a crop, as we have seen in a previous chapter (vide page 30 ), of not less than 2 tons an acre, and the aftermath kept $5 \frac{3}{4}$ lambs per acre for eight weeks, and afterwards 2 ewes per acre for fourteen days. The better field of the two was grazed with sheep and lambs as follows:-Three ewes and their twin lambs per acre from April 25 to July 10, and afterwards about 2 ewes per acre up to October 1.

In the opinion of my head shepherd the grazed field has given most satisfactory results as regards the amount of stock kept, and the effects produced on the stock were excellent, both as to their bealth and the progress made by the lambs. My factor (a practical farmer), who manages the farm, is of opinion that the results obtained could not be surpassed, and advises me to stick to the same mixture for the future. The fields, during my absence from home, were visited by one of the most advanced tenant-farmers in the South of Scotland, and as he has had great experience in laying down land to grass (having laid down to permanent pasture about 400 acres), I think it well to quote part of the letter he afterwards wrote to me:-

"I was very fortunate in going at the right time, as your hay-cutting was in progress, and so I had an excellent opportunity, both of seeing the grasses growing and amongst the hay on the high field at Clifton. The crop I thought a remarkably fine one for a field of light hill land. The first thing that struck me was the extraordinary take of red and alsike clover, compared to the small quantity sown per acre, which leads nue to doubt the system pursued generally of sowing 12 or $14 \mathrm{lb}$.

"The kidney vetch seems to be a remarkable forage plant to grow on light gravelly soil, and for such I think it very valuable. The burnet and chicory also seemed deep-rootiug, fine plants for standing dronght, and, from the state of the pasture, nuch appreciated by sheep, as they were so closely eaten down. For your fine crop of hay, however, I noticed you were in the largest 
measure indebted to the reil and alsike clover. The grasses will, I have no doubt, sliow more later.

"The pasture field adjoining of young grass [the grazed tield alluded to] astonisherl and pleased me even more than the bay. The amount of stock on it and the quantity of grass is wonderful, and your manager told me it was stocked in April. I remarked how closely the sheep har eaten the burnet and chicory, and here, again, how the kidney vetch showed on the gravelly soil."

As I had asked my correspondent to be kind enough to give me any hints or suggestions as to my procedure of laying down, he further remarked, in the letter quoted from, as follows :-

"I have a very strong opinion, and that founded on experience, that your system, followed by a liberal use of cake on the pasture, would show results even nnore surprising than those attained. This I mentioned to your manager, who said it was thought an objection to the sale of the lambs their having been fed on cake. Those who use cake for their lambs, from this time of year, prefer those who have learned to eat it. If I farmed Clifton I would spend $£ 500$ per annum on cake, and I feel certain it would pay. I spent $£ 1700$ on it last year, and so I know something of the results, and I intend, so long as it is as cheap as it is now, to use more than ever. It is the only way land can be kept in condition and rents paid."

In the opinion, then, of the eminent agriculturist I have just quoted the farming of the future resolves itself into plenty of stock and abundance of grass and oilcake to feed it, and with his view I need hardly say that I entirely concur.

And here I must note one point of importance as regards the two poor fields to which his letter refers; that is, that neither were re-seeded in the spring, and yet they were so completely filled with plants that I was under the impression that this operation, the necessity for which I have fully pointed out in a previous chapter, had been carried out. I regard this result as 
of great importance, for it proves conclusively that, when the conditions are as perfect as they ought to be, the quantity of seed used in the case of these fields is quite sufficient; and further, what I had litherto thought to be impossible, that land can be so perfectly laid down that no blanks may occur. Careful tillage, then, and the eareful seeding of the land, would often save the re-seeding of the land, which, as I have shown, will usually cost about one shilling an acre for labour, besides the value of the seed. I may add here that a very trifling, or rather apparently trifling, defect in the state of the land will often make a large difference in the results obtained, and of this I had an instance this year in the case of a field about two-thirds of which was laid down with oats, and the remainder with barley. The latter showed so poorly as compared with the former that one would have supposed that either the seed had been bad or that the crop had affected the result; but I found, on going into the matter, that the oat.sown portion of the field had been ploughed much earlier in the season, and that the soil had therefore had time to solidify, while the soil in the barley portion had been much more recently ploughed; though the whole field was smoath above, the soil in the barley portion was too open below, and as there was a drought many of the seeds had not sprung, or, having sprung, must have perished from want of moisture. I now propose to offer some remarks on the quantity of seed which should be used, a subject as to which there is a considerable difference of opinion.

And here the reader will remember that Arthur Young said, as I have pointed out in the chapter devoted to him and his opinions, that whatever system of laying down land to grass is pursued a liberal amount of seed is essential to success. Mr. James Hunter, the well-known agricultural seedsman of Chester, tells me that of all his customers I am the most liberal seeder, and he has more than once even 
remonstrated with me as regards the quantity of seed I put down. This I was induced to do, partly from my own observation, and partly from the remarks of the late $\mathrm{Mr}$. Brotherston-an excellent botanist, who had paid much attention to the whole subject of grasses and their cultivation-who was much in favour of liberal seeding, and the more I have considered the subject the more certain do I feel that Arthur Young is right as regards the opinion he held as to liberal seeding being essential to success. For what are the main points to be kept in view? Are they not to cover the ground as quickly as possible with as much grass as it will hold;* and an equally important, or even more important, point, to fill the land as soon as possible with a large quantity of roots, to the end that its physical condition may be maintained, and even improved? And when we come to considel the numerous causes of loss that are liable to occur from defective seasons, the ravages of birds and field mice and insects, and defective conditions of soil, is it not evident that if we wish to have a full take of grass we must put down plenty of seed? It is true that by liberal feeding with cake on the land, or by manuring in some other way, a thin supply of plants on the land will gradually tiller out and cover the ground; but while this process is going on what evils and losses are occurring! The numerous parts of the soil which are unfilled with roots run together, or solidify gradually from the action of the elements and the tread of the stock, weeds and bad

* A pasture not fully occupied with plants renders the whole land more liable to suffer from drought, and this is, of course, more especially the case when drying winds sweep over it. In the case of a young pasture the conserving of moisture is obviously a point of the first importance, as plants more often suffer from lack of moisture at a critical period of their growth than from any other cause. The land may be ever so rich, but without a good supply of moisture the pasture cannot take advantage of the plant food present. Every bare spot in a pasture, then, though only an inch in width, has a tendency to starve the plants in its immediate neighbourhood in the event of the season being a dry one. 
grasses find ample spaces in which to establish themselves, and the production of the field is, of course, far below what it would have been had it been at once filled with grass plants; and the intrusion of moss is sure to take place in a greater or less degree, in accordance with the nature of the soil and climate. It should be considered, too, that if the plans of the farmer make it advisable that he should feed stock with cake on a fully-planted young pasture, he will obtain additional advantages from the land being well filled with plants. It is evidently, better, then, from many points of view, to at once fill the ground with the plants you wish to remain in permanent possession, and that it pays better to spend a little more on seed than to make up, or partially make up, for the deficiencies of thin seeding by subsequent manuring, there can be no doubt. But what is a full seeding? or a seeding sufficient to insure the land being well filled with plants? If the selection used should be of the same kinds as those recommended by me, then it is plain that, from the results obtained, $20,000,000$ of germinating seeds would be an ample supply, as the mixture I have used contains 19,931,145 in the case of the field cut for hay, and in which Italian ryegrass was put down to increase the hay crop; and in the case of the other field alluded to, and which was grazed, and the results from which could not be surpassed, 18,872,745 germinating seeds were put down. But seeing that, from the total absence of blanks in the fields (a point to which I have previously alluded), all the conditions must have been extremely favourable, it is probable that it would be safer to assume that $20,000,000$ of germinating seeds per acre should generally be used, though in the case of land in very fine tilth the quantity used by me, or, say, about 19,000,000 of germinating seeds, would be sufficient. In 1903 the Inner Kaimrig and Harewells fields, then being in fine tilth, in consequence of the vegetable matter grown on the land, were sown down with a reduced seeding (vide 
Appendix III.) In the case of the first field the take of grass shows that we have lost nothing by reducing the amount of seed. In the case of the second it is rather early to form a decision, but, as far as we can see at present, no loss will occur from reducing the amount of seed, and certainly none has as yet occurred in the case of the hay crop and foggage obtained from the field this year. Let us now turn to a point of great importance in the quality of the seed to be sown.

To an unskilled agriculturist a grass plant is a grass plant, and there is nothing more to be said about it as long as it comes up and flourishes. But there is, of course, as much, or perhaps even more, difference between grasses grown from different qualities of seed as there is between sheep or cattle of the same breed, and the quantity and quality of the herbage to be produced differ largely in accordance with the goodness or inferiority of the grasses from which the seeds put down have been gathered; and the evils arising from seed, which. though genuine, may be of inferior quality, cannot, as far as my experience goes, be remedied for a great many years-if, indeed, ever. As to these points, we have had ample experience on this property by giving parts of fields to rival seedsmen, and in one instance a whole field to one and a whole to another; and the tenant, to whom I have previously alluded, has confirmed my experience, and one day said to me that if lie hained, or turned the stock out of, a field sown with the seed of a certain seedsman the grass recovered far more quickly than it did in the case of another field sown with seeds supplied by another seedsman. And this supremacy of one plant over another of the same species is by no means so evanescent as one would be inclined to suppose, though eventually, from climatic causes and the conditions of soil, there would be a tendency for the inferior and superior plants to eventually arrive at similar powers of production, though this is a point which requires further investigation; and I am not aware 
of any experiment having been made with the view of determining how long it would take, say, for cocksfoot plants, grown from the finest New Zealand seed, to approximate to plants grown from the, comparatively speaking, $d w a r f$ plants which are natives of our country, or from the seeds of any other inferior cocksfoot plants. On one occasion, in 1884, I gathered cocksfoot seed from plants in this park, and Mr. James Hunter, of Chester, on June 26, 1885, sowed it in line with New Zealand cocksfoot, American, and seed of German growth. $\mathrm{He}$ reported that the last three germinated on July 4, and the former on July 13. The Clifton Park cocksfoot plants were very dwarf, and quite different in habit of growth from the other cocksfoot, and gave a much smaller amount of grass, and yet it is almost certain that the fine New Zealand cocksfoot was the produce of plants very similar to those growing wild in this park. But though plants will, of course, in time improve or decline to the climate and soil they live in, it is probable that many years would elapse before a deeided change would occur one way or another. The only means I have of forming an opinion here is in the case of a field, the Lake field, 20 acres-low-lying flat alluvial landwhich was partly sown with seed supplied by a local seedsman, and partly supplied by one of the most eminent seedsmen in England. The local seedsman knew that the comparison was to be made, and, no doubt, did his best, and there was no reason to complain of the germination or trueness of his seed, but the difference in the result was most marked, and the cattle declined to eat his plants so decidedly that one would imagine they had been fenced off the field. It was interesting to observe how exactly the cattle had stopped grazing at the exact spot where the rival seedsman met, and eventually I had to send a boy to herd the cattlle on to the acres which had been allotted to the local seedsman, and though the field (it was sown in 1884) is now (1898) grazed evenly over without compulsion there is still a 
superiority apparent in favour of the superior seed. In 1903 I enclosed two plots of 18 feet square in each seedsman's portion of the field, and, after letting the grass grow as if for a hay crop, had it cut and taken direct to the weighing machine. The result showed a difference of 20 per cent. in favour of Mr. Hunter's portion. The trial was repeated in 1904, when it was found that there was a difference of 13 per cent. only in favour of $\mathrm{Mr}$. Hunter's portion. The aftermath of Mr Hunter's plot shows this year (1904) a marked superiority to that of his rival. From these facts it seems obvious that, in the case of laying down land to permanent pasture, great care should be taken to provide the very finest seeds.

Another difference also attracted my attention as regards crested dogstail. It is well known that stock reject the wiry flowering stems of this grass, but I was struck with the fact that the stems of seed supplied to me by Mr. James Hunter of Chester had a much softer and more succulent appearance, and on enquiry was told by my shepherd that these were eaten by sheep, though the stems of the wild dogstail plant are rejected. On referring this point to Mr. Hunter, he informs me that the seed which he sells of this plant is collected from meadows on the Rhine in Holland, and adds that it is possible that, from the damp nature of the climate where it is collected, it may be more succulent than the wild native plant.

From the facts previously given, it seems evident that the whole subject of the difference of production in grasses of the same kind, but grown under different conditions of soil and climate, deserves close investigation, as, even from my individual experience, it seems evident that there are far greater differences in the result than might be supposed from sowing seeds of the most superior kinds, and that these results probably are carried on over a much greater length of time than one would be inclined, at first sight, to suppose. I 
now propose to take each forage plant separately, and offer some remarks as to its quality and general merits.

Cocksfoot grass (Dactylis glomerata) calls for little remark, as, to use the words of Mr. Faunce de Laune, "it is by far the most valuable of all grasses, because it grows on all soils, it produces the greatest amount of keep, it is the most nutritious grass; it also seems to grow faster and stronger in extremes of weather, either wet or dry, than any other grass." Taking into consideration its productiveness, it is the cheapest grass that can be grown for land that is to lie in grass for four or more years, for though timotly seed to start with is cheaper than cocksfoot the productiveness of the latter grass in the course of about three years pays for the extra cost of its seed. It is certainly the most valuable for temporary pasture, and Sinclair says that, "for alternate husbandry, it appears to have a greater variety of merits for this purpose than almost any other grass. It soon arrives at maturity, it bears cropping well, is very productive, and its nutritive powers are considerable. It is much less impoverishing to the soil than ryegrass, and when ploughed it affords a greater quantity of vegetable matter to the soil. It has been objected to cocksfoot that it rises in tufts, and is apt to become coarse. But this objection will apply to every grass that is not sown sufficiently thick to occupy with plants every spot of ground, and that is not sufficiently stocked to keep the surface in a succession of young leaves. It is the practice of thin sowing, and the strong appearance of the plant, that occasion it to appear a hassocky grass." And he subsequently expresses the opinion that Dactylis glomerata, from its more numerous merits as compared with other grasses, should constitute three parts of a mixture of grasses adapted for the purpose of alternate husbandry. I have now a ten-year-old permanent pasture as fine as a lawn, and a mass of cocksfoot grass, but then I used $16 \mathrm{lb}$. 
an acre of the finest seed. I have been particularly struck with the value of this grass in alternate husbandry in the case of the hay crop, and have found that it is a far safer grass to grow than any other, from its withstanding drought, and have found that I bave had a most luxuriant crop of hay in a dry season, when my neighbours, who relied mainly on ryegrass and clovers, had very poor crops. But notwithstanding all that has been written in favour of cocksfoot for such a number of years past, I have often heard it objected to by farmer's as a coarse grass. It is quite true that it may become so if thinly planted and badly managed; but just as from the human animal you may produce the finest kind of English gentleman or the bloodthirsty cannibal, who only differs from the brutes by being worse than them, so there may be produced from cocksfoot a beautifully-fine grass or a grass of the coarsest and most objectionable quality. In connection with cocksfoot it may be well to remind the reader that I have previously pointed out that, in making a pasture, regard must be had in particular to the quantity of the produce of a grass, and also to the safety of production from it in dry seasons. The nutritive value of cocksfoot, it should be observed, is, according to Sinclair's analysis, 10 per cent. higher than perennial ryegrass. Sinclail" remarks that the ryegrass ranks with those grasses which contain the least nutriment. It is seldom that, as in the case of cocksfoot, we can combine both qualities, but we must endeavour to do so as closely as possible, and that is why I rank tall fescue as second in merit in the list of large grasses.

Tall fescue grass (Festuca elatior) is, we are told by Sinclair, nutritive and very productive, and one of the earliest grasses with regard to production of foliage early in the spring. It has also great powers of resisting drought, which, I need hardly say, is a quality of great importance, and more especially, of 
course, with reference to light soils in the, comparatively speaking, dry climates of the eastern sides of these islands. Writing on agriculture in 1888, in Morton's New Farmers' Almanac, Mr. Faunce de Laune say's, with reference to this grass, "I imagined in 1884 that I was the first person who had noticed its wonderful quality of witlistanding drought. But the same quality was also observed the same year in America, and it was only in October, 1887, that I found, in a book written by the late curator of Glasnevin Botanical Gardens, the same grass mentioned as growing luxuriantly on a dry calcareous soil."

I am informed by $\mathrm{Mr}$. James Hunter of Chester, the well-known seedsman, that:-

"Great care requires to be exercised in purchasing this grass, as there are two kinds supplied to farmers under the name of tall fescue-the first valuable, and the second worthless-and that is evidently why there is a difference of opinion as regards this grass. The former-i.e., the valuable kind-is grown for its seeds in the Rhenish provinces in a limited district, and is supplied to seedsmen who will pay the price for it; and this price, the moment any increase of competition occurs, naturally runs up to a ligh level, and the difficulty of obtaining a regular and considerable supply of the seed at a reasonable price leads to the importation of the tall reed fescue of New Zealand, which is an extremely coarse and harsh grass, and quite unsuitable as a pasture grass. Any one seeing it in a pasture would be sure to condemn it, and hence the had reputation into which tall fescue has fallen. As the Rhenish seed costs about twice as much as that of the reed fescue from New Zealand, there is therefore a strong temptation to supply the latter instead of the former, and it is thus of obvious inportance to obtain a guarantee as to the kind supplied, and also to send it to the botanist for exanination. It may be well to mention that in a sample sent to we of the New Zealand species there is ergot."

Tall oat grass (Avena elatior).-This is a very hardy, drought-resisting, and productive grass (for which quality it is much valued on the Continent), 
and, the reader may remember, was much esteemed and largely sown by the great Arthur Young, who, however, ultimately gave it up in favour of cocksfoot, which, in his opinion, much exceeds it. At one time the late Mr. Faunce de Lanne considered Avena elatior to be a grass of medium quality, but subsequently saw reason to place a much higher value on this grass, and states that in this view he was supported by Mr. Moore, the late curator of Glasnevin. Sinclair says that it "attains to maturity from seed in a very short space of time, and that it is very early and productive in the spring, and during the whole season grows rapidly after cropping, and the culms are succulent." But the produce, he tells us, "is very deficient of nutritive matter, which contains an excess of the bitter extractive and saline principles." There can be no doubt of its value for permanent pasture, but it is, in error, objected to by some for land that is ever to be lifted again, because of the supposed difficulty of eradicating it; but Sinclair recommends it for alternate husbandry, though in small proportion-the mixture he advises being 75 per cent. of cocksfoot, while the remaining 25 per cent. is to consist of hard fescue, meadow fescue, rough-stalked meadow grass, tall oat grass, timothy, ryegrass, and white clover. Sinclair says nothing of the difficulty of eradicating this grass when ploughing up, and I cannot help thinking that the variety of tall oat grass which has ereeping underground roots is the kind to which objections have been raised on account of the difficulty of eradicating the roots. I may also remark that Arthur Young, who, as I have pointed out, at one time sowed it largely, says nothing about the difficulty of destroying the roots on again ploughing up the land.

I have now considered thi'ee grasses of great importance-cocksfoot, tall fescue, and tall oat giass-and they all three possess most desirable qualities, being early, drought-resisting, hardy, and productive. On 
reference to the table of relative productiveness (vide Appendix I., the reader will see that they stand at 100 , while two of the other tall grasses-timothy and Italian ryegrass-stand only at 75 , while meadow fescue and meadow foxtail-the two remaining tall grasses-only attain a proportion of 70 . The first three grasses are thus 25 per cent. more productive than the secondly mentioned grasses, and 30 per cent. more than the last two alluded to. This question, then, naturally arises-Why should we not use the first three grasses exclusively for the large grasses of the pasture? Add to them, say, rough-stalked meadow grass, golden oat grass, crested dogstail, and hard fescue to fill up the bottom of the pasture, and also chicory, burnet, yarrow, and kidney vetch, sheep's parsley, and lucerne-the whole pasture would thus mainly consist of hardy and drought-resisting plants, with the addition of alsike, late-flowering red clover, and white clover, and the mixture would consist of fifteen kinds of plants, and supply, too, that variety and kind of food which would be welcome to stock. In these days, when farming profits are small at the best, and it is always a matter of doubt as to whether there may be any profits worthy of the name, it is obviously of the greatest importance to put down a seed mixture which will at once give the greatest amount of production, and, from the hardy and drought-resisting character of the plants, the greatest safety of production when seasons are dry or unfavourable. The season of $\mathbf{1 8 9 6}$ was particularly dry, but, in spite of the great drought, a mixture closely approximating to that suggested above gave wonderful results, and the pasture remained of a beautiful green colour. I may add that even in the moister climates of Great Britain a preference should certainly be given to drought-resisting plants when laying down to either temporary or permanent pasture. It is true that in the moistest climates a dry season may not wither up plants which are not remarkable 
for drought-resisting powers, but seeing that very dry seasons would certainly diminish the production from grasses of inferior drought-resisting power, while such seasons would affect but little grasses and plants best able to resist drought, it seems evident that a most decided preference should be given to drought-resisting plants, whether the climate is a dry or a moist one. There is, however, an exception to be made in the case of rough-stalked meadow grass, because, though it does suffer from drought, it recovers rapidly after rain, and also spreads so rapidly that it is valuable for filling up the bottom of a pasture, as I have elsewhere shown, even in dry and exposed situations.

I now proceed to make some remarks on the other grasses commonly used for permanent and temporary pastures, and also on the other plants usually associated with them.

Phleum pratense (timothy), as the reader will remember, is, by the table I have supplied, 25 per cent. less productive than the first three grasses I have treated of-cocksfoot, tall fescue, and tall oat grasswhich may readily be understood when we read in Sinclair that "this grass is very deficient in the produce of aftermath, and is slow in grow th after being cropped," two very serious defects, which certainly do not seem to be compensated for by the fact that its early spring produce is said by Sinclair to be more nutritive in the proportion of 9 to 8 , though the quantity of spring produce was the same in the case of both plants. 'Timothy is unsuited for dry soils, and does not appear to have the merit of being a droughtresisting plant. It is recommended by Sinclair partly because, as it does not put out its flowering stems till June, it can be fed to a late period of the year without injury to the hay crop. But in this respeet it is equalled by cocksfoot, and as that grass is distinctly more productive, and certainly suitable to nearly all soils and situations, and also more drought- 
resisting, I confess I am unable to see why it should be allowed to occupy space which might better be filled with cocksfoot or tall fescue. The seed, it is true, is much cheaper than that of cocksfoot or tall fescue, but if these plants are so much more productive the saving in cost of seed would soon be out-weighed; and in the case of lands which are to lie from four to six years a little extra cost of seed seems hardly worth considering. In his remarks on the suitability of the varions grasses for alternate husbandry, Sinclair says of timothy that "it is very productive in the fore part of the season, and the foliage and culms are very nutritive; but it runs much to stalks, and the aftermath is very trifling."

Lolium Italicum (Italian ryegrass), like timothy, is 25 per cent. less productive than the three grasses first treated of. Its value is well known, and, as regards its nutritive value, earliness, productiveness, and quickness of growth after it has been mown, it far surpasses the perennial ryegrass. But it should be used with great caution for permanent pasture, as it is a biennial, and, as in the case of perennial ryegrass, its excessive use would leave spaces liable, or rather certain, to be filled by weeds and worthless grasses. When, however, either in the case of permanent pasture or for temporary pasture to lie for four or more years, it is intended to take a hay crop the first year, then 2 lbs. or 3 lbs. of Italian may be used, and is generally recommended, in order to in. crease the hay crop. I have used it for this purpose, but confess to having some little doubts about its value as regards increasing the hay crop, as on one occasion, when I added Italian ryegrass to the lower portion of a field, with the view of increasing the hay crop, it mast certainly diminished it, and the difference in favour of the part of the field which had no Italian ryegrass was most marked. I regret now that I did not try and estimate the undoubted loss caused by 
the use of this grass. No doubt, being a rapid grower and greedy feeder, it had deprived the grasses sown with it of nutriment at a critical period of their growth. From what I saw on the occasion alluded to, I think it very advisable that further experiments should be made as regards the effect of Italian ryegrass on the hay crop when it is associated with other grasses.

Further observation has led me to the conclusion that to increase the hay crop, and also aid in holding up the elover and the crop generally, tall oat grass would be preferable to Italian ryegrass, as it is free from the defects of the latter (vide Appendix III.) But tall oat grass is too expensive to be used on a large enough scale for increasing the bulk of the hay crop and holding up the crop, and I now think that, say, $2 \mathrm{lbs}$. or $3 \mathrm{lbs}$. of Italian ryegrass should be added.

Lolium perenne (perennial ryegrass), as the reader will see by reference to the table, is 30 per cent. less productive than the first three grasses on my list, and 1 have written so much on it previously that no further remarks on this grass are here required. I may add that, after a long experience, I am sure that, for the reasons previously given in this book, it does not pay to use it at all for perinanent pasture, nor for temporary pastures which are to lie for four or more years. I am even doubtful whether it should be used for temporary pastures which are to lie for two or three years, but, if used, it should be sown in small proportion-5 lb. or $6 \mathrm{lb}$. to the acre.

Festuca pratensis (meadow fescue).-'The merits of this grass are too well known to call for any remark here. Sinclair says that "it is much slower in growth after being cropped than cocksfoot," and this, of course, is the reason why in the table it stands as being 30 per cent. less productive.

Alopecurus pratensis (meadow foxtail). - This grass, too, calls for little remark, as its merits are so well known, but "the weight of grass produced in one 
season is," we are informed by Sinclair, "considerably less than the amount to be obtained from cocksfoot," and that, of course, is why it stands, for productive purposes, 30 per cent. below that grass. According to Sinclair, "this grass, under the best management, does not attain to its fullest productive powers from seed till four years;" but later experience shows that the successful cultivation of this grass largely depends on the suitability of the soil and the sufficiency of moisture supplied. Thus at Carbeth, Killearn, Stirlingshire, meadow foxtail, sown in 1884 on a good stiffish loam, yielded in 1885 (the year following the sowing of the seed) such satisfactory results that it is stated of this grass by Dr. Wilson, in his able report, that "of all the grasses examined meadow foxtail seems to combine best productiveness and nutritive qualities." Though very valuable for permanent pasture, it is, however, not desirable for alternate husbandry.

I have now alluded to all the tall grasses commonly used for permanent pasture-i.e., cocksfoot, tall fescue, tall oat grass, timothy, meadow fescue, and meadow foxtail-but there is a sixth of which I lave had some experience, and which, for hay in especial, seems to me to be the most desirable of all the tall grasses, Poa fertilis, or serotina, and Sinclair tells us that "it adds much to the value of a sward from its nutritive qualities and powers of early and late growth:"

Poa fertilis, or serotina (fertile or late-flowering meadow grass), has for a great many years been highly esteemed in the United States, and as it perfects an abundance of seed, and can therefore be easily propagated, it seems singular that it should have been neglected here. This grass is described in Dr. George Vasey's work, "The Agricultural Grasses of the United States," as Poa serotina, or fowl meadow grass, and he tells us that the culms are from 2 to 3 feet high (about the highest I have grown them here), and that there are some mountain forms, or varieties, 
which have culms only 1 foot or less in length. Mr. J. T. Gould, of New York, is quoted by Dr. Vasey as having found it to grow in almost every kind of soil, but as attaining its greatest perfection in a rich moist one. Professor Phares, of Mississippi (quoted by Dr. Vasey), writes that "in portions of the Western States this grass has, for some years, been very highly recommended," and that "in the Eastern States it has been cultivated for 150 years or longer, and highly valued." Jared Elliott, writing in 1749, spoke of it as growing tall and thick, making a more soft and pliable hay than timothy, and better adapted for pressing and shipping for use of horses on shipboard. He says that it never becomes so coarse and hard, but the stalk is sweet and tender and eaten without waste, and another writer quoted by Dr. Vasey, Mr. Charles L. Flint, testifies to the same effect. The tenderness of the stems is most remarkable. On one occasion I had sheaves of this grass cut in a thoroughly ripened state, as the grass was grown for the sake of the seed, and yet my cows ate up with relish every part of the grass after the seed had been threshed out. The stems, however dry, are so tender that they break asunder with a slight twitch of the fingers. The grass, when allowed to grow tall, and by itself, is so tender that it is liable to be laid by wind and rain, but if it were mingled with a sufficient proportion of timothy to keep it erect $I$ see no reason why it should not be then grown for hay.

Poa trivialis (rough-stalked meadow grass) is well known to be a very valuable grass in certain situations, and, after writing at length on it, Sinclair concludes "that the Poa trivialis, though highly valuable as a permanent pasture grass on rich and sheltered soils, is but little adapted for the alternate husbandry, and unprofitable for any purpose on dry exposed situations." Elsewhere he says that on such situations "it yearly diminishes, and ultimately dies off, not unfrequently in 
the space of four or five years." As regards productiveness, a reference to the table will show that it stands at 60 , or 40 per cent. less than the first three grasses given. But notwithstanding what Sinclair has said-and I need hardly say that I differ with him with great diffidence-my most recent observation of it, in the case of a dry and rather exposed situation, is that it is a valuable grass, for, though easily affected by drought, it revives again with great rapidity when rain has fallen, and, from its spreading habit, is valuable for filling up the bottom of a pasture in any situation. In the case of a pasture in its fourth year, and which contains the dry and rather exposed situation alluded to in the last sentence, it sbows no sign of decline, and I have therefore no hesitation in recommending it for pastures in any situation that are to lie from four to six years in climates resembling the driest parts of Roxburghshire.

Avena flavescens (golden oat grass) is valuable for filling up the bottom of a pasture, and also for its hardy qualities and suitability to almost any kind of soil. Being one of the smaller grasses, its productive powers are not large, but as the flowering-stems are long (about $2 \frac{1}{2}$ feet), it would therefore yield fairly well in the hay crop. It stands in the table at 55 .

Poa pratensis (smooth-stalked meadow grass) also stands in the table at 55 , but is so decidedly condemned by Sinclair and other writers that I have now determined on not sowing it again, though, as the reader will remember, I used $2 \mathrm{lb}$. of it in the mixture which, in 1895, gave such satisfactory results; but it is quite evident to me that Poa fertilis, or serotina, is much to be preferred to it, and I consider $1 \mathrm{lb}$. of this Poa very desirable for well-sheltered and low-lying situations.

Festuca duriuscula (hard fescue) is a grass which has been favourably spoken of by most writers on grass. Sinclair considers it to be "one of the best of the fine, or dwarf-growing, grasses." "It springs rather early, 
and the produce is remarkably fine and succulent." $\mathrm{He}$ elsewhere observes that it withstands the effects of severe dry weather better than many other grasses. Its productive powers are inferior, and are stated in the table at 50. It is, however, useful for filling up the bottom of a pasture, and it is a drought-resisting grass.

Anthoxanthum odoratum (sweet vernal grass) stands at 50 in the table. Sinclair considers that its early growth and hardy and permanent nature uphold its claim to a place in the composition of all permanent pastures: but, as its seed is scarce and dear, its use cannot be recommended while there are other grasses which have equally good qualities, and are much cheaper.

Cynosurus cristatus (crested dogstail).-The productive power of this grass is small, and the reader will perceive that it stands at 45 in the table; but Arthur Young speaks highly of it, and so does Sinclair, and he goes so far as to say that " a sward of the best quality, particularly under circumstances where sheep are a principal object, cannot be formed without an admixture or proportion of the crested dogstail grass." It has the merit of being very drought-resisting, and it thrives well on dry lands. Many farmers dislike it on account of its wiry culms, but there can be no doubt that it is a valuable grass for filling up the bottom of a pasture.

Poa nemoralis (wood meadow grass), as regards productiveness, stands on the same level as crested dogstail-i.e., 45-in the table, and Sinclair says that "the early growth of this grass in spring, and its remarkably fine, succulent, and nutritive herbage, recommend it strongly for admission into the company of the superior pasture grasses." But I cannot find that it is ever spoken of as a good drought-resisting grass; and, though it may be very suitable for lawns or pleasure grounds, the practical farmer would, I think, rather see any space that might be given to it filled with a safer grass. Festuca ovina tenuifolia (fine-leaved fescue) stands 
last on the table, with a productive power as low as 40 . It grows and thrives on mountain pasture, and is valuable in lawn mixtures, but is never included in mixtures for laying down any kind of pasture.

Poa nervata (nerved meadow grass).- This grass cannot be obtained from seedsmen in this country, and I had some difficulty in procuring seeds from North America. From these I grew a certain number of plants, some of which are growing here now. I have not paid nuch attention to this grass; but Sinclair evidently did, as he says that it is a remarkably hardy grass, and that "it possesses very valuable properties, and will be found a valuable ingredient in permanent pastures, where the soil is not too dry, but of a medium quality as to moisture and dryness." With reference to its hardiness, the writer said that "in February 17, 1814, after the severe winter preceding, this species of $P_{o a}$ was perfectly green and succulent, while not one species of grass, out of nearly 300 different species that grew around it, remained in a healthy state, but were all inferior, and more or less injured by the severity of the weather." I have elsewhere dwelt upon the obvious advantages of confining our attention as much as possible to the cultivation of the most hardy grasses, which, of course, are much safer for the farmer than the less robust kinds, and I hope that the mention I have nrade of the matter may induce seedsmen, and others interested in this important subject, to devote some attention to Poa nervala.

Clovers require no detailed notice here. In Appendix II. some remarks on them, contributed by Mr. James Hunter, will be found.

I now proceed to remark, lastly, on various plants which may be usefully added to grass and clover mixtures.

Chicory and burnet, having been fully treated in what I have written previously (vide Chapter VI.) require no notice here. 
Yarrow (Achillea millefolium).-The value of this plant for permanent pastures has been well known for a long period, and therefore requires no detailed notice. Arthur Young, from what he has written, evidently had a high opinion of it. It will be observed that Mr. James Hunter, of Chester, thinks $\frac{1}{4} \mathrm{lb}$. of it sufficient, and perhaps this may be so in the case of permanent pasture, as the plants spread gradually; but in the case of pastures to lie for three or more years, and which are afterwards to be broken up, I think that $\mathrm{l} \mathrm{lb}$. should be used, as it is desirable to have a good supply of this plant quickly established in the land-partly as food for stock, and partly to insure a large root-growth in the land, so as to furnish much vegetable matter when the land is again brought into arable cultivation. For such temporary pastures I have used $1 \mathrm{lb}$., and do not find it too much. I have been particularly struck with the value of yarrow in seasons of extreme drought, and, in the case of the East Countridge field, I remember observing to my steward that were the yarrow removed the field would have had a totally different appearance, as it was the yarrow alone that maintained the green appearance of the field.

In permanent pastures where the land happens to be very favourable to the growth and spread of yarrow, care should be taken to eat it close down early in the spring, or it will occupy the land to an injurious extent, and so, as I have found, injure a pasture. I was particularly struck with this in the case of a pasture let by me to a cow-feeder. The tenant had no sheep to eat the yarrow down, and the yarrow was also allowed to seed, and the result was that the pasture has been distinctly injured-in fact, the yarrow, in some places, spread so thickly over the ground as to strangle both the grasses and clovers. Had the yarrow been keṕt down by slieep, it seems impossible, judging by my other pastures, that such a result could have occurred.

Kidney Vetch (Anthyllis vulneraria). - This is a very 
valuable plant, and of supreme importance in a severe drought. In 1899 there was a very severe drought, and yet we cut 2 tons an acre from the Big Countridge field, which, from a distance of many miles, looked like a veritable oasis in a desert of scorched hills. For the crop we were mainly indebted to the kidney vetch, which, after cutting, was almost entirely killed, but it had saved the situation, and its immense rootage, covered with nitrogen-collecting nodules, will no doubt tell favourably on the grass and subsequent crops. It is generally supposed that the kidney vetch never stands cutting, but Hayhope Shank field was hayed in 1897, and a small portion of the field, which was again hayed in 1900, showed a fair proportion of the plant. The Big Haugh field was sown in 1893; 2 lb. chicory, $3 \mathrm{lb}$. burnet, and $2 \mathrm{lb}$. kidney vetch were included in the mixture. The field was hayed the first year, and was ploughed for turnips end of 1900. A strip was left unploughed along the fence side on the margin of the Bowmont, and in 1901 (eight years after sowing) this showed plenty of chicory, burnet, and kidney vetch. This seems to show the durability of the vetch, and that it is not injured if cut for hay; at any rate, if cut only once.

Birdsfoot trefoil (Lotus corniculatus) calls for some remark, as it appears in seedsmen's lists and mixtures, though, from Sinclair's account of the plant, neither it nor Lotus major seem to be deserving of attention. Sinclair says that they are greatly inferior to the clovers. The white clover is superior to the common birdsfoot trefoil in the quantity of nutritive matter it affords, in the proportion of 5 to 4 . It is much less productive of herbage." Altogether, there seems to be no good reason for cultivating this plant.

Parsley (l'etroselinum sativum).-I generally put down $1 \mathrm{lb}$. with my seed mixtures, as it is supposed to be favourable to the health of sheep and to be a preventive to liver rot, but $I$ have no evidence to give in support of this view. 
Lucerne (Medicago sativa).-On light, dry, or chalky soils, in the south of England, the Lucerne is of great value, but it seems to be unsuitable to our soil and climate, and I now do not use it. It has been recommended by Sir John Lawes to be used when laying down land to grass, and $2 \mathrm{lb}$. an acre may be added to the seed mixture for permanent pasture.

Eriphorum. vaginatum (cotton grass, or draw moss). - This, though called a grass, is a sedge which thrives best in peaty lands. Its effects on sheep are so rcmarkable that a little space may be profitably devoted to it for the benefit of pastoral farmer's, and with the view of suggesting means for increasing it. A neighbouring proprietor, who is also a practical farmer, has sent me a bundle of letters from correspondents of practical experience in the moorland farms, and also an account of the proceedings of the Teviotdale Farmers' Club, where the subject of this grass was discussed and its merits generally admitted. One of the correspondents alluded to says that the value of a hill grazing is greatly enhanced for blackfaced sheep if there is a good supply of draw moss on it, and that it has a special value in the spring months, though the sheep eat it all the year round. In a very open spring he has seen the blackfaced sheep mellow in the skin and flush in the condition on account of their having had a good supply of draw moss. Another correspondent writes that it is invaluable for lean sheep in a backward spring, and rapidly blings them forward. It is a common saying that a good draw moss year is a good sheep year. A third correspondent points out that, especially in bad seasons, its presence or absence on a hirsel (sheep farm) makes all the difference between being well or badly lambed. None of the various correspondents have ever" heard of an attempt being made to increase the supply of this highly valuable sedge. One of them mentions that when some of the land on which it grew was burnt, the effect of this was to increase the supply ot the 
plants, and a further experiment might be made as to the effect of burning in increasing the supply of this valuable sedge. So far as I can learn, wet ground is essential to the growth of this plant, and one of the correspondents alluded to alleges that it disappears on land which has been drained. Some plants were hrought down from an elevation of 1800 feet on this property, placed in the garden and watered at Clifton-on-Bowmont, but they all died. The head gardener at Clifton Park writes as follows with reference to some plants sent liere from the Lammermoors:-

"Plants of this grass were received here in July, 1901. At that time they were bearing seeds, and these were collected and sown in a soil consisting of peat and silver sand. The seeds germinated freely, and the young plants were kept in the seed box till April, 1902, when they were transferred to their permanent quarters. Some of the seedlings were planted in soil similar to that in which they were raised-i.e., peat and silver salud ; the others were planted in ordinary garden soil. All the plants were kept in these quarters till April, 1904. During the time they were under observation no difference could be detected between the plants growing in peat and those in ordinary soil. Both plots were well supplied with water. Had it been otherwise those plants in the ordinary soil would possibly have suffered more from drought than the others in the peat, as peat retains moisture longer than ordinary garden soil."

These plants have now been transferred to the observation squares in permanent pastures. It seems probable that this valuable sedge could be readily extended by hurdling off pieces of land where the sedge is thickly distributed, and until the seed had been blown away by the wind. It is probable, from the behaviour of the plants here, that they would flourish in any marsliy ground, even though it were not of a peaty character.

I have now noticed all those plants which I think of value for laying down land to temporary or permanent 
pastures, or improving hill pastures, and trust that the remarks I have made on them may be of some use to the farmer.

In the Appendices will be found some interesting and valuable information contributed by $\mathrm{Mr}$. James Hunter, the well-known agricultural seedsman, to whom, in the Preface, I have fully acknowledged my obligations. 


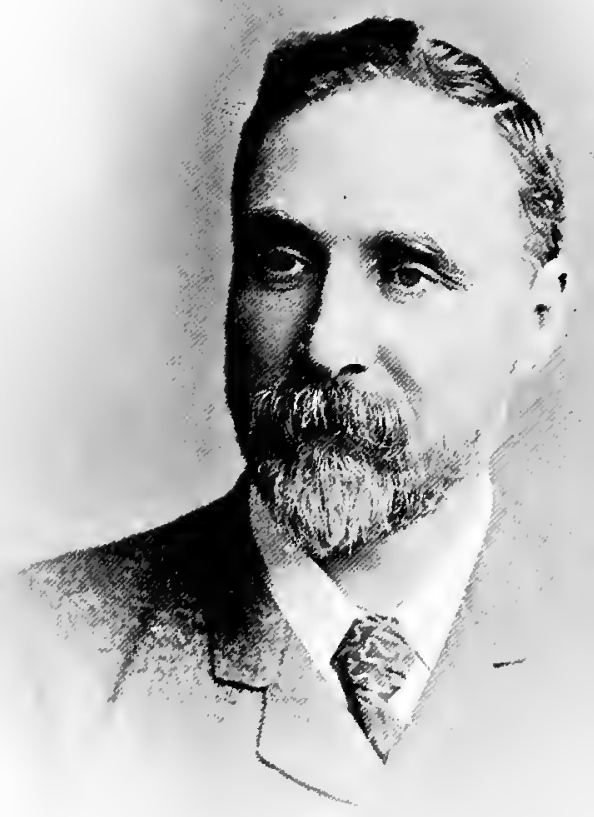

JAMES HUNTER, Chester. 



\section{CHAPTER VII.}

WHY GOVERNMENT EXPERIMENTAL FARMS ARE SO SPECIALLY NEEDED, AND THE LINES ON WHICH THEY SHOULD BE LAID.

T $\mathbf{T}$ is well known that, with but few exceptions, agri1 culturists will not read, and are, indeed, averse to any form of intellectual exertion. This is not peculiar to farmers. I have found it the same in the case of my brother planters in India. The chief explanation of this is that, as a rule, the brightest members of families who have to earn their bread are sent to the professions and the public services, and the remainder to pursuits where no examinations have to be passed, and which do not call for intellectual activity. The natural result, then, is that a lad goes into, or is bred on, a farm, learns the routine that goes on there, and nothing outside of it, for anything outside of it would require that intellectual activity for the want of which he was sent to farming. For a time this answers fairly well, for every farmer gradually acquires a considerable amount of valuable practical knowledge which is suitable to existing conditions. But let any change in the times occur which demands a new system, or important modifications in the old one, and the farmer who knows nothing outside of the routine he has been drilled into is liable to be, and often is, in a very helpless condition in consequence of the want of general agricultural knowledge. Worse still, he is steeped into a thorough belief that the system he has learned is infallible, and therefore suited to any times-a belief which, of course, seals his mind against the intrusion of any new ideas. When 
discussing with a farmer the changes required by the times, and a need for a thorough knowledge of grasses, he pointed to an old pasture, aud said, "I know as much as most of them, and yet I could not tell you the names of one of these grasses." "We are awfully ignorant," said another to me when I was alluding to that or some other farming subject. And the class to which I belong, the landlord class, are in much the same position as their tenants; rather worse, indeed, for the agriculiural ignorauce of the landlords consists of what theologiaus denounce as the worst form of ignorance-a desire not to know-as I have previously shown in the early pages of this book. When, lastly, we turn to the factor or land agent, we shall find that he is simply an estimable gentleman who goes round with a bag, and when he has filled it he lias not the slightest idea whether lie bas done so with the legitimate interest of the soil, the capital of the tenant, or the capital of the landlord, or a mixture of all three. Nor does he appear to think it his duty to make any inquiries on the subject. For many years past he has filled it very largely with the capital of the landlord; and, indeed, this must have been so, or we should not have heard such numerous complaints of exhansted soil. This is simply another term for depleted landlords' capital, which, I need hardly explain, consists mainly of soil. Now, to make any progress in our agriculture in such a way as to enable it to grapple successfully with these difficult times, we must, first of all, take into account the mental condition of the three great classes engaged in laud, and its management and cultivation, and adapt our educational methods in such a way that the classes in question may not be called upon for any form of intellectual exertion. In other words, you must teach not so much by books and lectures as by practical illustration in the field, and such illustration must not consist of experimental plots, but of farms of moderate size, conducted on the lines that any farmer could imitate, though, of course, attached to 
such farms experinental plots might be formed, and used for educational purposes. It is the recognition of the absolute necessity for this practical teaching for classes connected with land that has induced the United States to start its extensive system of experimental farms, and until we do so we can never expect to make rapid progress with the agricultural changes called for by the times. It must be considered, too, that as time advances calls may arise for further and further modifications as communications develop throughout the world, and its prodnce is therefore brought more and more cheaply to our doors.

That such farms would be appreciated by farmers I have had the fullest practical evidence from the number of agriculturists who have visited Clifton-onBowmont, many of whom have visited the farm again and again; and the immense correspondence we have had, and which, of course, has arisen ont of the work on the farm. We have had a fair proportion of Professors of Agriculture as visitors, but few landlords and land agents:* I suppose because the two last classes are not sufficiently aware of the influence they might bring to bear in pushing forward the agricultural changes called for by the times, or perhaps that any changes at all are requisite. But the present "what we know we know, and what we don't know we don't want to know" attitude of these classes would be gradually changed were experimental farms placed within easy reach of a railway. One for the East and another for the West of Scotland would suffice to begin with, and the number required for England and Wales would not be large. I say nothing of Ireland, as that part of the Empire is safely in the hands of Sir Horace

* The visiting list shows an improvement as regards landlords this year. It is as follows :-Farmers, 60 ; landlords, 21 ; land agents, 6 ; agricultural professors, 8 ; seedsmen, 8 ; schoolmasters, 5 ; ministers of the gospel, 2 ; agricultural chemist, 1 ; farm manager, 1 ; baker, 1 ; butcher, 1; shepherd, 1 ; ploughmen, 7 (the last are members of an agricultural educational class in the neighbourhood). 
Plunkett. In this connection I may take the opportunity of thanking the Board of Agriculture for its action, though some might call it want of action, with reference to Clifton-on-Bowmont, in declining to take the part that I suggested with reference to the farm. This was that the Board should print a leaflet on the work of the farm, and send one to each County Council in order to make it known that the farm was open to visitors. The Department declined with thanks, on the ground that to do so would be to identify itself witl a system-the system being as old as agriculture, though the method of carrying it out is on fresh lines. Judging by the number of visitors who have arrived without any aid from the Department, and who have, of course, taken up much of the time of my steward in showing them round the farm, it is evident that had the Department adopted my suggestion we should have been simply overpowered with visitors and correspondence, and I therefore take this opportunity, from a personal point of view, of thanking the Department, though it is not quite so clear that I have any grounds for doing so on behalf of the farming world. I may here add that I offered the Department, well knowing of what use my book would be in the Colonies, twelve copies, to be sent to the various Colonies, but they positively declined to move in the matter, which I partly mention because the reader may be interested to learn that $\mathrm{Mr}$. Chamberlain, though in the midst of all bis Cape troubles, at once responded most cordially to a letter I very reluctantly wrote to him on the subject of sending the books to the Colonies, and undertook to forward them at once to the Australian Govemors. I have also to thank the Board for refusing to support my proposal that the farm should be leased by the Government for a term of years, and carried on till the new system of farming bad sufficiently made its way, as I now clearly see that where you have Departments with hardly any business men in them, the handing over of the farm to 
the Government would probably have done more harm than good, unless, of course, the services of Sir Horace Plunkett could have been obtained, or Mr Chamberlain put in charge of the Department until it should be started on a sound basis.

The experience $I$ have gained since the second edition of this book was published clearly shows me that whatever good the Board of Agriculture may be doing in some directions is far outweighed by the pernicious effect it has in misleading the farmer, and involving him further and further with the manure merchant. The teaching it is directly or indirectly responsible for is not as it, of 'course, should be, in the direction of that agriculture which stands firmly on its own feet, and shows the farmer how to depend on his own efforts for all, or nearly all, he requires. On the contrary, the farmer is taught that if he wishes to grow heavier crops he must go to the manure merchant, and that if he wants to produce more meat he must go to the manure merchant again. The Board may urge that it is not responsible for this teaching, and that it hands over the public funds to Colleges and other educational institutions; but is it not obvious that, on the qui facit per alium facit per se principle the Board is to blame for money being spent in a way that is really adverse to the agricultural interests of the country. This subject is of such importance to the national interests, and especially in connection with the maintenance of the numbers of our rural population, that I enter here into some details to show that the present policy of the Board of Agriculture, and the methods of agricultural teaching practically approved of by it, are calculated to deplete still further our largely exhausted soils, and therefore still further reduce the numbers of our rural population. ,

In my paper read at Cambridge, I said (vide Appendix VII.) that the chemist must become more of a farmer, and the farmer more of a chemist, before either can work effec- 
tively in arresting the downward course of our British soils. And is it not obvious that if, wheu the blind lead the blind, the result is liable to be unsatisfactory, the leading of the semi-blind by the semi-blind is certain to end in much more serious disaster? In the former case both are proverbially liable to be abruptly aroused to the inadvisability of their proceedings, and that, too, before they have gone very far; but when a chemist who is agriculturally semi-blind leads a farmer who is chemically semi-blind, still more unsatisfactory results are, as we shall see, certain to ensue, for they are sure to be the means of doing much harm by the propagation of that most dangerous form of knowledge known by the name of half-truths. In order to prove this it is only necessary to look into the seventh annual Report on Experiments with crops and stock at the Northumberland County Demonstration Farm, Cockle Park, Morpeth. It is there evidently assumed that the British farmer has done all he can for himself by fully employing the natural resources within his reach, and that all that remains is for the chemist to step in and assist the farmer either to increase his crops or improve the condition of his animals by the aid of commercial fertilizers. But the chemist (though adding the name agricultural would lead people to suppose that he is an agriculturist as well as a chemist) really knows nothing of agriculture, and indeed it is obvious that he does not, for otherwise he would first of all inquire whether the farmer does make a full use of all the natural resources at his disposal before advising that various linds of chemical manures should be used. But the chemist makes no such inquiries. He takes British soil in hand as he finds it exhausted more or less by long courses of limings and artificial manures, and tells the farmer that all he has to do is to replace what he has taken out of the soil, and that if he wants more produce from it he must at once apply an increased supply of the chemical ingredients that have been carried off the land. By this process the chemist 
manures the plant and not the soil, while the farmer puts down as little as he thinks will serve to grow the plant, which he could not otherwise effectually do, and the plant, grown through this aid, searches through the soil to absorb the remains of its natural fertility. Thus the decline of our soils proceeds till the humus of the soil becomes so thoroughly exhausted that the diseases of plants increase, and they are more and more at the mercy of the vicissitudes of unfavourable seasons. Then as the fertility of the soil declines, and natural sources of plant food diminish, and are not replaced, or only in most inadequate degrees, by natural agencies, the artificial manure bill must be increased, and it has been so increased that farmers now complain that it amounts to another rent. But such manures, even if they could be had for nothing, would not enable the plants of the farmer to contend successfully with climatic shortcomings which so frequently occur in these islands-excessive drought, or excessive wet, or excessive cold. If the season is perfect the artificial manure will act fairly well. If it is too dry there may be too little water present to convey the plant food into the plant, and if very wet much of the manure may be washed away, and other parts of it, if not used at once, are liable to enter into insoluble compounds in the soil; while if the season is cold the artificial manure cannot raise the temperature of the soil as humus does. It is evident then that what the farmer requires is at once a chemical and a physical agent provided at the lowest cost, which will act with the greatest certainty, no matter what the season may be, and which will continuously increase the humus of the soil, and add to its depth. This he will provide, as I have abundantly shown, by growing a turf of deeply-rooted, and powerfully-rooted, plants. The chemist with his artificial manures can only provide, of course, a costly chemical agent which must always be, as I have shown, at the mercy of the season, and not only cannot permanently 
ameliorate the fertility of the soil, even in the most favourable seasons, but, unless supported by dung or the turf, must deplete the soil. To the agriculturist who has what Locke terms "Large, sound, roundabout sense," the preceding statements are, of course, mere truisms; but as there are many of my readers who, to use Locke's words again, " have not a full view of all that relates to the question, and may be of moment to decide it," it is advisable to refer them to the statements I have made as regards the crops grown without manure, and also to allude to some facts with reference to the experiments made at Cockle Park County Demonstration Farm. These, as we have seen, are made on the assumption that the British farmer has done, and continues to do, all he can for himself, and that it only remains for the chemist to show him how, by the application of artificial manures, he may derive increased crops from exhausted soil. If the assumption is correct then the results of the experiments are valuable to the farmer, but the assumption, as I have abuudantly shown at Clifton-on-Bowmont, is not correct, and the experiments are really only of value to show the farmer how, with the present low price for agricultural produce, he may lose his money if, after having adopted my system and manured his land with turf, he choses to add artificial manures. The experiments made at Cockle Park, in order to stimulate the seed hay crop with various manures from a cost of $13 \mathrm{~s}$ to $36 \mathrm{~s}$ per acre, show results which, as compared with my results from turfmanured land, are distinctly inferior, so that the farmer working on my system would have lost the value of the artificial manures had he used them. When I pass to the potato experiments at the College, as shown in its seventh annual Report, the results are still more striking. As shown in my paper delivered at Cambridge, Aug., 1904, I last year produced, without any manure other than turf, 13 tons $14 \mathrm{cwt}$. of potatoes per acre. With the aid of 12 tons dung and $6 \frac{1}{2} \mathrm{cwt}$. artificials, costing 
101s $1 \mathrm{~d}$, the College produced 13 tons $7 \frac{1}{2} \mathrm{cwt}$., and the College estimates that this manurial application brought in a profit due to manure of $£ 2311$ s $2 \mathrm{~d}$. But how was this profit estimated? By comparing the yield with that of the no-manure section, which only produced 2 tons $16 \mathrm{cwt}$. But if this section had been coated with a deeply-rooted turf there is no reason to suppose, as mine is a poor land farm, that it would not have produced as much as the manured section, costing $101 \mathrm{~s} 1 \mathrm{~d}$ per acre, and it must be remembered that, when growing the turf, no expense other than that of the seed would have been incurred, while the hay and grazing obtained when growing the turf would, at a small cost, have yielded a handsome profit*-the average cost of the seed divided over the years when the turf was being formed coming to about 10 s a year-varying in occasional years with the goodness or badness of the grass seed crop, and the demand for seeds. From what I have shown it seems clear that the Board of Agriculture is really spending the national funds in teaching agriculturists how to farm at a loss.

These conclusions are confirmed by an experiment I made in 1901 in the Big Haugh field, by which I lost about the rent of the land by adding dung and kainit to my ploughed-in turf. The manured section gave 15 tons of potatoes an acre, at an estimated cost for manure of $£_{2} 10$ s; the turf-manured section gave 14 tons 6 cwt., estimating the potatoes at $£ 2$ per ton, the result was that we lost $£ 12 \mathrm{~s}$, or about the rent of the land, from having used manures in addition to turf. This year, which I am told is an inferior potato year as compared to last year, the potatoes, grown on Hayhope Shank Field East, show a decline to 12 tons $18 \mathrm{cwt} 4 \mathrm{lb}$. on the manured section, and 12 tons $7 \mathrm{cwt}$. $1 \mathrm{lb}$. where

* As it might be supposed that a good turf could not be grown at Cockle Park, as it is a poor clay soil, I would refer the reader to Appendix III., giving results of experiments on the Abbotsley poor clay soil with one of my mixtures, which has there produced a fine turf in four years. 
the turf alone was relied on. It is interesting to note that these results had been attained under much more unfavourable circumstances, as, from certain requirements on the farm, the rotation system in the case of this field was altered to oats out of grass, turnips, barley, and turnips, part of the field this year being allotted to potatoes, so that they were preceded by a cereal crop, then a turnip crop, and then by another cereal crop. As neither of the two cereal crops had any manure, and the turnips some artificials only (see Appendix III.), the crop of potatoes, may be considered to be the most satisfactory evidence of the great value of turf as manure, and especially of its lasting effects. It will be interesting to observe how, on the potato section of Hayhope Shank field, the grass will compare with that on the section in turnips. As yet, no difference can be perceived in the Big Haugh field between the grass after potatoes and the grass after turnips. But it must be remembered that the Big Haugh potatoes were taken out of grass, while those of Hayhope Shank were the fourth crop of the series, which no doubt accounts partially for the shortness of the crop. A fifth crop, a cereal one, will be taken next year, when the grass seeds will be sown along with it, and this crop will be taken without manure, so that the system will be put to a very severe test. The soil of the field is what is known as very light land.

I now turn to the sheep experiment at Cockle Park, as regards which the same misleading form of experiment has been repeated. The diagram illustrating the effect of the transforming hand of the chemist is really rather amusing. We start, as the advertisements of nourishing foods for the human animal do, at an extremely low standard, and the diagram shows first the figure of a small, melancholy, attenuated sheep, and no wonder, as he has been kept in the no-manure plotpoor worn-out land, growing no less than about 84 per 
cent. of wiry bent. But this attenuated sample of what may be done by a dietary of this description has its use in magnifying immensely, by contrast, the sheep in the remaining eight compartments which have been stimulated by the use of artificial manures, at costs varying from $22 \mathrm{~s}$ to as high as $61 \mathrm{~s}$ an acre. The portly figures of these sheep, as shown in the diagram, with the various manures inscribed on their sides, are really most encouraging at first sight, and shows the results that may be attained by practically starving one sheep by keeping it on the toughest and poorest fare, and feeding others highly through the agency of costly manures applied to the soil. But how would it have been had the experiment been made on the Inner Kaimrig, which has carried a large sheep stock fed on a field full of dark green clover and kidney vetch, and which still, on November $1 \dot{2}$, presents a rich dark green appearance? I have no hesitation in saying that the attenuated sheep in Plot No. 1 of the Cockle Park experiments would have assumed a form as portly as his brethren on the manured plots, and yet on the Inner Kaimrig-originally the poorest field, on a poor to medium land farm-no manure, excepting some artificials with the turnips, has ever been used since the field was enclosed from the hill about 70 years ago, nor has any cake been fed on the land excepting some very trivial amount given to some rams kept in the field, and a few of the ewes drafted for sale-in fact, the amount of cake used on the whole farm is so small that the agriculturist quoted in my preface considered it to be practically none. But, for the benefit of the uninformed, I must add that it would convey an erroneous impression if I left him under the idea that my field had not been manured, and highly manured, and in a much more lasting form than the artificially-manured land at Cockle Park, on which the sheep experiments were made. For the Inner Kaimrig, as testified by the dark green herbage, has been heavily manured with nitrogen, partly taken from the 
atmosphere and partly from decaying turf; while the deep-rooting plants have deeply cultivated the land, bringing up food from depths hitherto untouched, and manufacturing, by the acids in their roots, inert into active plant food. The linmus has played its part, too, by converting into active plant food the dormant mineral constituents of the soil.

From what has been previously shown, it is evident that Professors Somerville and Middleton (who have managed the Cockle Park experiments) have simply remained in the experimental groove they inherited; and it will be satisfactory to the reader to find that they do not now seen to have one word to say in its favour as a complete method of investigation. Dr Somerville occupied the chair when I read my paper at Cambridge, and Professor Middleton was also present. As the reader will perceive, if he turns to the lecture, I stated in a more condensed form what I have treated in greater detail in this chapter, and showed that in all future experiments, as regards plants and animals, we require two sets of experiments-one with exhausted British soil, and the other with soil brought up to a good state of fertility by natural agencies, such as those employed at Clifton-on-Bowmont. When the time came for discussion neither $\mathrm{Dr}$. Somerville nor Professor Middleton, nor any one of the audience, had any objection to make to the very obvious points which I have just alluded to, so they may be held to have been ratified by the entire audience. Toward the close of my lecture one of the audience was overheard saying to a neighbour, "Your profession is at an end, anyhow." At first sight, indeed, this might seem to be so, but, as I pointed out in my lecture, the services of the chemist and the manure merchant will never be more thoroughly appreciated than they will be when our soils are brought into a high state of fertility by a proper admixture of humus.

From what I have previously shown, it is evident 
that every experimental farm should be divided into two compartments-the one consisting of exhausted British soil, like that of Cockle Park, and the other of soil brought into a good state of fertility by natural agencies. It could then be ascertained whether it would pay the farmer best to carry on his exhausted soil on the present system, and aided by artificial manures, or whether it would pay better to alter the farming system in the direction of that adopted by me, and reduce his artificial bill to a low ebb, or perhaps abolish it altogether, as I have this year done with one of my turnip crops. It seems obvious that if agricultural experiments such as I suggest are to be carried out, the present plan of employing what are called agricultural chemists inust be abandoned. What we require are practical farmers who have acquired that very moderate amount of chemical knowledge which constitutes the whole outfit of the existing so-called agricultural chemists, and which is all that is necessary on experimental farms of the kind I have suggested. Any intelligent farmer who bas been farming on his own account for, say, about ten years, and of about 35 years of age, could learn the necessary amount of chemistry in six months, and the farms would then have agricultural chemists with a thorough practical knowledge of agriculture, instead of, as at present, chemists who have either none, or the merest smattering of it. It must be considered further-and this is a most important point-that farmers would be encouraged to visit such farms, and would thoroughly rely on what they saw there, were the operations conducted by a practical farmer.

I think it advisable, in conclusion, to give my reason for asking the Government to take a lease of my Cliftonon-Bowmont farm. It was partly to save time, and partly because of the poorness of the land, its originallyexhausted condition, and the nature of the climate, which is both very dry, cold, and much exposed to 
severe winds. With my system of farming I have brought much of the land up to a good state of fertility-good enough to produce good crops without manure, other than that partly grown in the shape of turf and partly acquired from the atmosphere by natural means; but there is still enough land left which might be cultivated on the old system so as to form a comparison with the new system adopted. The farm consists of 1250 acres, and the high land portion of it would be valuable for experimenting as to the improvements that might be effected on such mountain grazings. The Government, it is true, might acquire similar land elsewhere, but before the required comparison between the old and the proposed system could be instituted many years would be required to pass bye-at least from 10 to 12 -before the farmer could be able to judge as to the respective merits of the two systems. The Board of A griculture sent an experienced official to report on the project, and he did so favourably, and I know that, besides, it was approved of by a prominent member of the Department; but nothing was done in the matter, which I now think is fortunate, as unless the farm were managed by a practical and skilful agriculturist, who had acquired the moderate knowledge of chemistry sufficient for the purpose, it could never be of the value it might become to the agricultural interests of these islands. I must not, however, be surprised at this want of action on the part of the Government in matters relating to agriculture, as its general policy seems to be to report, and do nothing but report. A Committee, as I have elsewhere shown, advised that a central seed testing station should be established where farmers could, for a small fee, get their seeds tested. This is a point of the greatest importance, and, indeed, absolutely essential to the system of farming I have initiated. The recommendation of the Committee was made in 1900 , but nothing whatever has been done to carry it into effect. Nor, I fear, will anything be done 
which will aid in at once saving the agricultural situation, and arresting the decline in the numbers of our rural population, till a statesman can be found patriotic enough to take charge of the Agricultural Department, and with enough energy and moral courage to compel the attention of the House of Commons to the requirements of British agriculture.

One word more. Any statesman can see for himself, by visiting Clifton-on-Bowmont, how great tracts of land now abandoned to pasture of a most worthless kind can be brought again under profitable cultivation with the aid of the system I have initiated; and how, therefore, the further abandonment of arable, with its consequent decline of our rural population, may be arrested. The more this subject is studied, the more clear does it become that the worst enemy of the rural population is the British Government, and it will continue to be so until it follows the methods for the advancenent of agriculture which have been adopted by all civilised Governments. 

APPENDICES. 



\section{APPENDIX I.}

\section{PAPER CONTRIBUTED BY MR. JAMES HUNTER,} agricultural SEED MERCHANT, chester.

TABLE showing the per centage of germination, weight per bushel, number of seeds in $1 \mathrm{lb} .$, number of germinating seeds in $1 \mathrm{lb}$., average price per $l b$. , and cost per million germinating seeds of the various Grass and Clover Seeds of the highest standard of quality and purity :-

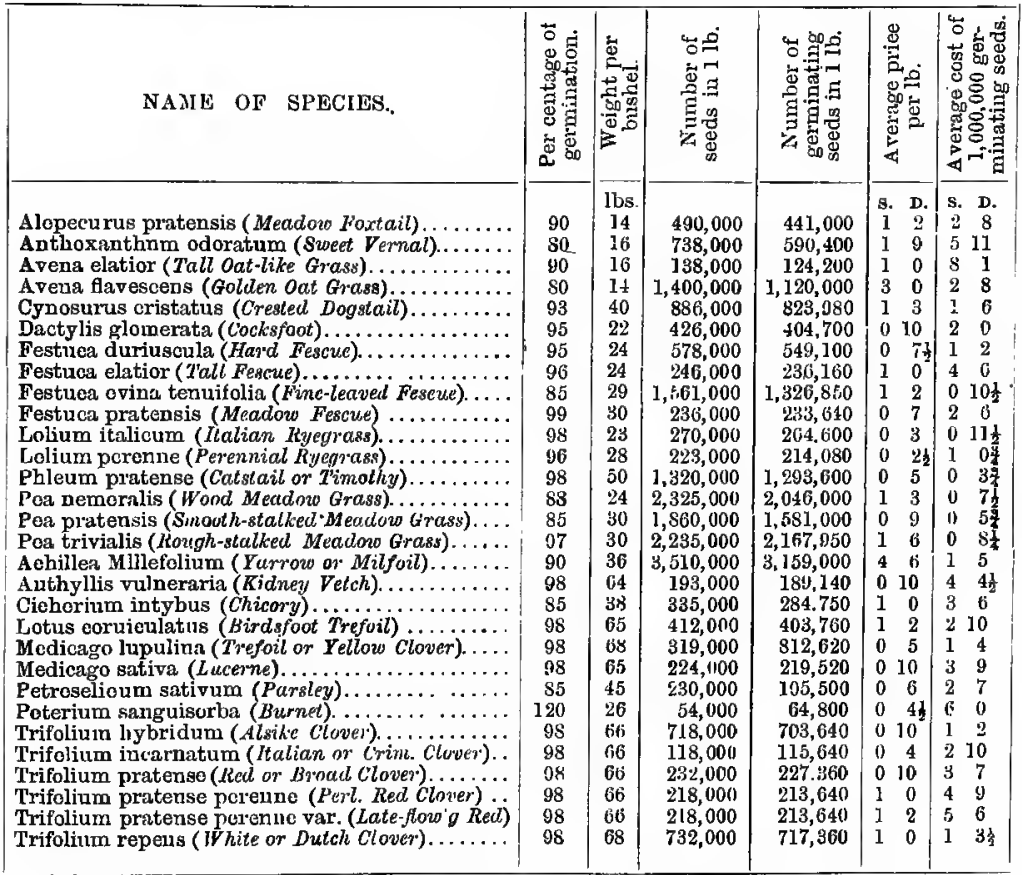

When seeds have been harvested under unfavourable conditions, or when there is a partial failure of crop of any species, the standard of germination for that species may be somewhat lower, and the price of the seed higher, so that due allowance must be made for such causes when they arise. It should also be borne in mind that these figures apply only to seeds of the highest standard of quality. Seeds of lower quality have a lower germination, are lighter in weight per bushel, have a greater number of seeds in $1 \mathrm{lb}$. weight, and, although cheaper by the lb., the cost per million germinating seeds is usually greater than for the best seeds. 
The quantity of Grass and Clover Seeds (of the highest standard of germination and purity) sufficient to sow an acre of each species, the number of germinating seeds per acre, the average price per $l b$, and the average cost of the seeds per acre :-

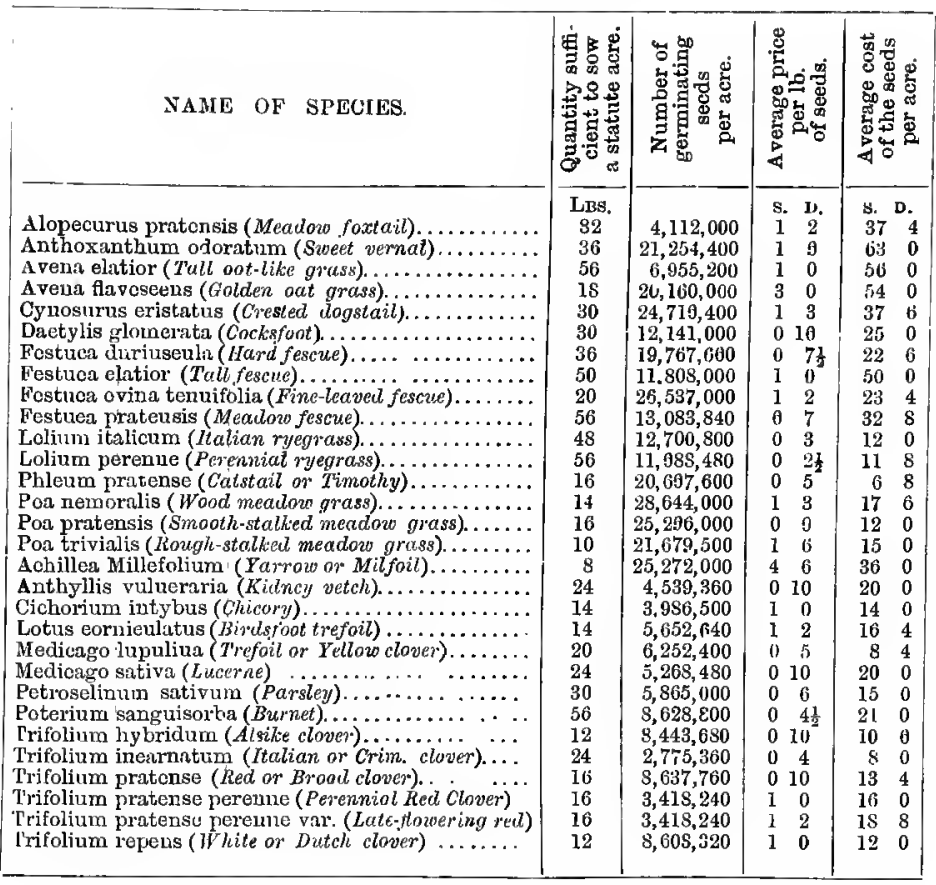

The quantity of any species of grass required to sow an acre depends (1) on the size and weight of the seeds (these vary considerably in the different species-e.g., Avena elatior has 138,000 seeds in a lb., while Poa trivialis has over two millions); (2) the size of the plant, and its surface-covering capacity. Grasses of large growth, such as cocksfoot, or those of spreading habit like Poa trivialis, require fewer plants to cover an acre than those of small or upright habit of growth, such as Festuca ovina tenuifolia or Paa nemoralis. It is necessary, therefore, to take these matters, as well as the pricc of the seed, into consideration, if economy in seeding is to be practised, as the seed that is the lowest in price per lb. is not the chcapest per acre, nor is the sced that is highest in price per lb. the dearest. 
Estimate of the relative productiveness (quantity of grass produced in one season I of various species of Grasses, when grown on soils and under conditions best suited to the different species, arranged in the order of their productiveness :-

\begin{tabular}{|c|c|}
\hline & $\begin{array}{c}\text { Estimated } \\
\text { per centage of } \\
\text { productiveness. }\end{array}$ \\
\hline Dactylis glomerata (Cocksyoot). & 100 \\
\hline Festuca elatior ( Tull fescue) ... & 100 \\
\hline Avena olatior (Tall out grass).......... & 100 \\
\hline Phleum pratcuse (Timothy) ............ & 75 \\
\hline Lolium italicum (Italian ryegrass)... & 75 \\
\hline Lolium perenne (Perennial ryegrass).... & 70 \\
\hline Festuca pratensis (Mecdow fescue)...... & 70 \\
\hline Alopecurus pratensis (Meadov foxtail)....... & 70 \\
\hline Poa trivialis (Rough-stalked meadow grass). .... & 60 \\
\hline Avena flavesceus (Golden oat grass)........... & 55 \\
\hline Poa pratensis (Smooth-stalked meadow yrass). & 55 \\
\hline Festuca duriuscula $($ Har d fescue $) \ldots \ldots \ldots \ldots \ldots$ & 50 \\
\hline Luthoxanthum odoratum (Sweet verncel) .... & 50 \\
\hline Cynosurus cristatus (Crested dogstail)..... & 45 \\
\hline Pon nemoralis (Wood meadow grass)......... . & 45 \\
\hline Festuca ovina tenuifolia (Fine-leaved fexcute)... & 40 \\
\hline
\end{tabular}

The recorded weights of the produce of small trial plots of grasses, madc for the purpose of ascertaining their relative productiveness, show such diversity of results (probably owing to the smallncss of the plots and the varying conditions of soil, climate, \&c.) that they cannot readily be made use of for practical purposes. As, however, a general idea of the weight of herbage produced in one season's growth by each of the grasses used in laying down land to grass is necessary to the proper selection of seeds of the most profitable kinds, the above estimate is submitted, and, while absolute accuracy is not claimed for it, yet it may probably be accepted as presenting a fair view of the relative amount of grass each species is capable of producing when grown under the most suitable conditions of soil, climate, moisture, \&c. 
Grasses arranged in the order of their cost for seeds required to sow an acre :-

\begin{tabular}{|c|c|c|c|c|}
\hline & 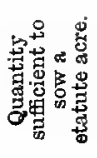 & 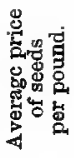 & 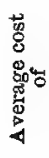 & 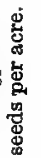 \\
\hline & LBS & 8. D. & s. & D. \\
\hline Phleum pratense (Timothy).......... & 16 & & 6 & 8 \\
\hline Lolium perenne (Porennial ryegrass). . & 56 & $2 \frac{2}{3}$ & 11 & 8 \\
\hline Lolium italicum (Italian ryegrass)............ & 48 & & 12 & 0 \\
\hline Poa pratensis (S mooth-stalked meadovs grass).... & 16 & 0 & 12 & 0 \\
\hline Poa trivialis (Rough-stalked meadono grass)...... & 10 & 1 & 15 & 0 \\
\hline Poa nemoralis ( Wood meadow grass)....... .. & 14 & 1 & 17 & is \\
\hline Festuce duriuscula ( Hard feseue)... ... .. & 36 & 7 & 22 & 6 \\
\hline Festuca ovina teuud tolia (Fine-leaved feseue) ... & 20 & 12 & 23 & 4 \\
\hline Dactylis glomerata (Cocksfoot)............ & 30 & 010 & 25 & 0 \\
\hline Festuca prateusis (Meadnw fescue)... .... & 50 & 07 & 32 & 8 \\
\hline Alopecurus pratensis (Meadow foxtail). ...... & 32 & 1 & 37 & 4 \\
\hline Cynosurus cristatus (Crested dogatail) $\ldots$. & 30 & l & 37 & 6 \\
\hline Festuca elatior (Tall fescue) . . . . . . . . . . . . & 50 & 1 & 50 & 0 \\
\hline A vcur flavescens (Golden oat grass)............ & 18 & 3 & 54 & ) \\
\hline Avena elatior (Tall oat grass) $\ldots \ldots \ldots \ldots \ldots$ & 56 & 1 & 56 & 0 \\
\hline Anthoxanthum odoratim (Sweet vernal)........ & 36 & 1 & 63 & 0 \\
\hline
\end{tabular}

The above Table is intended to serve as a guide to the economical use of grass seeds. When making a selection of grasses, the following points should each receive due consideration :-

(1) Productiveness.

(2) Suitability of the species for the soil and climate, and for the purpose for which the sceds are required.

(3) Cost of the seeds.

From the Table of "Estimate of Productiveness," given on page 131, it will be seen that some grasses are capable of producing more than double the quantity of herbage that other species can produce, while from the above Table of the cost of seeds required to sow an acre, it will be observed that the variation in the cost of different seeds is very great. It must also be borne in mind that some of the species whose seeds are most expensive are inferior to others whose seeds are far cheaper. The price of seed depends on the cost of its production, and not on its real value or usefulness. Careful consideration of these matters is therefore necessary to a proper seleetion.

If the information given in these two Tables is conjointly considered, it will not be difficult to select grasses that are at once the most profitable and least expensive. Taking, for example, Phleum pratense (Timothy), which is the lowest-priced secd in the above Table, it will be found on reference to the proper Table that it ranks high as regards productiveness, so that this species readily takes its place as the cheapest grass seed, and therefore worthy of extensive use. On the other hand, Anthoxanthum odoratum (Sweet Vernal), the most expensive seed in the above Table, will be found to be one of the least productive (and at the same time a grass of inferior quality), so that it may be considered as unworthy of notice. 


\section{GRASS MIXTURES SUGGESTED BY MR. JAMES HUNTER, OF CHESTER.}

Selection of Grasses and Clovers for Permanent Pasture on poor dry soils, or in a dry climate subject to drowght:-

\begin{tabular}{|c|c|c|c|c|}
\hline & 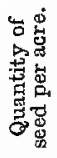 & 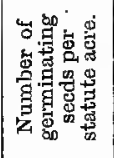 & 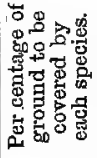 & 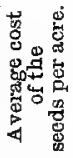 \\
\hline 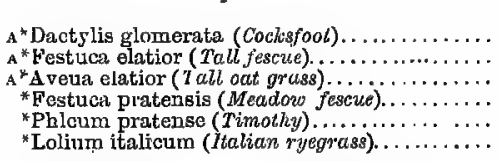 & $\begin{array}{c}\text { L BS. } \\
5 \\
3 \\
3 \\
5 \\
2 \\
2 \frac{1}{3}\end{array}$ & $\begin{array}{r}3,237,600 \\
708,480 \\
372,600 \\
1,168,200 \\
2,587,200 \\
661,500\end{array}$ & $\begin{array}{r}18 \\
5 \\
5 \\
7 \\
6 \\
3\end{array}$ & $\begin{array}{cc}\text { S. } & 1 \text {. } \\
6 & 8 \\
3 & 0 \\
3 & 0 \\
2 & 11 \\
0 & 10 \\
0 & 74\end{array}$ \\
\hline 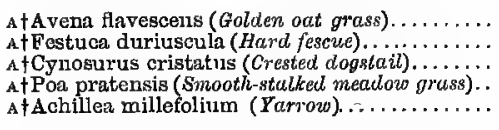 & $\begin{array}{l}0 \frac{1}{2} \\
2 \\
0 \frac{1}{2} \\
1 \\
0 \frac{1}{4}\end{array}$ & $\begin{array}{r}560,000 \\
1,098,200 \\
411,990 \\
1,581,000 \\
7 \times 9,750\end{array}$ & $\begin{array}{l}3 \\
5 \\
2 \\
5 \\
3\end{array}$ & $\begin{array}{ll}1 & 6 \\
1 & 3 \\
0 & 7 \frac{1}{2} \\
0 & 9 \\
1 & 1 \frac{1}{2}\end{array}$ \\
\hline $\begin{array}{l}\text { †Trifolium hybridum (Alsike clover) ........... } \\
\text { †Trifolium pratense perenue var. (Late-flower- }\end{array}$ & I & 703,640 & 4 & 010 \\
\hline 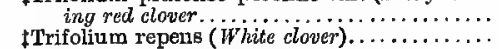 & $\begin{array}{l}2 \\
1 \frac{1}{3}\end{array}$ & $\begin{array}{r}427,280 \\
1,076,040\end{array}$ & & $\begin{array}{l}2 \\
1\end{array}$ \\
\hline \multirow[t]{2}{*}{ 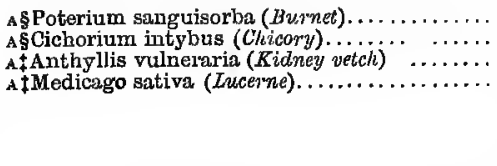 } & $\begin{array}{l}4 \\
2 \\
2 \\
2\end{array}$ & $\begin{array}{l}259,200 \\
569,500 \\
378,280 \\
439,040\end{array}$ & $\begin{array}{l}4 \\
8 \\
5 \\
5 \\
-22\end{array}$ & $\begin{array}{l}1 \\
2 \\
1 \\
1\end{array}$ \\
\hline & $42 \frac{1}{4}$ & $I 7,029,500$ & 100 & 33 \\
\hline
\end{tabular}

* Layge Grasses.

† Small Grasses, and Yarrow for filling up the bottom.

† Clovers.

Deep-rooting plants.

All the spccies marked a are drought-resisting, aud most of them continue to grow and thrive in very dry weather. 
Selection of Grasses and Clovers for Permanent Pasture on the best class of soils, in a moist climate, or where the average rainfall is 28 inches or more:-

\begin{tabular}{|c|c|c|c|c|}
\hline & 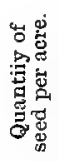 & 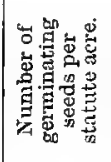 & 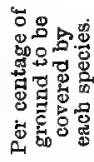 & 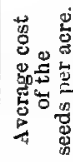 \\
\hline 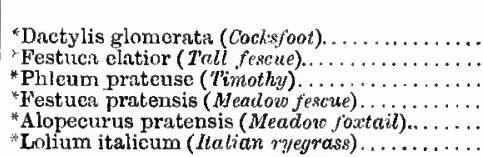 & $\begin{array}{l}\text { LBB. } \\
7 \\
3 \\
3 \\
8 \\
4 \\
2 \frac{1}{2}\end{array}$ & $\begin{array}{r}2,832,900 \\
708,480 \\
3,880,800 \\
1,869,120 \\
1,764,000 \\
601,500\end{array}$ & $\begin{array}{r}18 \\
1 \\
12 \\
14 \\
12 \\
4\end{array}$ & $\begin{array}{lc}\text { S. } & \text { D. } \\
5 & 10 \\
3 & 0 \\
1 & 3 \\
4 & 8 \\
4 & 8 \\
0 & 71\end{array}$ \\
\hline $\begin{array}{l}\text { †Poa trivialis (Rough-stalked meadow grass).... } \\
\text { † Festuca duriscula (Hard fescue) } \ldots \ldots \ldots \ldots \ldots \ldots \\
\text { †Aehillea millefolium }(\text { Yarrow }) . \ldots \ldots \ldots \ldots \ldots\end{array}$ & $\begin{array}{l}1+ \\
1 \\
01\end{array}$ & $\begin{array}{r}2,709,940 \\
549,100 \\
789,750\end{array}$ & $\begin{array}{l}7 \\
3 \\
3\end{array}$ & $\begin{array}{lr}1 & 10 \frac{1}{2} \\
0 & 7 \frac{1}{2} \\
1 & 1 \frac{1}{2}\end{array}$ \\
\hline 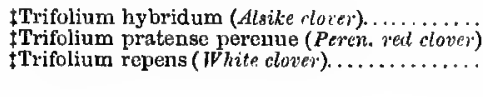 & $\begin{array}{l}1 \\
3 \\
2\end{array}$ & $\begin{array}{r}703,640 \\
640,920 \\
1,434,720\end{array}$ & $\begin{array}{rr}4 & \\
8 & \\
9 & \\
- & 21\end{array}$ & $\begin{array}{lr}0 & 10 \\
3 & 0 \\
2 & 0\end{array}$ \\
\hline & 36 & $18,544,370$ & 100 & 306 \\
\hline
\end{tabular}

"Largc-growing Grasses.

+ Small-growing Grasses, and Yarrow to fill up bottom.

‡lovers. 
Note by Mr. James Hunter on more Seed being required when the Land is not in fine tilth.

The capacity of even the small delicate-seeded grasses for establishing themselves under unfavourable conditions of soil, \&c., is remarkable, and, in my opinion, sowing on rough land means chiefly a loss of a portion of the seed sown, but it does not prevent the remaining portion from ultimately doing well. My views are these :-If sown on a fine tilth, and under perfect conditions as regards moisture and heat, every seed having germinating capacity may be expected to germinate and establish itself, if not interfered with by birds or otherwise. If sown on soil not properly pulverized, a small and delicate grass seed falling on the outside of a clod might germinate, but might be scorched and killed by a day or two's hot sunshine and drought before it could obtain root-hold. If the same seed fell in a hollow, and was covered by a clod, it would have no chance of germinating, being too deeply covered. In both these cases the seeds are practically lost, and the outcome of the matter is that, while with a fine tilth and suitable conditions as regards moisture and warmth, a perfect germiuation from all the seeds sown may be immediately obtained, sowing on rough land cannot possibly give such good results, as probably one-half of these fine seeds have fallen where they cannot succeed, and an extra allowance of seed should be sown on rougb land to compensate for the seeds that will be lost.

Large-seeded grasses, such as cocksfoot, meadow and tall fescues, and ryegrasses, have naturally greater staying powers than the smallseeded grasses and the clovers.

It must be a question for the agriculturist to decide whether it will suit him best to prepare his land perfectly and sow less seed, or sow on rougher land and use more seed. In many cases it is impossible to prepare the land perfectly, and there is nothing for it but to do the best one can in this respect, and not stint the seed when the land is rougher than it should be at the time of laying down. 


\section{APPENDIX II.}

On some Wotes on the Seed Trade and Grass Seeds supplied by Mr. Jas. IInter, Agricultural Seed Merchant, Chester.

When my late friend, Mr. Faunce de Laune of Sharsted Court, Kent, wrote, in 1882, his paper on " Laying Down Land to Permanent Pasture"*-a paper which initiated all the important results that followed it both in the seed trade and in the selection of seeds by agriculturists, as well as in the cleaning of seeds, which resulted in thistles and weeds being largely diminished - the grass and seed trade in this country was in a most extraordinary condition, and illustrates the need, to which $I$ havc repeatedly called attention, for agricultural schools. For, at the time my friend wrote, Mr. James Hunter points out that "great ignorance of the permanent grasses prevailed both amongst seedsmen and agriculturists. Seedsmen knew little either of the species of grasses or their seeds, and agriculturists still less. When land was laid down to permanent grass a 'mixture' of seeds was ordered, and the agriculturist accepted whatever was supplied, as he had no knowledge to enable him to look after his own interests. Such being the case, adulterated seeds, and seeds of very inferior quality, were freely sold without any complaint being made by the purchasers; and, as the price of different grass seeds varies considerably, the cheaper were used in excessive quantity. Thus ryegrass seed, which is always low-priced, was largely used in permanent grass mixtures, and it was also the adulterant in the cases of meadow fescue, cocksfoot, \&c. It might readily happen, therefore, that, owing to the low quality and inferior germination of the grass seeds (other than ryegrass) used, and the large proportion of ryegrass (which is usually of good germination) in the mixture, nine-tenths of the grasses in a pasture might be ryegrass. To Mr. Faunce de Laune is due the great credit of being the first to discover and draw attention to this great evil, and his efforts have had most beneficial results, not only in directing attention to the proper species to grow, but in creating a demand for pure seeds, which is now fairly supplied. It must not, however, be supposed that the sale of bad seeds bas been stopped. A perusal of the annual reports of the consulting botanist to the Royal Agricultura Society of England will show that this is still too common. But with ordinary care on the part of the buyer, there is now no difficulty in procuring pure seeds." Mr. Hunter then gives the following extract

* "Journal of the Royal Agricultural Society of England." Second Series, Vol. XVIII. 1882. John Murray, London. 
from his price-list, which, in his opinion, offers an easy and safe method of obtaining good seeds :-

"To enable purchasers to have their seeds analysed and tested before the time of sowing, any seeds required will be dclivered carriage free to the purchaser, so that sumples for analysis may be taken from the bulks while they are in the possession of the buyer. This method is more satisfactory than that of testing a sample received from the seed merchant before purchasing, as it excludes all doubt about the identity of the seed analysed. In the event of any kind of seed not fulfilling, in every particular, the guarantee of purity, genuineness, or per centage or germination stated in this catalogue, such seed may be refused, and returned at the expense of the seller, who will also in sucb a case pay the consulting botanist': fee."

It is hardly necessary to say that, with such a system at the command of the purchaser, it is now his own fault if he does not put down good seed.

Mr. Hunter deprecates the use of such a large quantity of clover seed as is commonly sown when laying down land to permanent pasture. He says that it has been customary to sow about $9 \mathrm{Ib}$. of clover, and a farmer in Scotland who has laid down much land to grass tells me that $12 \mathrm{lb}$. to $14 \mathrm{lb}$. are often sown. Mr. Hunter advises $5 \mathrm{Ib}$. of the best clover seeds, and says that equally good results will be obtained as from sowing a larger quantity. I generally use $5 \mathrm{lb}$., and find this ample; and, on showing a field of temporary grass on which that quantity had been sown to a number of farmers, they could hardly believe that so little seed had been used.

As regards Sinclair's estimate of the number of seeds in a lb., Mr. Hunter observes that this cannot now be accepted, as in former days there would be a great difficulty in obtaining such samples as can now be produced. "The number of seeds," writes Mr. Hunter; " in a Ib. depends entirely on the quality of the sample you choose. A sample of light undressed grass seed will give twice or three times the number of seeds to the lb. that a perfectly-dressed sample of heavy ripe quality will do. To insure accuracy in this matter, I had all the seeds in my table carefully counted, using only samples of heaviest weight and purest quality, and these figures are now generally adopted." 


\section{APPENDIX III.}

Outer Kaimrig Experiment,-The experiment with the Outer Kaimrig field began in 1890, and the particulars are given on page 29. The mixture used in 1899 was-

Cocksfoot

Tall Fescuc

Tall Oat-like Grass .

Hard Fescue

Crested Dogstail

Golden Oat Grass

Rough-stalked Meadow Grass - 1

Late-flowering Red Clover
Lb.

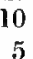

5

5

2

1

1

1

49 lb. per acre.

White Clover

Alsike Clover

Chicory

Burnet

Kidney Vetch .

Yarrow

Sheep's Parsley

Field Parsnip
Lb.

2

2

4

8

3

1

1

1

Cnst of seeds, $\mathbb{E l} 19 \mathrm{~s}$ ld, or under 8s a year.

The parsnip was put down as an experiment, but $I$ have since formed the opinion that chicory is the more suitable plant, and is superior to the parsnip. The pasture, the seeds for which were sown May 8, 1899 , with oats, which proved a good crop, has given much satisfaction, and kept the following stock in $1900:-$ From April 27 to June 13, 60 half-bred ewes and twin lambs; from June 13 to July 27 , 80 ewes and twin lambs; from July 30 to August 21, 180 lambs; from August 21 to September 1, 100 ewes; from October 5 to November 10, 60 ewes. The ewes and twin lambs were increased from 60 to 80 , as 60 ewes and their double lambs proved quite insufficient to keep the grass down. The field latterly could have kept much more stock, but bas beels lightly grazed towards the end of the season, as it is first year's grass. I regard this field as an interesting proof of what may be done with the vast areas of run-out and poor lands in these islands. The field is the furthest out one on the farm ; it is extremely exposed, and bas no plantation or hedge to protect it; its elevation is from about 700 feet at the foot of the field to 800 at the top. It had been taken out of the bill about seventy years ago, and worked on the five-course shift, and has never been manured since, excepting with some artificials with the turnips, and the manure (a most important exception, I admit, if we consider all its effects) of a. good turf grown with deep-rooting grasses and plants. Those who have not seen the field cannot believe in the amount of stock it bas carried, but the explanation simply is that, if you grow a full supply of the most deep-rooting plants, you tap deptbs quite out of the reach of the shallow-rooting ryegrass, and certainly add about 30 per cent. to the available rootage area of the field; the large supply of plants of rapidly-productive powers does the rest. 
Bank Field Experiment. -The Bank field consists of 27 acres, rather more than half of which is poor, stony, and exposed, and in some parts very steep land. The remainder consists of fair medium soil for that part of the country. For the last nineteen years 24 acres of the field have never been manured, excepting with the artificials used with the turnips. The remaining 3 acres have once-some years ago-had some farmyard manure, and the seed mixture used in 1900 was-

Cocksfoot
Tall Fescue
Tall Oat-like Grass
Rough-stalked Meadow Grass -
Late-flowering Red Clover
White Clover

\begin{tabular}{r|r} 
Lb. \\
14 \\
7 \\
7 \\
1 \\
2 \\
2
\end{tabular}

Lb.

Alsike Clover

Yarrow

Burnet

Kidney Vetch -

Clicory

49 lb. per acre. Cost, $£ 1$ 19s 5 d.

This mixture, I think, is an improvement, as, at about the same cost, there is supplied a larger quantity of the most hardy, drought. resisting, early, and productive grasses. It is a safe mixture, because the seeds of the large grasses are much less liable to fail than those of the smaller ones, and it is calculated to leave a greater quantity of vegetable matter for the succeeding crops. Later observation of the suitability of the golden oat grass to this description of soil has suggested the use of $\frac{1}{2} \mathrm{lb}$. or $1 \mathrm{lb}$. per acre. Aftcr the first ploughing of the grass and our usual rotation of cereal and turnip crops, it has becn found that the fineness of the tilth permits the use of a smaller quantity of seeds than used in 1900 for the Bank field; consequently, the Inner Kaimrig and Harewells fields were laid down in 1903 with only $10 \mathrm{lb}$. cocksfoot, $5 \mathrm{lb}$. tall fescue, and $5 \mathrm{lb}$. tall oat grass, together with the other usual seeds, and thus far the results are entirely satisfactory. Farmers, I observe, have a prejudice against grasses which, like cocksfoot and tall fescue, may become coarse, but such grasses are either fine or coarse, as the farmer is intelligent or uninformed. The intelligent farmer sows plenty of the secds, and grazes the grasses so that they may be kept in a constant succession of joung leaves; the nninformed farmer puts down a small quantity of the seeds, with the result that each plant grows like a bulrush, whereas by crowding the plants each one becomes small and fine. We have a pasture of about 4 acres at head of Bowmontside field which was laid down in 1887 with the intention of its being taken up again with the rest of the field, but it was fenced off and left in permanent pasture, as the land was so steep. The mixture consisted of-

Cocksfoot

Perennial Ryegrass

Hard Fescue

\begin{tabular}{r|l} 
Lb. & \\
16 & Perennial Red Clover \\
4 & White Clover \\
2 & Alsike
\end{tabular}

Lb.

2 Alsike

4

At a cost of $£ 12 \mathrm{~s} 5 \mathrm{~d}$.

This pasture has done well, and always remained fine, and even when 
let up to a considerable extent, so that part of the pasture was a mass of cocksfoot heads, the grass and flowering stems were not coarse.

Returning to the Bank field experiment. As our previous hay crops had been very heavy-sometimes about 3 tons an acre-I adopted the following treatment in order to lessen the hay crop, and so favour the subserquent pasture. After harvest, and rolling the field, it was stocked for five weeks with 4 hoggs an acre and 11 calves for the entire field, and from first week in April to May 20 with never less than 2 cwes and twin lambs per acre, and often 3 ewes and twins. The field was then shut up for hay, which is estimated at about 2 tons an acre, and would have been certainly much more had it not becn for a drought so severe that shecp absolutely refused to go up to the top of onc of our hills, while the tails of the peacocks have fallen out far earlier than usual. In the hay there is very little chicory, and hardly any seeding stems, and, as the chicory is composed almost entirely of young leaves, it is thought that it will not cause the hay to be dusty, which is the great evil arising from fully-developed chicory when used for hay. The produce from the coarse grasses is as fine as could possibly be desired. In the judgment of a visitor, whose opinion is to be valued, it would be impossible to produce a finer sample of hay. With the exception of about 3 ncres, only once manured with dung about six years ago, the field has never been manured since 1887 , in the ordinary sense of the word; and yet, from the colour and luxuriance of the clover and kidney vetch, the agriculturists who saw the field thought it had been dressed with nitrates, and so it had been most fully from the atmosphere. The fact is that with our system no manure is required over and above that supplied by a deeply-rooted turf, the nitrogen collected from the atmosphere. by our abundant clover and kidney vetch, and the artificials used with the turnip crops; and this has now been amply proved by stock and crops all along the line. In the case of last year's (1901) drought, when there was such a general failure of grass, and especially of clover, the Bank field had a most luxuriant appearance all the season through, and the results clearly prove that, with the aid of the new farming system, the farmer may regard the worst drought with absolute indifference. From October 1, 1900 , to October 1, 1901, the value of grazing and hay attained was estimated by us at $£ 73 \mathrm{~s}$ an acre. Our estimate has been referred to a tenant-farmer, who is cmployed as a valuator, and his estimate comes to rather more-£i $7 \mathrm{~s} 6 \mathrm{~d}$ an acre."

From October 2, 1901, to October 1, 1902, the field has been stocked as appended, and $I$ purposely allowed it to be so much later in the autumn and winter than was judicious in order to see how the now mixture would stand the roughest treatment; and the effect of this, as might have been anticipated, has been a decline of the clover, though this seems to be recovering, and there is now an abundant feed of grass in the field, which is still stocked with 60 ewes. The list of the stock is as follows :- 
From October 1, 1901, to. December 31, 1901, 4 ewes per acre, with the assistance of one cartload of either cabbages or turnips per day for the field.

From March 15 to May 24, 1902, 3 ewes and single lambs per acre, with the assistance of two cartloads of turnips per day for the field.

From May 24 to July 28, 1902, $2 \frac{1}{2}$ ewes and single lambs per acre.

From July 28 to October $1,1902,3$ ewes per acre.

From May 1, 1902, to June 10, 5 cattle.

From June 13 to September 4, 2 horses.

Experiments in Alghope Field. - This field was laid down with a crop of barley in 1884 by the now tenant, the mixture consisting of ryegrass and clover, with a very small quantity of cocksfoot. In 1896 , or twelve years later, about 16 acres of the central portion of the field was ploughed, and the turf laid over as flat as possible. In 1897 it was sown with rape, which was eaten off by sheep. In 1898 it was sown with oats (which proved to be a fair crop), and

\begin{tabular}{lr|lr} 
Cocksfoot & Lb. & Lb. & I arrow \\
Tall Oat Grass & 14 & Sheep's Parsley & 1 \\
Hard Fescue & 4 & White Clover & 2 \\
Crested Dogstail & 2 & Wate-flowering Red Clover & 2 \\
Burnet & 1 & Catike Clover &,- 1 \\
Chicory & 8 & Alsike
\end{tabular}

After the first ploughing the reversed turf was not stirred, but the ground merely barrowed. In 1899, in consequence of the fencc having been taken down between the experimental portion and the northern portion of the field, which had been laid down to grass after a course of cropping, the stock ncglected the former, and hence the wild grasses in the reversed turf got too much ahead, and injured the newly-sown grasses; and this, of course, interfered with the experiment. In 1900, however, the newly-sown grasses showed much better, and the stock distributed itself evenly over both portions of the field, and the experimental portion has much improved. In 1901 the field is to be entirely grazed with cattle till the autumn, or until the grasses have shed their seeds. So far as we can see, the field seems to show that by simply reversing the turf of an old pasture it may be thus cheaply laid down to superior grasses at a very moderate expense, as, after ploughing once, nothing further is required except harrowing and rolling. It is, of course, essential that tall strong grasses like cocksfoot, tall fescue, and tall oat grass should be frecly used, as these will overcome the grasses and weeds existing in old pasture to a very great extent, if not entirely, though the latter is a point that remains to be proved. I omitted tall fescue in this experiment in order to lesscn the cost of seed.

It was very noticeable how superior the end rig of the experiment was to the rest of the field, and this evidently arose from more seed having fallen there (from the sowing machine slowing). This con- 


\section{Experiences up to the end of October, 1904.}

firms, of course, what is well known, that the rougher the ground the more is the seed required. It yet remains to be proved whether, in such cases, it will pay better to put down more seed, or rely on the difference being made up by allowing the grasses to seed. I regard this experiment as one of great importance, as, for various reasons, it would often pay better to reverse the sod, and lay down after a crop of rape, than to put the land through a course of cropping. The above alluded to central portion of Alghope field has turned out to be as satisfactory as could be expected, taking into consideration that the lifting of the fence injured the experiment. In $1902 \mathrm{I} \mathrm{dug}$ up some turfs of it in order to compare them with turfs taken from the section laid down in 1884, and found much more rootage in the former, and that the turf was thicker. Altogether, the pasture was much improved by the operation, and is now free from moss, while the pasture of 1884 is thick with it, and in a most unsatisfactory condition in consequence. In the south-west corncr of the 1884 section I have experimented this year (1904) by reversing the turf, harrowing 'it, and sowing grass secds, and clover, and rape on one portion, and similar seeds with buckwheat on the other. So far as I can see at present, the buckwheat will be much more favourable to the grass than the rape, as the former disintegrates the surface soil thoroughly, and so leaves it in a much more open condition than is the case on the rape section, the surface soil of which is quite hard. Next year, on the 1884 section, 1 am going to experiment by ploughing up the turf thinly, turning it back again, and sowing cocksfoot, clover, chicory, burnet, and kidney vetch, and some golden oat grass over the intersticcs. This, I think, will be successful, and, should it be so, the idea will be of great value to those who have poor mossy pastures which they wish to improve at small expense. I am in hopes that it will succeed, from observing the immense improvement that took place in the mossy slopes of the terraces here, when the turf was simply lifted and replaced after levelling the inequalities in the slopes. Still no grass seeds were sown, nor manures applied, and yet there was an immediate and great improvement in the slopes, and the moss quite disappeared.

Success of the Clifton Park System of Grass Growing on Poor Clay Soil. - At the meetings of the Royal Agricultural Society of England, held at Park Royal, London, in 1903 and 1904, the Cambridge University Department of Agriculturc exhibited turfs from their expcrimental pastures at Abbotsley, Hunts, and the Department made the following reports :-

June, 1903.

" Four turfs from Abbotsley, Huntingdonshire, showing pastures produced on stiff clay soil by various 'seeds' mixtures. 'The seeds were sown about June 1st, 1900, and 10 cwt. basic slag per acre was applied in the following autumn.

"Details of the seeds mixtures will be found in the Fourth Aunual Report of the Department. The turfs exhibited are (a) from Plot I., 
a mixture of perennial ryegrass and clovers-47 lb. seeds costing $14 \mathrm{~s} 6 \mathrm{~d}$ per acre, moderately satisfactory; $(b)$ from Plot V., a mixture of permanent grasses and clovers-38 lb. seeds costing 45s 9d, moderately satisfactory; (c) from Plot VII. same as Plot V., but sainfoin in place of clovers-50 lb. seeds costing 46s, not satisfactory; (d) Plot VIII. sown with Elliot's 1895 mixture-45 $\frac{1}{2}$ lb. seeds costing 39s 6d, most satisfactory. On the poor clay soil of Abbotsley eight different mixtures have been tried, and at the present time Elliot's is much the most promising. The soil is now evenly covered with herbage, which looks as if it would be permanent. None of the other mixtures have, so far, produced a close turf."

June, 1904.

"Set of seven turfs from Abbotsley, Hunts, showing the pastures produced in the fourth season by varions mixtures of seeds sown in 1900, viz.:-1, Mixture of ryegrass and clovers, costing $14 \mathrm{~s} 6 \mathrm{~d}$ per acre; 2 , mixture of perennial ryegrass and the chief pasture grasses and clovers, costing $28 \mathrm{~s}$ per acre; 3 , a mixture of the chief pasture grasses and clovers, without perennial ryegrass, costing $30 \mathrm{~s} 6 \mathrm{~d}$ per acre; 4, one of Elliot's special mixtures, costing $39 \mathrm{~s} 6 \mathrm{~d}$ per acre. All the above manured with $10 \mathrm{cwt}$. basic slag per acre in autumn 1900. No. 4 reprcsents much the best of the pastures."

No. 4 mixture was that used by $\mathrm{Mr}$ Elliot in 1895 for laying down 25 acres poor land, and now in the fourth season. The turf from this mixture now exhibited is labelled as follows:- "Much the best of the pastures, a close even sward, closely grazed by stock."

\section{Mixture of Drought-resisting Plants for Bare Rocky Surfaces.-} The reader will remember that (vide page 56) Arthur Young has recommended for chalk soil a mixture of yarrow, burnet, trefoil, white clover, and chicory, so that the pasture would be formed of plants not one of which is a grass plant. On full consideration, I think it probable that Arthur Young is quite right in limiting his selection for thin lands to plants that he was sure would flourish on them, and as there are often, on hill lands especially, gravelly slopes of thin soil, on which grasses at once dry up in a drought, I have corresponded with Mr. James Hunter as to the proportions for a mixture composed entirely of drought-resisting plants other than grass, and he has sent me the following mixture, to which, howevor, he has added one grass. The mixture is as follows :-

\begin{tabular}{lr|lr} 
& Lb. & Lb. \\
White Clover & 4 & Chicory & 4 \\
Kidney Vetch & 6 & Ribgrass & 4 \\
Yarrow & 1 & Crestcd Dogstail & 3 \\
Burnet & 8 & &
\end{tabular}

Total, 30 lb. per acre.

Such a mixture might be sown on the steep, gravelly banks of a field, and the remainder of the land sown with whatever mixture was most suitable.

Two acres of the Sheerbrough field, where the soil is shallowly 
distributed over a rocky surface, were sown in 1900, and this year (1904) the results shown are most satisfactory, and a fair amount of grazing has been attained, where almost nothing could have been expected from an ordinary grass mixture.

Success of the Clifton Park System in Growing Potatoes without Mariure.-I now pass to an experiment with potatoes in the case of the Haugh field of 27 acres-a shingly-spotted haugh on the banks of the Bowmont-which, in our early experience of the farm, always suffered extremely from drought. It was laid down in 1893 with one of my mixtures containing chicory, burnet, \&e., and was ploughed up at the close of last year (1900), and partly sown in 1901 with potatoes, and partly with tuinips. The former, which were manured with dung and kainit, at an estimated cost of $t 210$ s an acre, gave 15 tons per aere. Those which had no manure gave 14 tons $6 \mathrm{cwt}$. Estimating the potatoes at $£ 2$ per ton, the result was $£ l$ 2s in favour of the unmanured portion. In the case of the Balderston farm potato experiments near Linlithgow in 1903 no less than 20 tons of dung per acre and $7 \frac{1}{2}$ ewt. of "artificials" per acre were used. The Up-to-Date variety gave 10 tons $18 \mathrm{cwt}$. $6 \mathrm{lb}$. The same variety at Clifton-on. Bowmont gave 13 tous $14 \mathrm{cwt}$., and there were practically no diseased potatoes, only an occasional one such as, I am told, is commonly seen in nearly all cases, whereas there were 7 ewt. $2 \mathrm{lb}$. of diseased potatoes in the case of the Balderston experiments with the Up-to-Date variety. The Evergood variety gave less in quantity than we obtained from the Up-to-Date variety, and was frec from disease, so that had I bcen allowed to eompete I should have come out at the top with the aid of a variety which stands fifth on the list, and shown a much larger profit, as I uscd neither dung nor artificials. See also page 119.

Turnips Grown without Manure-In the Big Haugh field some drills of turnips were sown withont any manure in 1901 and 1903, and answered so well that $I$ this year ventured on sowing a whole field (the East Countridge) with thcm. The result has been most aatisfactory, and competent judges have declared that it would be impossible to have a finer crop of turnips.

How most Cheaply to Re-Seed Pastures.-Superior grasses are liable to decline in pastures, because the culms are eaten by stock, wlile inferior grasses, in quality or productive power, like holcus lanatus, bent grasses, and crested dogstail (the last, though a good grass, is a small producer, and it is not desirablc to have a large quantity of it) tend unduly to increase. Mr. Faunce de Laune sought to overcome this by turning ont stock at the time when the flowering culms were growing, and re-stocking after they had seeded; but this course would often not suit the circumstances of the farmer, and I think it would be better to burdle off a strip on the side of the field on which the strongest winds blow, and then remove the hurdles after the seed had fallen or been blown across the field. I am led to 
suggest this from having observed how cocksfoot spread in the southerly portion of the Alghope field from a strip cut off for planting. In cases where the winds are not strong, it would probably answer better to enclose a strip of about an acre in the middle of the field, and then shift the hurdles each year. By this process the whole field could be cheaply re secded, and, as I have elsewhere shown, letting up the grass would destroy the moss, which commonly exists to a greater or less degree in nearly all old pastures, and would heavily re-seed the enclosed portion, as letting up the grass opens the ground and favours the germination of the seed.

Importance of Rolling Land when Laying Down to Grass.-Grass seeds often fail from the want of moisture close to the surface. This want can be diminished by fine tilth and heavy rolling. Both tend to raise water from below by capillary (frem capilla, a hair) attraction. This is explained by the fuct that if you immerse a tube of very small bore, and open at both ends, in a vessel of water the water within the tube will rise to a sensible height above the surface of the water in the vessel, and the smaller the tube the higher will the water within it rise. On this well-established principle depends the rising of water through the interstices of the soil, and the smaller these are made by fine tilth, and the compression of the land by rolling, the more freely will water rise to the surface. Per contra, there is hardly any capillary attraction through dust, as the spaces between the particles are too wide, aud hence a mulch of dust keeps moisture in the soil-in other words, the moisture being kept further from the surface cannot readily evaporate. A fine surface soil, then, when in a loose state, conserves water by preventing it rising to the surface; while you have cnly to roll it if you wish to bring moisture to the surface to aid in the germination of the seed and the support of the young plants which, from lack of moisture, are apt to be starved to death.

Causes of Young Pastures Failing. - When they do, it is commonly attributed to want of sufficient food for the plants. I believe it is more often owing to defective soil conditions. Dr. Voelcker, chemist of the Royal Agricultural Society of England, tells me that he has often been consulted on the point, and on analysing the soil found that there was plenty of plant food in the land if the roots could only have freely travelled through the soil. I bave the following reason for believing that the hard pan which sometimes exists just below the ploughing depth is often the cause of failure, partly because the roots of grasscs and clovers cannot penetrate it, and partly because it checks the rise of water from the subsoil. The Longshot field-Crookhouse farm (vide page 82)-is a case in point. When in ordinary arable cultivation, it never would grow grass during about 45 years backwards. I laid it down twice to permanent pasture, and in the second case with an excellent mixture, but which did not contain any of the deep-rooting plants I now use. 


\section{Eitperiences up to the end of Octoler, 1904.}

In both cases the pasture was a failure. In $1895 \mathrm{I}$ again laid it down to permanent pasture. The field, now five years eld, has bcen througheut a complcte success. This I attribute to the decp-rooting plants used; and espocially the chicery, which was a very large crop, and which, as described at page 82, went straight down into the subsoil, after penetrating the very hard pan whicb lay below the ploughing depth. From the facts connected with this ficld previous to my occupation of it, and which I have personally ascertained frem the former tenant, $I$ have reason to surmise that the failure of land to grow grass and clover well, either when in retation husbandry or being laid down to permanent pasture, must often be ewing to hard pans below the ploughing depth, and this, of course, makes it the more advisable that plants like chicery and burnet, which can penetrate the hardest pans (vide page 82 ), should be freely used.

But besides the evils arising frem hard pans, there is the fact that our soils are not kept sufficiently open owing to the deficicncy of humus in the land, and hence the rocts cannot readily traverse the soil, which, as Dr. Veelcker has shewn, often contains eneugh plant food if it were fully available for the use of the plant. If, then, you do net give the plant a soil well opened up, and kept open by humus, you must spend mere money in manure. In other words, as far as the plant is concerned, a small quantity of manure in an epen seil is of more practical value than a much larger quantity of manure in a seil of inferior physical condition. There are three losses entailed by inferior physical cenditions of soil--(1) That the plant is less able to contend with adverse seasens; (2) that the expense of manurial application must be greater; and that (3) much of the manure that is applied in excess of the requirements of the plants will be lost by waste or downward percolation, while much of it is liable to enter into insoluble compounds in the soil, ns, for instance, phosphates of alumina and iron.

Importance of Drought-resisting Plants. - The severe dreughts of 1898-99 proved the great value of the mixtures used, as in the former year we had about three and in the latter two tons of hay an acre. In 1899 the results were most rcmarkable, as the land was exposed, light, and shallew. We were indebted for the bulk of the crop to the kidney vetch and clever (the late-flewering red clever used stands drought in a wonderful way), and especially to the former. The field (vide remarks on kidney vetch) was a veritable easis surrounded by a girdle of scorched hills, and with any mixture erdinarily used the crop must have been a disastreus failure.

Aftermath must be Lightly Grazed.-The Inner Kaimrig (sown in 1895) gave 2 tons of hay an acre, which is a heavy crep, considering that it is the pocrest field on the farm, and grazed well till it was ploughed up at end of 1899. Bowmentside field, sewn in 1897, gave in 1898 about 3 tens an acre of hay. It is ene of the best fields of the 
farm, and yet it has grazed badly, though it was top-dressed with dung in the autuinn of 1899 ; while the Inner Kaimrig had no manure, and the grasses in the Bowmontside field still remain poor and weak, though the pasture has quite closed up at the bottom. Though the season of 1898 was one of drought, and thus unfavourable to the Bowmontside field, much of the unfavourable result is, in my opinion, to be aeoounted for by the fact that the aftermath was closely eaten; while I took pains to see that, in the case of the Inner Kaimrig, it was lightly grazed, as the land was of such poor quality. In grazing, then, the poorest field on the farm, though unaided by manure, has beaten one of the best, though it was aided by manure. This experience supports that of Mr Knight (vide page 5l).

Effects of the System in Preventing Loss from Wash.- On August 23, 1900, a most severe thunderstorm raged along the Cheviots, inflicting great damage, and especially in the case of turnip fields, where soil and turnips together were in some cases washed right off the land. In the ease of the three turnip fields at Clifton-onBowmont, one of which received the water from a steep hard hill above, there was no loss. In the latter case no muddy water left the field. It was all absorbed in consequence of the decaying turf in the field, and rose in the shape of clear water at the foot of the field, running out under the gate for several days. The Harewells field, in 1903--a very wot year-showed the same results as regards the absence of wash.

Lffects of the System in Abolishing Weeds.-By taking turnips after grass instead of oats, the cereal crops with which farmers begin their cropping rotation, you spring any weed seeds there are in the field, whereas in the ease of taking oats after grass the tendency is to plough down, and so conserve both weeds and their seeds. As we take a second turnip crop before laying down, this, of course, still further cleans the land, so that weeds are abolished by the time we lay down to grass. We then so fully fill the field with grass plants, and hill up every vacaney by re-sceding if necessary, that there are practically no weeds in the pasture, a fact to which my attention has been called by more than one visitor.

Effects of Haying Land First Year.-All our experience proves that if the land is heavily cropped with hay the first year to the extent of from two to three tons an acre, farmyard manure should be applied before winter sets in. If that is not available, apply superphosphate and kainit, but no nitrates, as these encourage the grasses at the expense of the clovers. I have sinee eome to the conclusion that even if farmyard manure is available, it is not advisable, for the sake of the pasture, to have a crop of more than 2 tons of hay in good and $1 \frac{1}{2}$ in the case of light land, and that the crop should be diminished by light grazing in the spring. 
On the Quantity of Clover Seed that Should be Used.-It is eustomary in Seotland to sow from 10 to evon $14 \mathrm{lb}$. of elover with the mixtures used in rotation husbandry. Our nsual seeding, which we find ample, is $1 \mathrm{lb}$. of alsike, $2 \mathrm{lb}$. of late-flowering red elover, and $2 \mathrm{lb}$. of white clover. At the most we use $2 \mathrm{lb}$. of each kind. With $2 \mathrm{lb}$. of white elover we have abundanee of the plant, and in one five-year-old grass field it has been abundant throughout. An agrieulturist of great experienee in Northumberland informs me that he had noticed the rapid disappearance of elovers in pastures when sown in large quantities ever since he could remember anything. Red elover is only a degree more diffieult to grow than white, and is liable to fail, he says, from the same eause; but when he used $2 \mathrm{lb}$. or $3 \mathrm{lb}$. of white elover it gradually inereased as time went on. And the dreaded fourth year never eame. Were it not that the plants were liable to be destroyed by slugs, in the event of the early summer being wet, he would only sow $1 \mathrm{lb}$. That was his experience np to 1893, but in a letter received from him in Oetober, 1900, he informs me that he has continued lis experiments, and for the last few years only sown $1 \mathrm{lb}$. per acre of white elover, and no elover of any other description. Our experienee this year certainly seems to show that even with $5 \mathrm{lb}$. we have been sowing teo inuch. In the case of some acres cut off at the head of the Outer Kaimrig field for plantiug, at an elevation of about 800 feet, I ordered half of the grass part of the mixture used in the field to be put down in the part severed for the plantation, partly for shelter to the plants and partly as cover, and partly to re-seed the fielcl. But, owing to an error, half of the whole inixture was sown, and it was rather less than half, I am informed. The clovers thus sown in error were rather less than $1 \mathrm{lb}$. each of alsike, late-flowering red elover, and white elover. With this small seeding we had sueh an enormous crop of clover that the plants of the plantation were mostly smothered, and I thought all the grasses must be so too; but these have now sprung throngl the decumbent elover to such an extent that I have ordered the ground to be continued as an experiment, and not to be replanted for another year. This accidental experiment has, as regards red elover, proved most interesting, as it has been shown that this elover lasts longer than is usually supposed. The land was sown in 1899, and yet there was an abundunt supply of red elover in flower in 1903, and I exhibited at a meeting of the Fariners' Club at Kelso on November 20 th of that year plants in flower, and about 4 feet long.

Fillin! up Vacant Spots in Iirst Year's Grass. -I have previously called attention to this (jage 67). Sinclair points out (page 165, 4th edition) that even in a field where blanks are not very noticeable, owing to the leaves of the plants covering the ground, they will amount to from 10 to 15 per cent. of the area. It is important to remember that, if a field is not fully shaded with grass, vacant spots-small though they may be-much inerease the loss of moisture from the field, especially in the case of drying winds. Young grass plants 
more often suffer from want of moisture than from want of inanure. It is important always to use a rake to cover the seeds. I once found that in the case of a tilly ridge there werc a considerable number of vacant spots, which I was at a loss to account for, till the steward told me that he had not used a rake, but merely scattered the seed on the ground, because in the case of other fields he had found that the re-seeding had succeeded without any raking. In certain soils it would, no doubt, but even then the use of the ruke is advisable, as the seeds can be covered with soil, when they would be less visible to birds and mice. It is of the utmost importance to fill the field with grass plants, because (1) more stock can be kept, (2) weeds can bo excluded more effectually, and (3) every part of the soil will be at once permeated, and so kept open by rootlets. Farmers have in some cases refused to credit the account of the stock we have kept per acre ; but if they will fill up their land with plants which produce abundantly, and are of rapidly-reproductive, drought-resisting, and deeply-rooted character, they could keep one-third more stock, and keep it in much better health and condition, and be sure, too, of much better crops when the land was again ploughed up.

Letting up Fogged-up, or Mossed-up, Hill Pastures. -It has been previously pointed out that letting up pastures destroys the moss, and it would be important to experiment as to how far it would pay to let up portions of hill pasture by keeping stock off till the autumn, or by hurdling off a section of a pasture each year.

Moss-Important Result in Outer Kaimrig.-This field was laid down to grass in 1890, but with only a most trifling amount of deep-rooters-1 lb. of chicory, $3 \mathrm{lb}$. of burnet, and $1 \mathrm{lb}$. of kidney vetch. Four years afterwards it showed so much moss that I ordered it to be ploughed up. It was re-laid again in 1899 - in 1903 and this year (when the field is being ploughed up) there is no moss. I attribute this happy change partly to a large supply of deep-rooters being used, and partly to the vegetable matter from the ploughed-up turf.

Grass Inoculation, or Laying Down Land to Permanent Pasture by Transplanted Turf.-I began to experiment as regards this many ycars ago, but did not continue to do so, as I came to the conclusion that all our old pastures were too full of weeds and inferior grasses to justify inoculation from them. My late factor, Mr. Thomas Elliot Boog, visited Kimbolton, the Duke of Manchester's seat, to look into the system as practised there, and a letter from him on the subject was published in the Kelso Mail of January 12, 1878. His conclusion was that "the process of inoculation of grass lands is to be commended to any one wishing to lay out, say, a park round a mansionhouse, and it is a question which I leave to your readers whether it might not be extended with advantage and profit to other and 
unore extenstve occupations." Now that a perfectly clean pasture, undisguishable from old grass, can be created under my system of farming in four or five yeirs, it seems to me that the whole subject should be reinvestigated, and especially with reference to laying down clay lands to grass, when it would be desirable to create a strong turf as soon as possible, in order to lessen the puddling of the land from the tread of stock. After inoculation such clayey lands might be sown with chicory and burnet in order to insure the land being kept open, and if some seeds of the larger grasses wero sown in addition, a turf closely rcsenbling old pasture could be created in about two years.

Success of the System as regards Crops, Stock, and Cultivation. Lord Leiccster (vide page 18) found that he could produce bettcr crops on poor land without manure than he could produce on good land under the old four-course system, if only he laid the former down to grass for a period of not less than six years, and, after ploughing up, began his rotation with turnips. This gave time for the turf to rot, and then he was sure of a good crop of corn the following year. My experience is the same as Lord Leicester's, but, as I have explained (page 19), I feel sure that, with the mixtures I suggest, a much better turf can be produced in four years than could be produced in six years with the mixture used by Lord Leicester. The period he requires-a minimum of six years-is, if my mixture with deep-rooting plants be used, longer than is necessary, and, so far as our experiences go, would not be as suitable for a tenantfarmer. I need hardly say that all views on this point must be formed in accordance with the circumstances of each particular locality - i.e. a longer period under grass may suit some districts and a shorter one other localities.

Effect of System after Ploughing the Second Turf.-Thongh the advantages of the system are at once apparent, it is not till the second turf is ploughed up that the immense effect of plant roots as tillers of the soil is fully apparent. The first turf does much, of course, in the way of ameliorating the soil and adding to its bulk; but the ease with which the second turf is ploughed up, and worked for turnips, shows a complete amelioration of the plyysical condition of the land, the cause of which is at once apparent when, on closer inspection, you find it to be interpenetrated with rootlets and vegetable matter in various stages of decay. It is now a good nest for plants, and the results of this are apparent all along the line, on the turnips, oats, grass, and the hay crops, while a great improvement takes place in the health of the stock-partly from the plants used (some of which, like burnet and yarrow, have a proved good effect on the health of sheep), partly from the variety of food existing in the pasture, and partly from the land being in a more bealthy condition, as a deeply-aerated soil, well supplied with humus, at once dries up quickly after rain, and yet maintains itself in a sufficiently moist 
condition from the moisture-retaining power of vegetable matter. The results of the whole surroundings have had a rcmarlsable effect on the sheep at Clifton-on-Bowmont, and not only has their health, condition, and quality improved, but the death-rate, which, in the case of flocks kept partly on hill lands and partly in fields in the case of large farms, is about 5 per cent., has fallen to about 3 per cent. The healthy conditions have, of coursc, told, as we have before seen, most markedly on the turnips, which are quite free from disease, though the seascn has been most favourable to the appearance of this most serious evil--one of the worst that the farmer has to contend with.

Safety of the System as regards Hay and Pasture.-One of the most experienced farmers on Bowmont Water once told me that he estimated that they suffered from drought one season ont of three. Since taking up the Clifton-on-Bowment farm, in 1887, our hay crops have always been good, though we have had some seasons of severe drought, besides other minor droughts. In one of these, with the old system, much of the stock would have had to be sent off the farm; the flocks in the neighbourhocd greatly suffered, while we had abundant feed, in consequence of the drought-rcsisting nature of the mixtures used, and it may be mentioned that the stock kept considerably exceed that formerly kept on the farm previous to my occupation of it.

Decomposition of Vegetable Matter more Rapid on Warm Slopes.In Keith's "Agriculture of Aberdeenshire," page 637, it is stated that " in thin soils, incumbent on gravel, decomposition of vegetable matter is more rapid than its reproduction; and being, when decomposed, soluble in water, it is carried through the porous subsoil along with the lime, animal manures, and whatever else water can hold in solution. For this reason land of this description having a south exposure is generally more shallow and exhausted than when screened from the sun's heat by an inclination to the north." At the present time, when our farming system requircs to be largely remodelled in order that we may successfully grapple with the difficulties of the age, this is a point of considerable importance, and deserving of further investigation, in order to estimate exactly the cffects of the various aspccts in the case of thin soils overlying porous subscils, or which have been well drained. In such cases it seems evident that the warm aspects should be kept in grass as long as possible, and, when taken up, should be cropped with turnips, and laid down to grass the year following, as the waste of vegetable matter and manure is far greater when the land is under plough than when it is lying in grass. No experiments have been made that I am aware of in order to determine the comparative loss of nitrates on the various aspects. Dr. Keith's book, which I have alluded to previously (vide page 59), was published in 1811, and furnishes us with more than one illustration of the great neglect of Government in failing to keep alive and direct continuous attention to points of 


\subsection{2 linericuces up to the end of October, 1904.}

the greatest importance to British agriculture. It is constantly being assumed that farmers may be relied on for adopting whatever course will pay them best. There never was a greater delusion. More than one hundred years ago the superiority of cocksfoot to ryegrass was amply proved. The former, from its superior productive power, is cheaper than the latter. The former tells in the most superior manner on the subsequent crops, and in ameliorating the condition of the soil. But the farmer still prefers the practically dear ryegrass to the cheaper and more advantageous cocksfoot.

Manures used for Turnips at Clifton-on-Boumont.-First crop taken after grass-6 cwt. to $8 \mathrm{cwt}$. of basic slag, $1 \mathrm{cwt}$. of sulphate of potash, and 1 cwt. nitrate of soda per acre. Analysis, 26 to 30 jer cent. total phosphate. Fineness, 80 to 90 per cent. will pass through sieve 10,000 to the square inch. Second crop after oats-5 cwt. to 6 cwt. bone manure per acre. Analysis, 2 to $2 \frac{1}{2}$ per cent. ammonia, 32 to 35 per cent. of phosphates, 24 per cent. of which are soluble. If the field seems poor it receives the larger quantity stated, and if in good heart the lesser.

Difference between Five-coursc Rotation and that on my Farm.Our rotation is as follows:-Turnips out of grass, oats, turnips, and either oats or barley with grass seeds, when the land is left for four or five years in grass, fields being taken up again a year earlier or later as may appear advisable from the condition of the grass. If we take three rotations of eight years each, which is practically $\mathrm{my}$ system, there will be twelve years of grass, six of turnips, and six of corn. Taking five rotations on the five-course system, there would be ten years of grass, ten of corn, and five of turnips. The great change in the system is that by altering the old system from grass crops in divisions of two years each to the new one of putting them into periods of four years each, I am enabled, at no greater average cost per annum, and even at less, to put down a first-class grass mixture which will not only yield much more and certain food, but leave behind it for the succeeding crops a rich and deeply rooted turf.

Comparison of the Results of the New System at Clifton-on-Bowmont with those of an adjacent Farm. - I have found that the Inner Kaimrig field of 25 acres has kept as much sheep stock as the 87 acres of the fields of an adjacent farm, where the soil and situation throughout is certuinly better than that of my field, which is by far the poorest on the farm, or certainly was so till well supplied with humus from the ploughed-down turf. The adjacent farm is kept on the old five-course system, and the mixtures used are clover and ryegrass. But this is far from being all. When my neighbour puts down turnips he will have to manure them with dung or artificials, and will probably do so with both; while the fine turnip crop grown in the adjacent field (East Countridge) to the Inner Kaimrig, without any manure, proves that my land requires neither. 
Success of the System as regards T'urnip Disease.-While I never remember to have heard such numerous complaints as regards this in the district there is not a sign of it at Clifton-on-Bowmont, and our tnrnips (about 70 acres in three fields in different parts of the farm) have looked most healthy throughout, and one of the fields has not been limed within the last forty ycars. While not denying that this disease may be propagated, even when good soil conditions exist, I am satisfied that, as in the case of man and animals, healthy surroundings will keep off disease, or reduce it to a minimum, even when the season is most favourable to its appcarance. In the case of the Clifton-on-Bowmont fields there was an ample supply of vegetable matter from ploughed-down turf, and the whole soil was thus admirably calculated to withstand vicissitudes of weather. And that favourable soil conditions are of the utmost importance as regards the diseases to which turnips are liable, we have cxcellent confirmation in the case of the Crow Wood field, on the Linton farm, which was once in my hands. This $I$ found, on a careful analysis, had less than $\frac{1}{2}$ per cent. of lime in the first nine inches of the soil, and it has not been limed within about the last fifty years. I was urged to lime the field, but refused to do so, as I could hcar of no turnip disease. The farm was let about thirteen years ago, and the tenant informs me that on the part of the field which consists of a fine sandy loam there is practically no disease-perhaps a turnip here or there; while on another part of the field, where the soil was of a different character, the disease had in formcr years made its appearance, but was checked by an application of lime. But, as we have seen, the disease practically has been non-existent on the sandy portion of the field, though it contained so little lime that agricultural chemists tell us that crops, under such low lime conditions, cannot be profitably grown. Good physical conditions, then, whether in the case of a soil well permeated with vegetable matter, or in the case of a sandy loam of equally good conditions, being favourable to the health of the plant, seem equally unfavourable to turnip disease. Large sums are spent in heavily liming land for no other reason than because it is a preventive to turnip disease. But from $m y$ long experience on this estate I am strongly of opinion that all the money spent on remcdies or preventives might be saved were the land well stored with turf in various stages of decay. My experience in the case of my Indian coffec plantations strongly confirms this view. As long as our soils were stored with the vegetable matter of the primeval forest all diseases to which our coffee was liable only existed to a trivial extent, but as the land became exhausted of its vegetable matter, and our soils thus lost physical condition, such diseases much increased. They can, however, be again reduced if the soil is dressed with applications of top soil taken from forest lands. I am now applying the same treatment to my coffee that $I$ am to the Clifton-on-Bowmont farm-i.e., applications of vegetable matter in various stages of decay, through the medium of jungle top soil in the former case and turf in the latter. Since writing the preceding 


\section{Esperiences up to the end of October, 1904.}

remark I have been told by Mr. Lillie, the tenant of the Burnfoot farm, that he has no turnip disense on his highest and poorest held, while he has a bad attack on a low-lying field, which is onc of the best on the farm. In the former casc the land had never been limed, but had an application of marl about seventy years ago. This high-lying land had becn left six years in grass before the present crop of turnips had been taken, and there was a good turf. The low-lying ficld was cultivated in the five-course shift.

Why Land on My System Increases in Fertility, even though a Breeding Stock is Kept, while practically no Cake is Used, and Hitherto only a Small Quantity of Artificials with Turnips.-This is a point alluded to in the letter of a tcnant-farmer quoted in the Preface, and has puzzled him, and many others, not a little, seeing that, as he points aut, even valuable old pastures quickly degenerate when a breeding stock, or young animals, are kept without extra cake feeding. The explanation is that the old pasture only produces white clover, which is a comparatively small collector of nitregen ; while with my system, once every eight years, a large heavy crop of red clover and kidney vetch is grown, which supply a large quantity of nitrogen to the soil, while the deep-rooting plants bring into usc much mineral matter which is cuite out of the reach of the grasses. With these manurial agencies, and the rich turf we can now grow in four years' time, we can keep that breeding stock which old grass cannot do without deterioration, because we supply the soil with a large amount of humus. The effects of this are fully enlarged upon by Warrington, Roberts, and other writers. The presence of humus conserves manure (ammonia) in the soil that would otherwise be washed out, and a soil destitute of humus will contain hardly any nitragen. The fertility of all virgin soils is largely owing to the nitrogenons humus they contain. What plants most require are things dependent on that physical condition of the soil which, with the aid of humus is so fully supplied-air, moisture, and warmth. The importance of humus in all light soils is immense, as it enables such soil to retain manurial matters. Humus also brings into action the inert mineral matter of the soil. Finally, with the aid of the deeplyrooting plants $\mathrm{X}$ use, the humus is in every rotation more and more deeply distributed in the soil, and the area of root range is con. tinuously being so enlarged. These points, and others to which I have elsewhere alluded, fully explain our ability to produce crops which have surprised the farmer alluded to in the Preface, as well as many of his friends.

Advantages of Deep-rooted Plants. - The results which have been attained from filling the land with deeply-rooted turf are as follows :The crops ripen earlier. The land is warmer. It dries much more quickly. Carting on the land does little harm to it, or young grasses and plants. Superfluous moisture passes downwards so rapidly that all wash is avoided. The land can be much more easily and deeply 
ploughed and worked. The deep-rootcrs can penetrate the hardest pans. Weeds are absolutely extinguished, and for the last eleven years there have been none worth removing. No risk of clover failure, though there has been much failure on adjacent farms. No turnip disease, though there has been much in certain seasons, with the exception of one small portion of the land, and that only occurred oncc. No manure required except some artificials with turnips when first turf is ploughed. As far as we can see at present, none is needed when second turf is ploughed, as the land is then fully charged with deeply-rooted decaying turf. Products of all crops certain, either in very dry or very wet seasons. More stock can be kept at same cost. They call be kept in much better health owing to the properties of some of the plants used. Less capital is requircd for working the farm. As the deep roots decay the land is permeated to its greatest depth (chicory will go down from $3 \mathrm{ft}$.' to $4 \mathrm{ft}$. in fifteen months, and $1 \mathrm{ft}$. 6 ins. in three months) with vegetable matter. The land can thus be deeply aerated, and more moisture carried into it to the advantage of the land in droughts. In dry weather the land cools sooner, and more dew will be precipitated. By the steady increase of humus, and the deepening and tilling of the soil by roots, the fertility of the land can be continuously improved without additional expense: Manurial matter which bas sunk low in the soil can be rctrieved by the deep-rooters. Land well supplied with humus retains manure heat which would otherwise be lost. Tough, clayey, and unworkable soils, which readily run together, can be ameliorated by the system, and completely altered in character. Finally, roots, by virtue of the acids in them, can utilise portions of the mineral matters locked up in stoncs. I have now given twenty-five distinct advantages which will certainly be obtained from the adoption of my system. I may add that owing to the want of the means of duly keeping up a good supply of humus in the land the soils of Great Britain are, to a very large extent, in deplorably bad physical condition, and this has been much worsened by liming and the injudicious use of artificial manures.

The Downward Penetration of Chicory and Burnet Roots.-In consequence of the Kale having washed away part of the bank of a field on the Morebattle Tofts farm, we have this year easily perceived the value of these plants in opening up hard pans, and acting at once as drainers, aerators, and tillers of the soil. The seed of the plants I am about more particularly to allude to was sown in 1897, the land was hayed the year following, and grazed for three years afterwards, when the field was ploughed up. A strip on the margin of the river was left, and in it were chicory and burnet plants. Two of the former were carefully taken up. The chicory was in flower, and the plant was 5 feet 2 inches above ground, while the root measured 4 feet. 5 inches. The root for about a foot from the surface was much crooked, but afterwards went straight down through a very hard clay pan about 9 inches 
thick (a speciunen of which, not unlike a pieee of soft rock, is shown at Clifton-on-Bowmont along with the entire plant), and thence downward through a hard clay into the gravel which lay below it. The hard pan, and the hard clay beneath it, are, together, 32 inebes in thickness. The root near the surface was $4 \frac{1}{2}$ inohes round, and $1 \frac{1}{2}$ ineh at about one foot down. Another plant was removed, and has also been preserved. This divided into eleven roots elose to the surface, each about $1 \frac{1}{2}$ inch round down to about a foot from the surface. The main root went down 3 feet 4 inches. I may liere mention that $I$ have obtained from the Continent six varieties of chicory for experiment, with the view of ascertaining the kind most suitable for agricultural purposes. Chicoly lasts in the land longer than is commonly supposed, and where only two pounds per acre were sown eleven and a half years ago, and the land (kept in permanent pasture) has in that time been hayed four times, there is still a fair proportion of plants in vigorous condition.

A burnet plant taken up at the same time had a tap root descending straight dowuward through the hard pan to a total depth of 2 feet 2 inches. Near the surface the root was one ineh round, and at about a foot three-quarters of an inch. The plant is a very fine one, and shows its suitability for such soils. Its value for hard, dry, shallow soils is well known to those who have observed this valuable plant. It met, I may here obscrve, with much attention from agriculturists in England about from 100 to 150 years ago, if I may judge by the long notice of it in the "Complete Farmer," which was published in 1793. Burnet is there recommended as a valuable fodder for winter, and early in the spring, and it is noticed that it not only remains green in hard frosts, but increases in bulk and grows if the winter should be mild. The straw was found to be very useful fodder for horses, cows, calves, and sheep, and the chaff of great value if mixed with any other ordinary chaff. Burnet seed was found to be as good as oats for horses, and for these it found, therefore, not only hay but corn. One of the farmers quoted in the article was satisfied "that there is no better pasture for eows, whether milch or barren, than burnet." Mr Young (afterwards Sir Arthur) is quoted as follows:- "Experiments have been made in most parts of the kingdom that prove the exhausting quality of rye-grass; its narrow leaf, and fibrous roots, class it in this respect, as well as its botanical arrangement, with corn; but the broad leaf of burnet, and its deep carrot root, indicate the contrary effect; and aecordingly, in several trials that have been made, it has been found to ameliorate. The poorest soils in the kingdom agree well with it, even such as are too poor to produee any other herb. The hot pungent quality of the plant has been found exeeedingly advantageous to sheep touched with the rot." Another writer quoted in the article alluded to (Mr Pitt) thinks the plant a good one $t o$ sow, instead of ryegrass, with clover or trefoil, being abiding, very early in spring, extremely hardy, 
bidding defiance to frest, and sustaining the chilling blast of the enst wind without facling.

It may be of interest to mention that in Bacon's "Essays," the ene entitled "Of Gardens" mentions the plants which perfume the air most delightfully when trodden upen and crushed. These are burnet, wild thyme, and water mints. "Therefore," he says, "you are to set whole alleys of them, to have the pleasure [of the perfume rising around you he means], when you walk or tread." I may add that we have a Shakesperean reference to burnet in King Henry V., Act V., Scene II.

The even mead, that erst brought sweetly forth

The freeklod oowslip, burnet, and green clover.

Effects of the Excessive use of Ryegrass. - It is well known that almest any opinion, hewever unsound itmay be, is, when once adopted, very hard to kill. Perhaps it is clung to with all the greater persistency because in time it is often assumed to be the result of a long and sound experience. The clinging to ryegrass is no exception. For about 100 years the objections te it have been pointed out, and attempts made to bring about a decreased preportion of it in grass seed mixtures. In Keith's "Agriculture of Aberdeenshire" (1811), which was a centinuation of $\mathrm{Dr}$ Anderson's original report of 1793, it was condemned as an exhaustive grass, and it is recommended that landlords in their leases should limit its use, while for poor land it was said to be one of the worst grasses ever known. William Curtis, in his Practical Observations on British Grasses-I Jendon, 1805-hits the origin of its usc whon he says that it was owing to its being a common grass, the seeds of which were easily collected. He also notices that holcus lanatus was the next grass, the seeds of which were collected and sown, and obviously for the same reason, like Keith, he, conmends ryegrass for rich meadows, but condemns its use fer upland pastures and dry situations. The writer of the article on Pasturage and Agriculture in the "Encyclopædia Britannica" for 1797 considers ryegrass unfit fer pastures that are to lie for more than two or three years. Sinclair, as we have seen, writing in 1825, limits the use of ryegrass for permaneut pasture to 1-20th of the mixture, while for the alternate husbandry he advises a mixture of three-fourths cocksfoot, the remainder of the mixture to consist of six grasses and clevers, of which ryegrass was one. In 1833 Mr Lawsen, ef Edinburgh, took up the subject, and carries us back to the original reasons for using this grass-namely, that the seeds of other grasses were difficult to obtain, which they undoubtedly were. The effeet on British agriculture by his recommending a large use of ryegrass in grass nixtures was most unfortunate, and I have heard one of our most intelligent farmers say that had cocksfoot been used instead of ryegrass in the rotations, their difficulties would have been much lessened, for coeksfeot in three years provides much vegetable matter to add to the humus of the soil, and it is 
to the absence of this humus, as I have frequently pointed out, that we must almost entirely aseribe the ruinous decline of fertility in British soils. The ryegrass question seems subsequently to have gone to sleep till 1882, when my late friend, Mr C. Faunce de Laune of Sharsted Court took up the subject in a valuable and widely-known paper, which was published in the Journal of the Royal Agricultural Society of England (Part I., No. 35) in 1882. This article, as is well known, not only aroused attention to the subject of ryegrass, but called attention to the enormous adulterations in the grass seed trade, and thus paved the way for much of what has since followed, and, as Mr Hunter points out (vide p. 79), if $\mathrm{Mr} \mathbf{F}$. de Laune had not gone back to the teaching of Sinclair to find out the truth, we should probably have been pretty mueh where we were twenty years ago. But the evils arising from the excessive use of rye. grass have since been found to be far more extensive than was originally supposed, and if the reader will turn to the paper I delivered at Cambridge this yenr (vide Appendix VII.) he will see that the greatest evil lies in the effect it has of diminishing the clover, with which it is usually associated-effects which have been fully proved, as I have shown elsewhere, and which have been proved again by the experiments of the Fifeshire Agricultural Association, which show that the amount of clover rises or falls as ryegrass is diminished or increased. But perhaps one of the best evidenees of the small amourst of red clover produced when it is associated with ryegrass bas been met with on this property, one of the tenauts on which makes imnually large purchases of ryegrass and clover hay from various farms in the neighbourhood, and for many. miles around. I have constantly observed and inquired into these purehases, with the view of noting the proportion of clover that appears with the ryegrass. An occasional cartloar may show a fair amount of clover, but if the fields in Scotland generally (and I have no reason to suppose that things materially differ here from the rest of the eountry) show as little clover, then there can hardly be said to be any scientific rotation crops in Scotland at all-in other words, the alternation of crops which derive nitrogen from the air with those which must derive it from the soil. All the clover losses may not be attributable to the ryegrass, but that a very large proportion of these are bas been amply proved by the experiments made on the subject. I know of nothing more striking in the whole history of the neglect of agriculture by the British Government than the fact that it is solely from the want of Government experimental farms that such a vast injury should have occurred to our soil, for, had they existed, farmers would have beon duly warned of the evils arising from the excessive use of ryegrass, and the immense losses that have ensued from failing to acquire atmospheric nitrogen, and the humus to be derived from elover roots, would have been largely averted. In this connection it may be added that, had my system of farming been pursued, a large proportion of the sums paid to the foreigner for nitrates would been saved. 
General Success of the System.-This has been shown most conspicuously in the case of the Inner Kaimrig, a field pronounced by a very competent judge to be, when $I$ took it in hand, not worth 5 s an acre, and, by the former tenant, the worst field on the farm, a long" ridge of it being black moorland soil. And yet this field, now (1904) young grass (sown up with a crop of oats in 1903) bas this year kept more stock than all the fields of an adjaeent farm, the land of which is far superior in quality and situation. These aggregate over 87 aeres, while the Kaimrig field is only 25 acres. The field* has never been manured since it was enclosed from the hill about 70 years ago exeepting with some artifieials with the turnips, and, as shown in the Preface, there is practically no cake fed on the farn. This field has far exeeeded my utmost expectations, and is a most valuable praetieal illustration of what poor, worn-out land is eapable of produeing if you elothe it with a deeply-rooted turf, which has been built up on a strong leguminous foundation of clover and kidney vetch.

Next to the Kaimrig lies the East Countridge field, now in turnips out of grass. Though for the last two years I had suceessfully grown on a small scale turnips without any manure, this is the first whole field in which I have had the moral courage to grow the crop without any manure of any kind excepting turf. The results have been most satisfactory, and eompetent practieal judges deelare that the erop could not be surpassed.

The Bank field, now four years old, shows a fine turf full of white clover, the presence of which in quantity is always a sign of a thriving pasture. Aceording to my system, this field ought to have been ploughed up at the elose of the year, but the turf is so fine that the field will be given another year in grass.

Next to the Bank field is the Harewells field-a steep stoney fieldwhieh shows results almost more remarkable than those obtained in the Inner Kaimrig-a crop of hay (first year's grass) of about two tons an acre followed by a fine aftermath.

I desire to call partieular attention to these four fields, for they illustrate the chief points of my system, and, by the results, prove its value beyond all possibility of doubt. The beginning of the system, and indeed that on which it entirely rests, is illustrated by the Inner Kaimrig, which has produced a heavy crop of leguminosæ-clovers and kidney vetch - to feed the grasses sown with them, and thus form them into a rich turf. With the grasses and leguminosie are the strong and deeply-rooting chieory and burnet, which keep the soil open-in other words, till and therefore aerate it eontinuously, till the turf is ploughed up, while the strong and profusely-rooted yarrow adds at onee to the value of the pasture and the health of the stoek, and leaves behind a large store of vegetable matter. The

\footnotetext{
* From April 13 to July 23 an average of $2 \frac{1}{2}$ ewes with double lambs were kept per acre, besides 20 rams for six weeks. From Aug. 6 to Nov. 1 an average of 4 ewcs an acre. From Nov. 1 to 20 an average of 2 ewes per aere. The field could bave kept mueh more stock, but we always graze modcrately the fixst year.
} 
continuation of the system is to be seen in the shape of the turnip crop in the East Countridge field; a further result of the rotation is illustrated in the Harewells field; whilc the ultimate result is shown in the four-year-old pasture of the Bank field, which, as we have seen, will yield a fine and deeply-rooted turf to commence again our rotation system. The cereals and potato crops are always good, and, indeed, the land is now so stored with humus that it is impossible to produce an inferior crop no matter what the character of the season may be; and we have had several seasons of extreme drought, and one at least (1903) of extreme wetness. For the convenience of the reader I may repeat that our rotation begins with turnips out of grass, oats, turnips, barley or oats with seeds, and then four or more years in grass according to circumstances. Though we have adopted this system, I find that therc are in some cases practical objections to it in connection with the labour of the farm-the system giving insufficient employment to the people at one time, and too much at another, but this may be obviated by beginning the rotation with oats instead of turnips in the case of one of the fields, or even all. I consider, however, that it is of importance to begin the system for the first time as regards each field with turnips, in order to get the land thoroughly clean. I may add that whatever minor disadvantages may arise from departing from our rotation-turnips, oats, turnips, and barley or oats with sceds-the great point of deeply filling the land with humus, and tilling it with the agency of roots, would still be maintained by using iny mixture and keeping the land four or more years in grass. These are the dominating points of the situation, and the order of the crops in the rotation is a matter of comparatively minor importance, though the reader must clearly understand that the best results can only be attained by a strict adherencc to our systern of rotation.

I have to record this year one important experience, which confirms the opinion I bave elsewhere expressed in favour of laying down land to permanent pasture at two operations, partly because if done at one the land can rarely be supplied with sufficient bumus, and partly because our soils are so filled with the seeds of weeds and worthless grasses-notably holeus lanatus, or Yorkshire fog-that I do not think a thoroughly clean pasture could be created at one operation. In confirmation of this view, I may quote the case of the Island field. This was sown in 1890 (with the little Countridge field, of which it originally formed a part) with $14 \mathrm{lb}$. cocksfont, 5 of tall fescue, 3 of timothy, 3 of hard fescue, 3 of crested dogstail, $\frac{1}{2}$ lb. each of yarrow and poa fertilis, 2 of lucerne, and 2 each of alsike, white, and perennial red clover. In 1898 the field, less the Islind portion, which was then fenced off, was relaid with one of our improved mixtures, including the deep-rooting plants. This year both portions of the field were cut for hay, and though the take of grass in the Island portion in 1890 was excellent, the holcus lanatus was so prevalent that the field at a distance looked white, while the rest of the lund, sown in 1898, showed no signs of it, thaugh, as we 
have seen, it had been laid down six years previously-an ample time for holcus lanatus to show itself had it been there. These facts show how completely our system of rotation springs and destroys weeds and worthless grasses.

The Financial Results which may be obtained from the system of farming at Clifton-on-Bowmont. - I have been often asked to publish the accounts of my farm. As I have no desire to mislead the farmer (an evil that might often ensue, as was pointed out to me lately by a tenant farmer of great experience), I prefer not to do so. The object of my work is not to exhibit my skill as a stock farmer, or the want of it, as the case might be, but my skill in most economically producing cereals, potatoes, and food for stock-in other words, the introduction of all improved farming system which is calculated to attain these ends. To mix this up with the stock department of the farm would be to introduce an element of the greatest uncertainty, as it is an element which fluctuates all over these islands. Each farmer must observe what can be produced from the soil by my system of farming, and apply to the conditions of his own holding my principles and system, with whatever modifications may be suitable to his climate and present circumstances. All that the farmer requires to do is to visit one of our young grass fields, in which be will always find a large crop of clover and kidney vetch, which is the indisuensable base of the system. The steward carries a crop book of each field for the last 17 years, so that the visitor can see cxactly what the field has been doing, and how it has been treated. The steward also carries a seed book, showing cost of seeds and the mixtures used, and the visitor can learn from the shepherd what stock the field has kept. This year, for instance, the Inner Kaimrig-25 acres-has kept as much sheep stock or ratber more than the grass fields aggregating 87 acres of the adjacent farm, which is much better land by the way, but which is farmed on the old five course system, and on which the generally used ryegrass and clover mixtures have been sown, and $I$ have no doubt this is a difference that would pretty generally be found to prevail in Scotland. A reference to Rothamstead experimental field, devoted to the rotation of crops, will show him bow all the subsequent crops are benefitted by the manurial matter left behind from a large crop of the leguminosæ, and for evidence of this he can see the turnips, four years' old grass of fine quality, cereals, and potatoes, all grown without manure other than of the turf grown on the land, and only aided by the manure left by the sbeep and the dung of lean cattle, which last is generally applied to the nearest fields to the steading, all the more distant fields having to depend solely on the turf grown on them. The quantity of cake used is so small that the farmer quoted in the Preface considered it to be practically none. What the farmer could keep in the way of stock with the aid of such crops grown as cheaply as mine have been, and what he could make out of the cereals and 
potatoes, he must calculate for himself, with reference to his own surroundings, and no publication of all my profits could aid him, though it is just possible it might mislcad him, seeing that, obviously, my results might be much worse or much better than a farmer could obtrin who imitated my system. Confucius, the Chinese philosopher, once said :-"If I show one corner of a subject to a man, and he cannot see the other three corners for himself, then I can do nothing with him." In the same way it is only necessary for the farmer to visit one of my young grass fields, which are always full of leguminosæ, like the Kaimrig, and if, after going into the cost of production, he cannot see for himself all the consequential results whieh must arise from such a field, then I can do nothing with or for him.

But there is another and most important financial point to be considered. Farming, like every other busincss, consists of a capital account and the profits that may be made out of capital. It is of obvious importance that stock should be carefully taken of the latter - that it should be seen whether it is advancing, standing still, or declining. Landlords' capital mainly consists of soil, and the condition of the soil mainly depends on the amount of humus it contains. About 100 years ago Scottish agricultural capital was on a sound footing, bccause the system pursued maintained the humus of the soil (vide paper delivered at Cambridge, Appendix VII.) It is in an unsound condition now, because from continuous liming and the use of artificial manures the humus of the soil has immensely declined (hence the numerous complaints of the exhaustion of the soil), and is declining steadily cxcept in those rare cases where enough farmyard manure can be obtained to keep up the supply of bumus. The object of my farming system at Clifton-on-Bowmont is to show how Scottish agriculture' may be restored to its originally sound position-not only to replace, but to steadily increase, the humus of the soil, and render the farmer, as he once was, independent of the use of artificial manures, though, as I lave elsewhere pointed out, these may still be used under certain circumstances to a moderate extent. In other words, my farming system is direeted to restoring the capital of the landlord to its originally sound and safe position, to lessen the expenditure at present required by the tenant, and place all his crops in a safe position for contending at once against foreign competition and vicissitudes of climate. How these ends may be achieved most economically has been shown at Clifton-on-Bowmont, and our agriculture never can be restored to a sound condition unless the principles carried ont there-principles the soundness of which are admitted all the world over-are universally adopted in these islands.

The Cheapest Mixtures.-Mr. James Hunter, the well-known agricultural seedsman of Chester, has more than once remonstrated with me as regards the quantity of seed I use. If the most favourable conditions of season and soil are granted he is perhaps right, but if we 
take into consideration the old maxim, "Two courses given, when in doubt choose the safest," and add to that the Scotch saying, that "there is no use swallowing the cow and choking on the tail," I am inclined to agree with the great Arthur Young, who, as I have pointed ont, said that whatever system may be pursued in laying down land to grass, the most essential thing is plenty of seed. It should be considered in especial that where a farmer is laying down land to lie for from four to six years he should take every precaution to insure success, as if his grass turns out to be a partial failure, owing to a defective season requiring more seed than would be sufficient for a good one, all his plans would be injuriously affected, as he would obtain less hay, less grazing, and a much inferior turf wherewith to feed the subsequent crops of the rotation. I have, however, asked Mr. Hunter to let me know the cheapest mixtures be could recommend, including deeprooted plants, and, after a good deal of consideration, he has submitted the following :-

I.

Grasses and Clovers, with addition of Chicory and Bninet, to lay down Land to Grass for two years (excluding the year in which the seeds are sown).

\begin{tabular}{|c|c|c|}
\hline & $\begin{array}{l}\text { Quantity } \\
\text { per } \\
\text { acre. }\end{array}$ & $\begin{array}{c}\text { Number of } \\
\text { germinating } \\
\text { seeds } \\
\text { per acre. }\end{array}$ \\
\hline 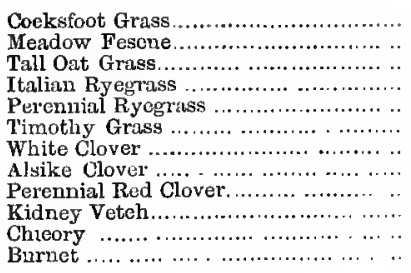 & 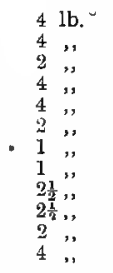 & $\begin{array}{r}1,618,800 \\
934,560 \\
248,400 \\
1,058,400 \\
856,320 \\
2,587,200 \\
717,360 \\
703,640 \\
534,100 \\
472,850 \\
569,500 \\
259,200\end{array}$ \\
\hline & $33 \mathrm{lb}$. & $10,560,330$ \\
\hline
\end{tabular}

The average price for the above seeds, of finest guaranteed quality, would be about 20 s $3 d$ per acre. 


\section{Experiences up to the end of October, 1904.}

II.

Grasees and Clovers, with addition of Chieory, Burnet, and Yarrow, to lay down Land to Grass for four to six years.

\begin{tabular}{|c|c|c|}
\hline & $\begin{array}{c}\text { Quantity } \\
\text { per } \\
\text { acre. }\end{array}$ & $\begin{array}{l}\text { Number of } \\
\text { germinating } \\
\text { seeds } \\
\text { per acre. }\end{array}$ \\
\hline 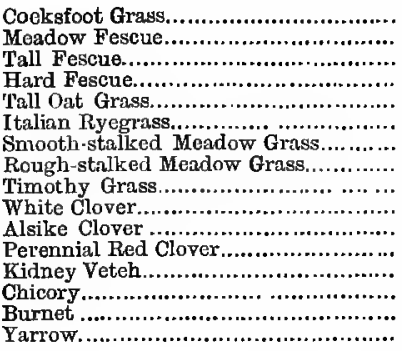 & $\begin{array}{l}61 b . \\
5, " \\
2, " \\
2, " \\
2, " \\
4, " \\
1, " \\
0 \frac{1}{3}, " \\
2, " \\
2, " \\
1, " \\
2, " \\
2, " \\
2, " \\
6, " \\
0 \frac{1}{2}, "\end{array}$ & $\begin{array}{r}2,428,200 \\
1,168,200 \\
\mathbf{4 7 2}, 320 \\
1,095,200 \\
248,400 \\
1,058,400 \\
1,581,000 \\
1,083,975 \\
2,587,200 \\
1,434,720 \\
703,640 \\
427,280 \\
378,280 \\
569,500 \\
388,800 \\
1,579,500\end{array}$ \\
\hline & $40 \mathrm{lb}$ & $17,187,615$ \\
\hline
\end{tabular}

The average price for the above seeds, of finest guaranteed quality, would be about $29 \mathrm{~s}$ [9d per acre.

\section{III.}

Selection for four to six years, having a large seeding of Cocksfoot, but with fewer of the other species.

\begin{tabular}{|c|c|c|}
\hline \multirow{3}{*}{ 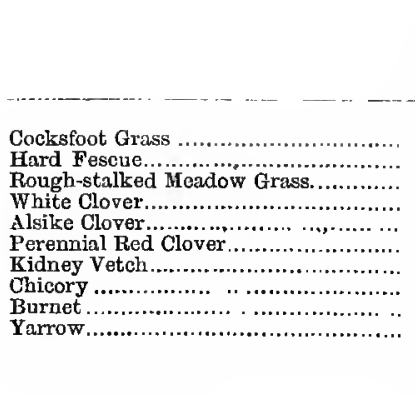 } & $\begin{array}{c}\text { Quantity } \\
\text { per } \\
\text { acre. }\end{array}$ & $\begin{array}{c}\text { Number of } \\
\text { germinating } \\
\text { seeds } \\
\text { per acre. }\end{array}$ \\
\hline & 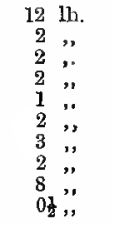 & $\begin{array}{r}4,856,400 \\
1,098,200 \\
4,335,900 \\
1,434,720 \\
703,640 \\
427,280 \\
567,420 \\
569,500 \\
518,400 \\
1,579,500\end{array}$ \\
\hline & $34 \frac{1}{2} \mathrm{lb}$. & $16,090,960$ \\
\hline
\end{tabular}

The average price for above would be about $29 \mathrm{~s}$ per acre.

Mr. Hunter, in whose judgment and experience $I$ have great reliance, and who has worked in conjunction with me for many years, and annually visits my farm, thinks No. III. mixture "decidedly inferior" to No. II. I do not. My factor, who also has had much 
experience, and manages the farm, is at variance with me as regards the mixture I am using this year, and thinks that the mixtures previously used could not be surpassed. These differences show that we have yet a great deal to learn as regards this important subject. I trust that those who may adopt my system will carefully record their experiences, and, if they will be good enough to send them to me, thcy will be useful additions to our present information.

\section{The Work of the Board of Agriculture:-}

1. In grants for agricultural education and research the Board spends from $£ 7000$ to $£ 8000$ a year.

2. Nearly all the suggestions and experiments given in their reports tend to involve the farmer in some expenditure beyond what he at present incurs.

3. But, as a rule, farmers have no money to spare for any extra expenditure, and the few who have are afraid to risk it, as the outlay might be lost owing to defects of season or a fall in prices.

4. It must, then, be clearly proved to the farmer that any suggestion made to him must yield distinct advantages, combincd with a reduction in the present cost of production; a diminution of risks as regards crops, stock, and from adverse seasons.

5. What is the essential basis of the highest agriculture? It is that the soil should contain a considerable proportion of vegetable matter in various stages of decay. It is this which gives the great value to virgin forest soils and to newly-enclosed pasture lands.

6. But if, and when, this vegetable matter declines to a low level, which it, of course, soon does unless supplied in some way, then all the difficulties of agriculture begin. The plant is involved in them because its roots cannot, as a rule, readily penetrate soil which is not kept open by humus ; the agriculturist, because he has to spend more money in cultivation and manure, and even thell obtains results far inferior to those which can be obtained from a soil well supplied with humus, if the land is aided by a slight degree of cultivation and a very small expenditure in manure. Then when the land is deficient in humus, as nearly all our cultivated lands are, the risks from defective seasons increase, there is loss food for stock, and plants are more liable to disease and to suffer from the attacks of insects.

7. With the great evil of defective soil conditions which underlies our agricultural difficulties the chemist cannot grapple, nor can all the education and experiments on which the Board spends from $£ 7000$ to $£ 8000$ a year.

8. On the Clifton-on-Bowmont farm I have grappled with our agricultural difficulties as to system (though improvements are yet to be made before it can be brought to perfection), but, so far as the public is concerned, I have only grappled with them on paper.

9. From the numerous mistakes liable to be made in working the system, and in matters which, though to the uninitiated apparently trifling, largely influence results, I feel sure that much disappointment and loss must ensue unless those desirous of adopting my system 
have opportunities of studying it in the field in all its details, and are practically shown the importance of carefully attending to them.

10. For the general adoption of the system three things are absolutely necessary-(1) That farmers should be able to study the details of my srstem on a farm conducted as mine bas been, on a system that is within reach of any ordinary farmer; (2) that he should have the financial results clearly proved to him; and (3) that seedsmen should be compelled by Act of Parliament to guarantee the purity, trueness, and germinating power of the seeds they sell.

11. The first two difficulties can be successfully overcome if the Goverument takes over my Clifton-on-Bowmont farm, and uses it as at basis from which to start sevcral such farms in various parts of the kingdom; but after a practical experience of more than is quarter of a century, I feel sure that no rapid progress can even then be made unless the same policy is pursued in the case of seeds as is pursued in the sale of other articles where the purchaser is protected from adulteration by Act of Parliament.

12. If the Government were to take up a poor, exhausted farm, as Clifton-on-Bowmont was when $I$ took it in hand, it would require from ten to twelve years to prove, to the satisfaction of farmers, what the Government could now prove were it to take over the farm and spread intelligence as regards the system.

13. Unless the Government accepts my offer of the farm at market rates, the results proved on it would certainly be lost in the event of my death, and the valuable details of many experiments of great practical importance would disappear.

14. From studying Arthur Young's great unpublished work, and observing, from other sources of information, what valuahle experiences and discoreries have been gradually lost sight of from the inertness of our Government in ficiling to record, and practically illustrate by demonstration farms, facts of the greatest value to agriculture, I feel confident that the views I have above expressed are sound.

15. From the numerous visitors to Clifton-on-Bowmont $I$ have received most gratifying opinions as to the value of my work. An agriculturist, whose opinion I highly value, in writing to me lately, said-" What I saw the other day convinces me that you have revolutionized the methods hitherto pursued, proved to the hilt that the old are very inferior in results to those you advocate, and I cannot but believe that sooner or later-the old dies hard-what you have so persistently laboured at will be generally adopted."

16. Though work on the lines, as shown in the reports of the Board, cannot accomplish the ends indicated in par. 10, I by no means wish the reader to infer that the work of the Board is of little value. All that I wish to insist on is that it never can be of the value that it might be unless it is accompanied by practical examples like those on $\mathrm{m} J$ Clifton-on-Bowmont farm-examples which 
show how agricultural improvements may be carried out, in some cases without additional cost, and in others with a considerable saving of the expenditure at present incurred.

Concluding Remarks. - When visiting Clifton-on-Bowmont one day with an intelligent gardener, I remarked-" Is it not wonderful to see such a fine crop grown on such poor soil ?" He replied-.." Give me a good turf, and I don't care what the soil underneath it is "-a point he practically illustrated as to the value of turf by robbing my park of it whenever ho could, though he had fall coninand of all kinds of manures. I may remind the reader here of the quotation on the title page, where it is declared that "To RAISE a THICK TURF ON A NAKED SOIl, WOULD BE WORTH VOLUMLS OF SYSTEMATIC KNOWLEDGE." This is what bas been done at Clifton-on-Bowmont. In little more than two years we can now raise a turf which, at a little distance, looks like old pasture, and on a close inspection might be taken for five-year-old grass, while in five years we have grown pasture that no one could distinguish from old grass. I much regret not having kept note of the remarks made by agriculturists-to the amount of one, hundred a year-who bave visited the farm. On remarking to one of them that some of them had said that what they saw had been a revelation to them, he said - "And it is a revelation to me too." When lately sbowing an old agriculturist from East Lothian the Kaimrig field (vide page 138) he finally observed, with a strange mixture of wonder and annoyance in his face- "We have been like children." In some instances we have certainly trebled the letting value of the land. Dr. Voelcker (chemist of the Royal Agricultural Society of England) this year remarked when visiting the farm that I should have kept in each field an untouched patch to show what the land originally was, for that it was now difficult to believe how bad it had been. What the tenant who had for long occupied the farm declared to be the worst field on it is now so changed that farmers will not believe in its ever having been bad land. But just as land of originally good quality, when mixed with a suitable proportion of vegetable matter, may be turned into the worst possible land when this necessary agent has been exhausted, so may the very worst land be raised to the value of good if you " raise a thick turf on the naked soil," and if we keep on raising another before the preceding one has been exhausted we shall have done all we can to promote the fertility of the soil, and, therefore, the condition of agriculture. I once said to an old tenant on the estate - "How much more stock can you keep on your young grass fields since you have adopted my advice as to altering your grasses ?" " I can keep," he said, "one-third more stock," which, I need hardly say, doubles the value of the land. "Now," I said, "I wish to ask you another question. Did you not at one time consider me to be (the fate of most innovators at ficst) a madman?" $\mathrm{He}$ laughed heartily, wagged his head from side to side, and said-"Olh, no, no, no!" but in a tone which meant "Yes, yes, yes!" It may not 
be uninteresting to mention that it was a remark made by this tenant which led to inuch of the valuable results we have arrived at. He once said to me, many years ago-" What we want is something green and sappy to go with these grasses when they dry up in summer." "You want, then," I remarked, "something which corresponds to the dry grass as turnips do to hay." "That's just it," he replied. I then sent to Mr. James Hunter, of Chester, for a list of all those plants which stock would eat, and which would not dry up in summer, and my subsequent study of the consequential results arising from their use showed me their immense value in at once tilling the soil, adding to our stores of reliable food for stock, deeply manuring the land, and improving the health of crops and stock.

One word more. There are large areas of land in these islands steadily going from bad to worse. They are not suitable for permanent pasture, and still less are they suited at present prices for profitable arable cultivation under the old system. Much of what is still kept in arable is steadily declining in value, and no wonder, for, to quote again my late friend, Mr. Faunce de Laune, "farming, as it is practised now, is more often the act of destroying natural fertility"-he means by running out all the vegetable matter in the soil-"than adding to it, and it is therefore no wonder that the land becomes impoverished." From the impoverishment of the soil, and large areas being allowed to what is called "fall down" to profitless pasture, cottages are being rapidly emptied, and the whole conditions and prospects of our agriculture are most unsatisfactory. How this condition of things may be ameliorated I have shown in these pages. It now only remains for the Government to propagate what I have eventually, after inany years of labour, proved to the hilt. 


\title{
APPENDIX IV.
}

\author{
NOTE BY DR. VOELCKER \\ ON COMPARISON OF THE SOILS OF OLD CHEVIOT TURF AND \\ FIVE-YEAR-OLD PASTURE.
}

An examination which I made of two samples of soil from the Clifton-on-Bowmont farm-the one being from old hill-side Cheviot turf, which has been unploughed from time immemorial, and the other from a spot only a few yards off the other, but on which $\mathrm{Mr}$. Elliot has adopted his new system-yields results which may have some interest.

The new pasture was five-year-old.

The old hill-side turf showed on the surface some coarse, mostly dead, tufty grass, which could in great part be pulled up easily with the hand. Then came a top-layer of black peaty matter extending 4-5 inches deep, and in this was a mass of roots crowded together, but not passing down freely and regularly into the subsoil. On testing the peaty portion with litmus paper, it was found to be extremely acid. It also held a considerable quantity of moisture. The soil below this retained to some extent the acid character, and then a more stony subseil was reached.

The five-year-old pasture, on the othcr hand, had on the surface a very fair covering of good grasses, cocksfoot being prominent. The roots from these grasses and other plants did not collect together in a matted form, as was the case with the old Cheviot turf; but they went down into the subsoil strongly and regularly. There was no accumulation of humus matter in excess, true soil being formed almost to the very top. The reaction of the topsoil to litmus paper was only slightly acid, and this disappeared entirely in the subsoil. The soil was not nearly so spongy and moisture-holding as was the Cheviot turf, but seemed in a good physical condition throughout.

Portions of the different layers, and average samples of the whole, were taken in the case of both soils, and the vegetable matter, moisture, and nitrogen determined. The principal results were :-

Cheviot Turf. Five-yr. -old Pasture.

Vegetable (organic) matter in average

Per cent. Per cent.

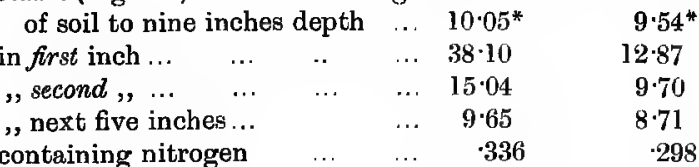

Moisture-

$\begin{array}{rrrrrrr}\text { in topsoil } & \ldots & \ldots & \ldots & \ldots & 64 \cdot 76 & 41 \cdot 82 \\ \text {, subsoil } & \ldots & \ldots & \ldots & \ldots & 37 \cdot 46 & 25 \cdot 94\end{array}$


From these results it appcars that though the old Cheviot turf has been down so long, and has had such a time for the storing up of vegetable matter, yet, on taking the soil to the depth of nine inches, there is not half a per cent. less vegetable matter in the ploughed-up and cultivated land than in the old turf. This, and the very different appearances presented by the soils, led me to examine further, and see in which part, or layer, of the soil the excess vegetable matter was. The figures show that this was by far the most prominent in the first inch-i.e., where the matted ronts were, and with consequent absence of real soil formation.

Still more pertinent is the difference shown by the two samples in respect of the moisture they held, the Cheviot turf being spongy and moist throughout the whole topsoil, while the five-year-old pasturc was uniform soil throughout, and seemed well drained, and not in stagnant condition likc the other. This, of course, carries with it most important conscquences as regards the health of stock grazed upon the respective pastures. Though the figures do not show that there is actually more, or even as much, vegetable matter in the five-year-old pasture as in the old Cheviot turf, the form in which it exists, and the general conclition of the soil induced by its presence, arc vastly superior in the case of the newer pasture. I should describe the old Cheviot soil as one which was sour through accumu. lation of vegetable matter and retention of moisture, producing an acid and unhealthy condition of the soil, preventing its proper aeration and drainage, or the healthy penetration of the roots into the subsoil. On such accumulation of acid matter alone coarse and inferior grasses would grow, thrive for a time, and then die down, in part or whole, adding further to the matting of dead or dying roots. On the five-year-old pasture, on the contrary, there is not this stagnation: the vegetable matter is, by aeration, infiuence of drainage, cultivation, \&c., brought into assimilable, instead of unhealthy, condition, and soil formation, instead of humus accumulation, is the result.

These points, to my mind, bear strong evidence to the superiority of the newer pasture, and to the efficacy of the system which Mr. Elliot pursues.

November, 1900.

J. A. VOELKER.

\section{SECOND NOTE BY DR. VOELCKER.}

In November, 1900, I appended to Mr. Elliot's new edition of his book, "The Agricultural Changes required by these Times," a note on the examination of some soils from the Clifton-on-Bowmont farm. In these I made a comparison between an old hill-side Cheviot turf and an adjoining one laid down five years previously with Mr. Elliot's mixtures. The general bearing of the observations and analyses was to show that, though the old turf had accumulated rather more vegetable matter and nitrogen, yet this was confined practically to the very top portion, which consisted of a matting of roots and 
rootlets, and which held moisture to a considerable extent, but did not allow of its percolation to the lower layers, or the ready penetration of the roots of the grasses into the subsoil.

Since that time I have had under observation other fields at Clifton-on-Bowmont laid down by Mr. Elliot, and these I have visited regularly, watching thcir progress as compared with that of the old turf. The question arose in this connection whether, as the pasture goes on from year to year, and as it improves (as is quite clear to anyone having it, as I did, under regular observation) the soil itself becomes deprived of, or else is cnriched in, organic matter and nitrogen. For the purpose of ascertaining this, if possible, I have had samples taken each year of the turf and soil from a particular spot, and I have examined and compared the several blocks thus successively removed. The field in question was Bank field, laid down in 1900, and samples have been taken in 1901, 1902, 1903, and 1904. The sample taken in the first year (1901) showed the same characteristics as compared with the old Cheviot turf as were instanced in my note in November, 1900. There was no matting of roots at the surface with accumulation of organic matter there, but the roots showed themselves penetrating regularly downwards.

In the second year (1902) there was not noticeable any great change; but, still, there was some increase both of root growth and of the extcnt to which the vegetable matter penetrated down into the soil.

In the third year (1903), however, there was decidedly more root growth, and on this occasion a second sample-of the second depth of nine inches of soil-was taken and analysed, this showing that organic matter, together with a considerable amount of nitrogen, existed in these lower layers.

In 1904 (fourth year) a further sample was taken, and this very clearly showed a great increase in the amount of roct growth, and the penetration of the humus to a greater depth. Moreover, the character of the soil itself had considerably altered, it being, as compared with the samples of the earlier years, much more friable and in generally nizer condition. The, analyses of the various samples are appended, each being taken on the first six inches of soil from the surface, except the second sample of 1903 , which was of the six inches taken immediately after the removal of the first layer of nine inches. The figures are :-

\begin{tabular}{|l|c|c|c|c|}
\hline & 1902. & $\overbrace{\text { 1st depth. 2nd depth. }}$ & 1904. \\
\hline & Per cent. & Per cent. & Per cent. & Per cent. \\
\hline Organic Matter.......... & 8.98 & 8.96 & 6.03 & 9.61 \\
Nitrogen ............... & .263 & .300 & $\cdot 210$ & $\cdot 285$ \\
Equal to Amnionia........ & .319 & .364 & $\cdot 255$ & 346 \\
\hline
\end{tabular}


It is not maintained that anything more than general conclusions can be drawn from these figures, but they show that between the second year and the fourth there has been no diminution, but rather an increase, in both organic matter and nitrogen; also that the lower depths of the soil have received supplies of both vegetable matter and nitrogen, whereas, as was shown in the case of the old Cheviot turf, these were accumulated more in the top surface. This wider distribution of the supplies of vegetable matter and nitrogen is of more importance agriculturally than their accumulation in quantity in any particular layer, for, as shown before, the latter may bring with it an unhealthy condition and stagnation. The strongest evidence of improvement, however, is shown in the marked increase from year to year in the root growth and the ready penetration of the rootlets into the subsoil.

January, 1905.

J. A. VOELCKER. 


\section{APPENDIX V.}

\section{SHELTERS.}

That shelter is "half meat" (i.e., food) is an old saying on the Borders, and, in confirmation of this, I may mention that my late friend, Mr Fannce de Laune of Sharsted Conrt, found that a sheep shelter he had put ap paid, in fonrteen days' time, interest on the outlay incurred in making it. He had two lots of sheep, which were being fed on oilcake, and which were regularly weighed, and the increase of weight in the lot that had the bonefit of the shelter was such that it, in a fortnight, yielded the financial result I have stated. Although, however, the facts previously given are well known it does not seem to be, at least practically, known that sbelter affords a very large increase in the growth of food for stock. I have long been aware of this, but was more particularly struck with it this year in the case of the Harewells field, which is fully protected on one side by a plantation, and partially so on the other. The field was young grass, and was cut for hay, and it was interesting to note that as you got away from the reach of the shelter the yield of grass gradually declined towards the unprotected portion of the field, and, probably, to the extent, in the most central portions, of abont 25 per cent. But if the stock and the grass require sbelter the plantations, when young, equally require it, and perhaps in a greater degree, and it is of obvious importance to devise some means of at once sheltering stock, grass, and plantations, till the last has grown sufficiently to afford the desired shelter. The following remarks with reference to shelters for hop gardens and orchards have been supplied to me by the kiodness of a friend, and I have no doubt may be useful for the information conveyed, and as a means of calling attention to the whole subject, so that improved methods of sheltering young plantations, stock, and grass may be devised.

With the view of providing practical protection for a young plantation I am experimenting with larch poles abont 12 feet in height, and 6 feet apart, with stays on the sides from which we have onr strongest prevalent winds. From pole to pole $I$ am putting stretehes of rabbit wire netting, and such a structure will sift the wind (to use a Kentish expression), or divide it, and so break its force to a considerable extent, and for a considerable distance. I shall probably connect the poles with rope or wire, besides staying each pole on either side. Should rabbit mesh prove so small as to get snowed np, a larger mesh might be used. When the plantation has grown up sufficiently to afford the desired shelter the windbreak might be removed, and used for another plantation. I may mention that on this property we have a narrow strip of plantation running ap the slopes of the bill to between 800 
and 900 feet above sea level. It is very narrow towards the upper end -about 40 yards wide-and, seen at a distanee, resembles bare poles against the sky line, with a faint streak of green at the head of them. Yet these poles, so the shepherd reports, distinctly diminish the violenee of the wind. At Clifton-on-Bowmont, at an elevation of about 600 feet, I have beell surprised to find the sheltering effeet of firs, and other trees, in a plantation about 30 yards wide, and whieh is merely a eolleetion of tall poles with some branches at the top 0 each tree.

With the aid of the new grass and deep-rooting plant mixtures I have suggested, stoek can be kept in the fields mueh later than they ean be at present, and as the old forms of shelter (ditehes and banks, with trees on the top, and hedges, all affording much shelter) have to a large extent been removed, or allowed to deeline, fresh forms of shelter are most urgently required. So strongly, indeed, is the desire for shelter that on this property, a great many years ago, a tenant agreed to pay, and did pay, my predeeessor the interest on the eost of making four blocks of plantation for the eentres of as many exposed fields. Plantations, too, are the more urgently needed for protecting the game, and especially the nests, which were formerly well protected by the herlgerows and banks. Eaeh plantation should have a grass margin within the fence of about 15 to 20 feet, and this should be planted with occasional bushes, and sown with seeds of the tall grasses, so that bircls could be provided with comparatively safe nesting quarters. At present it is customary to plant elose up to the boundary fences, and when the trees grow up the plantation is then of little or no use for nesting purposes. I now proceed to give the remarks that have been sent to me from Kent.

\section{HOP SHELTERS OR "LEWS" IN EAST KENT.}

These are now generally made by planting the Black Italian poplar in rows along the outside of the gardens, principally on the W., S., and S.W. sides, about three feet apart, and brushing up both sides of the row elose in every year, in the winter and spring. These plants are easily raised by putting the shoots that are cut off in the ground; they grow very fast, and are allowed to get up about 18 or 20 feet. A row of Austrian pines planted not too close together, and a row of poplars a little way off, make a splendid "lew," but takes up a good bit of ground.

How far these "lews" will act depends on the conformation of the ground. If it slopes up away from the trees, of course they will not shelter the crop so far away as they would if the ground sloped down away from the trees, or even if it were level. On quite level ground, I should say they would be useful for 100 yards. Of late years a very coarse kind of cloth has been made, and sold cheaply, of cocoanut fibre; this is fastened to stout poles 
about 18 or 20 feet long, and about as big round as small scaffold poles. It is put up in the summer, and taken down in the winter, the poles being let into the ground, and supported by a wire from the top to the ground.

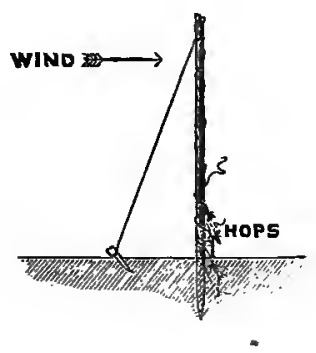

Sometimes we see a "lew" made by putting poles in the ground as close together as possible on the windward side of the garden, with a cross piece near the top just to keep the tops the right distance apart; this is bound on by cocoannt string or wire. This does oot make a very good "lew" by itself, but is useful for stopping up gaps in a live "lew."

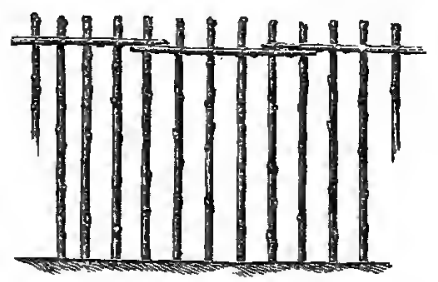

These poles would be the ordinary hop poles from 14 to 16 fcet long, and about 9 or 10 inches round above the ground. They would be put in about 18 inches.

Sometimes the cocoanut lewing is fastened to these hop poles; for hops very often it is not put within five feet of the ground.

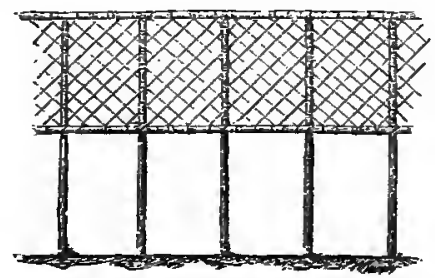


The poplar "lews" are by far the best; they grow very fast, and, if brushed in close every year, they get very thick with young shoots, which have largc and tougb leaves.

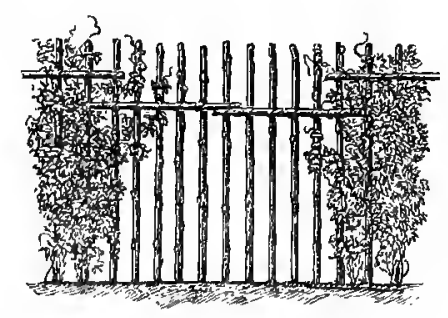

STOPPING GAP IN A LIVE "LEW." 


\section{APPENDIX VI.}

\section{SUGGESTED CHANGES OF FARMING SYSTEM.}

\section{Read at a meeting of the Border Union Agricultural Society at Kelso,} October 31, 190\%-the Right Hon. the Elarl of Dalkeith, M.P., in the Chair.

Before beginning my lecture this afterneon I will, with your permission, make a few remarks on part of the speech which my friend, Mr. C. J. Cunningham, made the other day at the Yetholm Show Dinner. The gist of his remarks on agriculture in Scotland were that it is detcriorating, and I have heard the same remark made by many others-two of them farmers of great experience. At first sight their opinions would appear to be ill-founded, for in these days we have much better agricultural machines of all kinds, better horses, and certainly better stock than we had, say, fifty years ago, and all the operations of agriculture are carried on as well, or better than they were. Where, then, does the alleged deterioration come in? It comes in, I am sorry to say, from a most serious cause-the gradual deterioration of the soil in all these cases where the land cannot be fcd with such large supplies of farmyard manure that the bumus can be adequately maintained. What proportion of the soils of Scotland have been thus harried out owing to the decline of their vegetable matter it is impossible to say, but that the proportion of land tbat either cannot be supplied at all with farmyard manure, or is only supplied with very insufficient quantities, is very large, there can be no doubt. It is in order to endeavour to remedy this serious defect in our agriculture that $I$ have asked you to listen to the following remarks; but, before proceeding, it may be as well to nete exactly how it was that so much of the land has thus been run out. It was so owing to the introduction and injudicious use of artificial manures. Previous to their introduction the farmer relied on farmyard manures, and the accumulation of humus, by leaving the land long in grass ; but, when artificial manures came in, he could give the plants a sufficient stimulus to grow a largc root system, which could not otherwise have been grown, and this root growth enabled the plant to exhaust the land. Artificial manures, if backed by farmyard manure or turf, may often be of the greatest value, by affording a stimulus at a critical period of the plant's growth. Without those aids, or ample supplies of humus, in some ferm, the stimulated plants must deplete the soil.

As we are living in changing times, the members of this Socicty will probably agrce with ine in thinking that it is very desirable that 
we should occasionally meet in order to interchange opinions and mutually communicate our experiences. You will observe that I have proposed for our consideration the changes necessary in our farming system, and I have done so because it is becoming every day more clear that farming on the old lines is unsuited to the times, and becanse circumstances are gradually becoming more and more unfavourable to it. Here, for instance, is one important difficulty to which, so far as I am aware, no attention has as yet been calledthe fact that, as compared with twenty years ago, we have a shortage of no less than one and a half millions of children in Great Britain. This indicates a movement of great importance to farmers, and if the people of these islands are showing such an active desire not to propagate their species it is high time that we should propagate our ideas as to the best way of working our farms with a smaller number of hands. For the present the anti-child-producing movement seems to be confined to the towns and inanufacturing centres, but it is sure to spread to the country; in the meanwhile there will, of course, be a much larger draft of population from the country districts, and consequently we must look forward to scarcer and dearer labour. With the other adverse conditions you are all familiar, and I need only say that all of them are, from whatever point of view we may regard the subject, unfavourable to the present farming system. What that is we all know-expensive tillage, the use of purchased foods and manures, and a rapid rotation of crops, calling for much expense and labour, and entailing much exhaustion of the soil. When prices were high they could cover the cost of production and lcave a good profit, but not so, of course, when prices fell; and we must recognise the fact that high farming on the present lines is no remedy for low prices, and the further fact that the only remedy available is to lower the cost of production. This may be effected, as I shall show, by an alteration of system, which will lead not only to the utmost ecoumy of production, but render all production more free from risk than it is at present. The whole of my experiments at Clifton-on-Bowment have been devoted to these ends, and I am now satisfied that whereas the old farming system gave us good crops at a high cost, wc can, with the aid of improved farming, produce as good, and often much better, crops at less cost, and certainly with far less risk from adverse seasons. With it we can not onlv repair the exhaustion of the soil, caused by our farming system, but continually increase its fertility, and while this can be done our expenditure can be largely reduced. These views are fully set out in my "Agricultural Changes" and "Laying Down Land to Grass." I am told that many farmers would adopt my system, either wholly or in part, but that they are deterred from doing so by the cost of the mixtures I have most recently used. One of my objects in addressing you to-day is to show how a farmer may most cheaply, and at the same time effectively, modify his farming system so as to bring it into line with the conditions of these times.

If the farmer has his land in fine physical condition, and, from 
applications of farmyard manure, well supplied with hunıus, there is no reason why he should not at once use the expensive Bank field mixture; but if his land is in poor condition he should, I think, use the appended mixture for the first rotation, as be would then avoid the risk of putting down an expensive mixture with the soil in poor condition. I began my farming at Clifton-on-Bowmont in 1887 with the following mixture :-

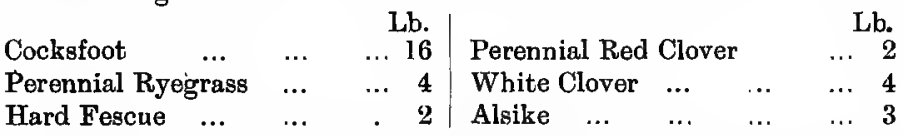

At a cost of $£ 12$ s $5 d$ per acre :

my object being to fill the land with vegetablo matter at the smallest expense. This was used for the Front and Bowmontside fields, and the rosults have proved very satisfactory. In consequence of the steep stony nature of the land 4 acres of the latter field were left in permanent pasture, and, as such, have always done well. Where timothy suits the soil and climate it may be added to the mixture, and the cocksfoot may be lessened. The quantity of clover now seems to me to be excessive, and in recent years $I$ have never used more than alsike $1 \mathrm{lb}$,, white clover $2 \mathrm{lb}$,, and late-flowering red clover $2 \mathrm{lb}$., a quantity which may still further be reduced, as I have obtained excellent results with a total of $3 \mathrm{lb}$. of clovers per acre. The mixture I would now recommend as the cheapest to be advised, and which is suitable for two or a greater number of years, and is also fairly well suited to permanent pasture, is as follows :-

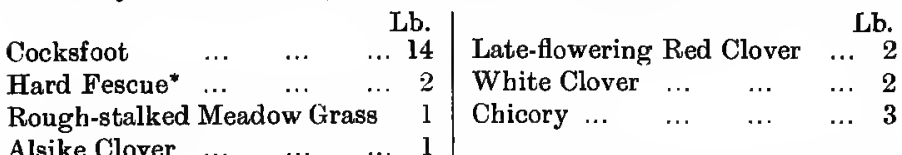

Where the land is suitable for timothy $3 \mathrm{lbs}$. of it may be added, and the cocksfoot reduced to $12 \mathrm{lb}$. I may add that in recent years, in consequence of the greatly-increased use of the grasses and plants recommended by me, they have much gone up in price, the Bank field mixture in 1890 costing $£ l ~ 19 s 5 \mathrm{~d}$, while it cost last year $£ 22 \mathrm{~s} 6 \mathrm{~d}$, and this year $£ 29 \mathrm{~s} 10 \mathrm{~d}$; but $I$ am informed, on good authority, that prices will again fall when the attention of seed growers is directed to the subject.

When the natural grasses are used alove, or with but a very small quantity of ryegrass, it is important to note that the clover never fails, even though there may be an almost universal failure of clover in cases where ryegrass alone is used, or with only a small quantity of natural grasses; and though the Clifton farm was in poor condition when I took it in hand, we have never had anything but complete

* It has been suggested to me by Mr. Hunter of Chester, that up to 700 feet meadow fescue would be more suitable than hard fescue. and he points out that the former will be cheapen next season ( $7 \mathrm{~d}$ to $8 \mathrm{~d}$ per $\mathrm{lb}$.), but it should be remembered . that the lattcr is a much more drought-resisting grass, 
success in growing clover, and have had excellent results in the case of land that was only limed once, when it was taken out of the hill about forty-two years ago, and has never been manured or limed since. It is important to dwell carefully on the great value of clover and its only too common failure, which is by far the weakest point in our farming, while it ought to be, and can be, made the strongest point of all, from a manurial and physical point of view.

The principle of the rotation of crops is the alternation of crops which take nitrogen from the air with those which can only derive it from the soil-speaking generally, the alternation of the leguminosæ (of which beans, vetches, and clover are commonly used here) and cereals. If this can be carried out annually, land may be cropped for thousands of years with the addition of hardly any manure. In Mysorc six drills of a cereal crop are sown with a seventh of beans (Dolichos spicatus). After harvest the spaces between the drills of beans are ploughed up, and the crop (somewhat like a French bean) soon almost covers the ground, and is harvested in due course. The straw of the crops is eaten by cattle, and their manure is used as fuel, the ashes only being returned to the land, the decaying roots of the beans, and the atmospheric nitrogen collected by them, being the sole manures besides the scanty supply of ashes; and yet, with the aid of these resources, every year you will see a crop of corn and a crop of beans more or less good, according to the season. In our agriculture clover is, generally speaking, the nitrogen-collecting crop, but it only occurs once in four or five years, and, should the crop fail, the land must wait four or five years for another. Now the failure, or partial failure, of the clover crop means much more than the loss of most valuable food, for it means as well the loss of vegetable matter, and the atmospheric nitrogen which would otherwise have been collected through the agency of the nodules on the clover roots. The loss from the latter alone may often be estimated at about 10 s an acre. By the farming system adopted at Clifton-onBowmont, and the rejection of ryegrass, these losses can with certainty be averted.

The next weak point in the present system lies in the fact that from the use of the shallow-rooting ryegrass, and the absence of deeprooting plants which can not anly aerate, but deeply till and manure the soil, the farmer not only fails to take advantage of the natural resources at his disposal, but fails to take advantage of the stores of plant food which lie at depths below the reach of the plants he now uses. In consequence of the downward filtration of manure, it has been found that the unused subsoil is often richer than the upper soil, which alone is used by the farmer.

The third weak point in the present farming system is that when a serious drought occurs the farmer is completely at the mercy of the season. In the case of last year's drought, when there was such a general failure of grass, and especially of clover, the Bank field on my farm had a most luxuriant appearance all the season through, and the results clearly prove that, with the aid of the new farming 
system, the farmer may regurd the worst drought with absolute indifference. The facts are of such importance that I may quote the following passage from my letter published in the Scotsman, November, 1901 :-

"The Bank field consists of 27 acres, rather more than half of which is poor, stony, and exposed, and in some parts very steep land. The remainder consists of fair medium soil for that part of the country. For the last nineteen years 24 acres of the field have never been manured, excepting with the artificials used with the turnips. The remaining 3 acres have once-some years ago-had some farmyard manure, and the seed mixture used, and the reasons for using it, are giving on page 95 ( $2 \mathrm{~d}$ edition) of my "Agricultural Changes." It was sown last year with a crop of barley. From October 1, 1900, to October 1, 1901, the value of grazing and hay attained was estimated by us at $\mathfrak{f 7} 3 \mathrm{~s}$ an acre. Our estimate has been referred to a tenant farmer, who is employed as a valuator, and his estimate comes to rather more- $£ 77 \mathrm{~B} 6 \mathrm{~d}$ an acre."

From October 2, 1901, to October 1, 1902, the field has been stocked as follows, and I purposely allowed it to be so much later in the autumn and winter than was judicious in order to see how the new mixture would stand the roughest treatment; and the effect of this, as might have been anticipated, has been a decline of the clover, though this seems to be recovering, and there is now an abundant feed of grass in the field, which is still stocked with 60 ewes. The list of the stock is as follows :-

From October 1, 1901, to December 31, 1901, 4 ewes per acre, with the assistance of one cartload of either cabbages or turnips per day for the field.

From March 15 to May 24, 1902, 3 ewes and siugle lambs per acre, with the assistauce of two cartloads of turnips per day for the field.

From May 24 to July 28, 1902, $2 \frac{1}{2}$ ewes and single lambs per acre. From July 28 to October 1, 1902, 3 ewes per acre.

From May 1, 1902, to June 10, 5 cattle.

From June 13 to September 4, 2 horses.

The fourth weak point of the existing system is that the farmer is put to considerable expense is weeding his fields. I found from an estimate made for me by one of my tenants that he was spending $11 \mathrm{~s} 4 \mathrm{~d}$ per acre in cleaning a field preparatory to sowing turnips. With our system of farming we practically have no weeds, or so few that they are not worth removing. In two instances we abandoned our usual system, and took oats instead of turnips out of grass, when, of course, weeds naturally followed. It may be mentioned here that our system is turnips out of grass, then oats, then turnips, when the land is laid down to grass, with oats or barley, and kept in grass not less than four years.

The fifth weak point of the present farming system is the great cost of handling and re-handling farmyard manurc. With the new farming system you grow your manure on the spot in the shape of 
a deeply-rooted turf, which most fully supplies that humus which is the most valuable part of farmyard manure. This may now be carted direct from the steading, and scattered on the nearest grass field. By the careful investigation of the late Dr. Voelcker, it has been proved that this would involve no loss of manure (much of which is liable to loss on the existing system) though if left in small beaps on the land there would be a loss.

The sixth weak point in the present farming system consists of growing the most innutritious grass. I this year sent a sample of the Bank field hay to a friend, who obtained a pructical opinion for me from a farmer who grows hay for the Liverpool market, and the sample, I may add, was by no means a favourable one, as all the best part of the hay had been used. The farmer writes as follows :- "I only regret I have not a thousand tons of such fodder, as I should then fear neither rent day nor pay day, nor, for the matter of that, scarcely any other days; such hay as $I$ have before me wouln sell like wildfire in Liverpool, even in the face of severe home and foreign competition." It is interesting to observe how the opinion of the practical hay grower coincides with the analyses in Sinclair's work. The nutritive value of perennial ryegrass stands at 70 , that of cocksfoot 80 , tall oat grass 120 , tall fescue 94 , rough-stalked meadow grass 80 , burnet 100 , yarrow 98-all of these being grown in the Bank field mixture. Chicory stands at 60 , or nearly the same nutritive value as white clover. Sinclair gives no analysis of the kidney vetch. According to Dr. Stebler, in his "The Best Forage Plants," the proportion of nutritive matter contained in kidney vetch is greater than in red clover hay of medium quality. After enumerating thirteen grasses as being those which contain the most nutritive matter, Sinclair observes that "perennial ryegrass ranks with those that contain the least." It is not uninteresting to note that the opinions of the practical hay farmer, the analyst, and the horses all agree-the last so decidedly that they prefer the Bank field hay to oats-i.e., they will leave the latter to eat the former.

The seventh weak point of the present farming system is that, in consequence of the absence of vegetable matter in the soil, the waste on all slopes is serious, and the downward waste of manurial matters is also very considerable. When the land is well stored with decaying turf the waste is entirely averted, and the downward percolation of the water is attended with no loss, or only a trifling one, of nitrogen, as it is retained by the humus.

The eighth weak point in the present farming system is the exhaustion it entails on the soil, and of this I have heard frequent mention for many years pust, besides having a large personal experience in the matter. Perhaps the most decisive evidence on the point is contained in the resolutions passed at the first great meeting of 400 Aberdeenshire farmers at the beginning of the bad times, when they attributed their difficulties to dear labour, bad seasons, and the exhaustion of the soil. The last statement proves what must now be evident to everyone, and that is that the present farming is a 
system not for maintaining and improving, but for continuously lessening, the fertility of the soil. But though the soil has been thus exhausted from a practical point of view, it has not been se from a chemical point of view. It has only bcen exhausted of its vegetable matter. Speaking generally of most seils, a sufficiency of mineral constituents are still there to last for the crops of a great many years, but these remain inert in consequence of the exhaustion of the humus; and perhaps the most valuable and encouraging point connected with my experiments at Clifton-on-Bowmont lies in the fact that it has been clearly proved that old worn-out lands that have been crepped for sixty or seventy years, and never manured, will preducc as good, and even better, crops than they ever did if only you replace the vegetable matter which these soils contained when first enclosed from the hill. Misfortunes are proverbially said never to come single, and I may here notice that just as prices fell the Scotch farmer found himself tilling soils more exbausted than they ever had been, owing, as I have shown, to a system of agriculture which certainly tends to a yearly-increusing decline of fertility, unless, of course, in those cases where a full supply of humus is kept up.

It may be useful to sum up some of the results you will certainly obtain from the new proposed system of farming. While your seeds. man's bill per annum need not be increased, and may even be lessened, your gains from atmospheric nitrogen will be large and certain. The land will be more easily, and therefore more cheaply, ploughed and worked, while your tillage (by the agency of roots) will be deepened and improved; your weeding bills will be abolished, the success of your clover and grass will be certain, your artificial manure bills may be largely reduced; the supply of humus-in other words, the fertility of the land-instead of decreasing as it has hitherto done, will steadily increase (in some instances we have trebled the value of the land); the expense of handling and rehandling farmyard manure will be saved. All crops will be healthier and better. The health of the stock will be much improved, and, as grass is the cheapest food for stock, more luxuriant pastures will entail less cest in feeding. Lastly, by rejecting ryegrass, you will be discarding a comparatively innutritions grass, and one that suffers much from drought, and leaves little vegetable matter, in favour of the grasses used in the Bank field mixture. Such, then, are the certain results you will obtain from the proposed farming system. As regards finger-and-toe, I cannot speak so confidently. I will only ge so far as to say that $I$ have reasen to think that, with the aid of healthy conditions of soil, and especially an abundant supply of humus, and interposing, as we do at Cliftonon-Bowmont, a longer peried between the last turnip crop of one retation and the first of another, the risk from diseased turnips will certainly be largely diminished. Though we had some turnip disease in part of a field eight or nine years age, we have had nene since, cven though last year there wero many complaints of it in the neighbourheod; and in that year wo had a good crop of turnips on land which had only been limed once, 
about forty-two years ago, and it had never been manured since, excepting with the artificials put down with the turnips; but the land was well supplied with humus, and had lain in grass for a number of years. Should, then, my aurmises be correct, we should be able, with the aid of the new farming system, to save the great expense that is often incurred in liming as is temporary preventive or cure for finger-and-toe.

I now propose to remark on the various values to be derived from humus, or decaying vegetablc matter, in the soil, in order to show the great advantage of the proposcd system of farming in providing, through the agency of a solid and deeply-rocting turf, the largcst quantity of this valuable agent. Humus is that substance which gives value to forest soils, or newly broken-up pasture lands. It is at once a manurial agent, and a maintainer of the physioal oondition of the soil; but perhaps most valuable of all for its effect in conserving that moisture which is often of more importance to the plant than the presence of any quantity of ehemical manurial constituents. It is, indeed, the very life and soul of the soil, and that is why the farmer, the planter, or the gardener attaches so much importance to farmyard manure, forest topsoil, turf, or any substance which will supply this indispensable ingredient of fertile soils. These humus-supplying agents all have this immediate advantage-the fact that the results from them are certain, while the results from all purchased manures are uncertain. For the latter may be washed away, or enter inte insoluble compounds in the soils, and in the event of a drought the anticipated results might not be gained. The experience in the United States seems to be that it ncver can certainly be predicted whether profit or loss will result from the purchase and the application of nitrogen, potash, or phosphoric acid in any form. One thing is certain, says Roberts, in his "The Fertility of the Land " (Macmillan \& Co.," price 5s), and that is that the application of farmyard manure, in almost any form, will result in impreved fertility and increased profits. But this arises not from its, strictly speaking, chemical constituents, which could, of course, be supplied by chemical manures, but from the fertility which the decaying vegetable matter of the straw imparts to the soil, the most important feature of which is probably owing to the power of humus for conserving moisture, seeing that plants more often fail from lack of moisture, at a critical period of their growth, than from dearth of chemical constituents of plant food ; and it is of equal importance to note that as all the moisture in the soil may be needed, and often is needed, in the growing season, it is most advisable to store, through humus, all that can be kept in the land. In three years' experiments with farmyard manure (Roberts, p. 148), it was found that the first surface foot contained 183 tons more water per acre than adjacent and similar but upmanured land, the second 9.28 tons, and the third 6.38 , or a tetal difference in the first 3 feet of soil of 34.41 tons per acre. If, then, the Bank field was quite unaffected by last year's drought, it was mainly because the land 
was well stored with ploughed-down turf, and was therefore eapable of retaining a full supply of molsture, though the land had not been manured with farmyard manure for the last nineteen years. But there was another important reason to which I would desire to draw partieular attention-the fact that the land was thickly-shaded with plants, as it is from the want of this complete shading that the land suffers so much more in a clrought than it need. For every vacant pateh of soil is really a pump, as the moisture, rising from below, is rapidly evaporated and carried away by the wind, and water is also drawn into each pateh by lateral attraction, to be, of course, at once evaporated. Each patch, then, though only as big as half-a-orown, starves all the adjacent plants, and as these plants are commonly thinly planted in the land, and consist of the shallow-rooting ryegrass, it ean easily be understood why my field, well supplied with humus, and thiekly shaded with plants, many of them of deep-rooting character, remained luxuriautly green while those of my neighbours were dried up.

Let me now briefly enumerate the other effeets of humus. It not only supplies nitrogen, but, as it decomposes, makes some of the phosphoric aeid and potash of the soil available. By keeping the soil more open it aerates the land, and so sets free more plaut food. It enables the soil to retain manurial matter which would otherwise leach away. This is particularly the ease with ammonia, and it has been found that a soil destitute of humus will contain scareely any nitrogen. The importance of humus to light soils is enormous, as they are much less retentive of manure than heavy soils. By keeping the land open humus enables superfluous water to drain through the soil, and by keeping it more open prevents it being soured. Air, moisture, and warmth, which are all so necessary for the germination of seeds and the growth of plants, are but little influeneed by the ehemical constituents of the soil, being all more dependent on its physical condition, which ean only be effectively influeneed by large quantities of humus, which, I may observe, can, by us, be most cheaply supplied by deeply-rooted turf. It is important to notice that, as a consequence of growing a deeply-rooted turf, you can deepen the soil above and add to it below. In the case of the Inner Kaimrig field, enclosed from the bill about seventy years ago and never manured since, the ploughing depth had sunk to about 6 inches. It is now about 9 inches, 2 inches being gained above from the admixture of turf with the soil, and 1 below from the action, of the deep-rooting plants, and this depth can certainly be added to as time advanees. When growing a good deeply-rooted turf, then, you will not only be supplying much more and much better food for stock, but you will derive from it, when ploughing up, a long train of most valuable consequential results, whieh will at onee favourably influence anything you may subsequently grow, and ensure that the utmost economy of production is arrived at. Perhaps one of the most important results is that, through the agency of deeply-rooted plants, and those with a large root system, you can, 
and at no additional cost, most minutely and deeply till the soil. The amelioration of the soil from root action is indeed most marked, and our attention has been frequently called to it, and more especially in the case of the Outer Kaimrig. When we ploughed our tirst turf the work was of such difficulty that, in my " Agricultural Changes," I suggested that it might be better to begin the rotation with rape, in order that time might be given for the decay of the turf ; but the amelioration of the soil is now so great that there was no difficulty experienced in breaking up the turf for the second rotation. It is only, I may repeat, with the first turf that there is any difficulty in taking turnips out of grass. Such, then, are some of the results to be obtained from humus, and the use and action of deeply-rooted plants and grasses, and I think I have said enough to rccommend the subject to your earnest attention, for it is only through the adoption of agencies like these that we can hope to place our agriculture on a satisfactory footing.

My lecture is ended now. I am confident that the general principles I have recommended are sound, and I say so after the perusal of much public criticism on my work and opinions, and hearing many private opinions of value, and after having, since my "Agricultural Changes" was published, carefully studied the works of the American agricultural writers. But though I am confident that the general principles I have recommended are sound, it by no means follows that any cut and dried particular method of carrying them out can possibly be laid down. Each man must be left to carry them out in whatever way is suitable to the climate, and general condition of his farm and circumstances; and I will go so far as to say that not only does every farm require the principles to be worked out in a different way, but that every field on the same farm may require variations in the method of carrying out the principles of the proposed farming system.

One word more. Insist on your seed being guaranteed as to purity, germination, and weight per bushel. See personally to the mixing and sowing of the seed, and that it is sown as soon as possible after being mixed. In the spring take a rake, and re-seed with your own hands, as I have done, every vacant patch in the field, and you will then see how well, or how ill, your work has been done. In this connection I should advise farmers never to cease urging the Government to establish a central seed-testing station, where farmers could, for a small fee, get their seeds tested. This was recommended in the report of the Committee of 1900 appointed by the Board of Agriculture, but no steps appear to have been taken in the matter. This neglect of the interests of the farmers seems the more astonishing, seeing that the advantages of such an establishment have been amply proved by the Swiss Government. There is much need also for an Act to enforce that seedsinen should guarantee the purity and weight per bushel of their seeds, and that the guarantee should be stated on each invoice, as in the case when fertilizers and feeding stuffs are sold. 


\section{APPENDIX VII.}

\section{THE CLOVER MYSTERY : A PROBABLE SOLUTION OF IT.}

\section{Read at the Meeting of the British Association for the Advancement of Science at Cambridge, August 19th, 1904.}

JUDGING from my own observation, and the opinions of the numerous visitors to my Clifton-on-Bowmont experimental and demonstration farm, this subject is of increasing importance. "No one," said a visitor lately, "can be certain that if he sows clover he will be sure to get a crop of it." "If you can only solve the clover difficulty," said another, "you would be of the greatest service to agriculture." "This crop of clover," said a third, looking at a crop growing on the poorest field on the farm, and keeping 4 ewes and their twins per acre, " is worth going 200 miles to see." What a deplorable condition must our agriculture be in if such things can be said of that nitrogen-collecting crop on which the success of the subsequent crops and grazing so largely depends. The following experiment and the explanation of its results throw much light on the subject. One of $\mathrm{my}$ agricultural visitors laid down with one of my mixtures (without ryegrass) two halves of a field with seed bonght from our respective seedsmen. In both cases the production and appearance of the clover after the harvest was the same. By the spring following the clover supplied by his seedsmen had vanished, while that supplied by mine continued to flourish. Being anxious to compare the red clover supplied to me with that supplied to my agricultural visitor by his seedsman, I asked a neighbour of the experimenter to takc home some of my clover plants (grown from seed supplied by my seedsman), but he was unable to make the comparison, as not a single plant from the seed which had failed could be found. Had the whole field been sown with seed supplied by my agricultural visitor's seedsman, there would, of course, have been no clover at all, and the farmer and his friends would have said, "Oh, clover sickness again," and thought no more about the matter, such disappearances being quite common, and invariably accounted for by that supposed malady. On referring the experiment to my seedsman, and asking him to explain why my clover (supplied to me by him on a large scale for upwards of twenty years past) has always succeeded, while that of my neighbours has often been a partial, and not unfrequently a complete, failure, he has replied as follows :-

"As regards the unfailing success of your clover crop, I think this is, in the first place, due to your deep cultivation by deep-rooting 
plants; and, in the second place, to the use of seed of a good and hardy strain, and that has been grown in a suitable climate. How much is relatively due to the system, and how much to the seed, it is impossible to say; but you have abundantly proved that the two together have resulted in unfailing success. The red clover you have used at Clifton-on-Bowmont has been the late-flowering red variety, which is exclusively grown in England, chiefly on the Cotswold Hills, and the quantity of seed raised annually bears a very small proportion to the quantity of red clover annually sown in Great Britain. But there are other varieties of red clover, grown in England and other countries, which are very desirable, such as ordinary English red, Canadian, Russian, North of France, etc.-hardy sorts of large growth-and if these strains of the best quality were exclusively used in this country, and grown on your system, I do not doubt that the clover crops of the United Kingdom would be as invariably successfal as are the crops at Clifton-on-Bowmont."

The failure, then, of the experimenter above mentioned to grow clover from the seed obtained from his seedsman was evidently owing to the latter having supplied seed grown in the South of France, Italy, the United States, or some comparatively warm climate; and I think it is perfectly clear, when a crop of clover comes up in a thoroughly satisfactory manner in the autumn, as that of the abovementioned experimenter did, and totally perishes by the spring following, the failure can only be attributed to the seed having been produced in some much warmer climate than ours.

Let us now turn to the cases where the failures are partial, or, in other words, where the crop falls far short of what it might and should be. In this connection the experiments and results at Clifton-onBowmont conclusively support the value of deep-rooting plants and grasses and the system of farming adopted, which is fully described in my "Agricultural Changes and Laying Down Land to Grass."

On ploughing down the first turf in my system of rotation a great improvement in the clover crop is perceptible, but a most marked improvement is shown, which cannot be estimated at less than 25 per cent., after ploughing down the second. The increase of clover then rises in proportion as the land is filled with decaying vegetable matter, and dceply tilled with the agency of roots, which enable water to pass rapidly downwards and rise as freely, by capillary attraction, to supply the great demand of the clover for moisture. There is, then, no dfficulty in forming a decisive opinion as to one of the steps necessary for obtaining the fullest and most certain success in growing clover, and I say certain because we have succeeded equally well in growing good crops of clover in seasons of the most severe drought as we have done in the most favourable seasons.

If the preceding conclusions are sound they lead to the certain conclusion that the use of a large proportion of ryegrass is adverse to growing clover with the fullest degree of success, for it has been found by experiments made by the Highland and Agricultural Society that the amount of roots left by a mixture of natural grasses (other 
than ryegrass) and clover is about twice that from ryegrass and clover, and, I need hardly add, must bo much greater in the cese of the mixtures used by me. It must be considered, further, that as ryegrass is a rapid grower it deprives the clover of food, and, what is probably of more importance, moisture at a critical period of its growth. It is not, then, surprising to find that clover flourishes the better as the quantity of ryegrass is diminished, and its place supplied by the other natural grasses.

There are, then, three things probably necessary if we wish to grow uniformly the fullest crops of clovor, no matter what the character of the season may be-namely, (1) seed of a hardy strain, and drawn from a suitable climatic source; (2) a farming system that will deeply till the land with the agency of deep-rooting plants, and store it with much humus; and (3) the exclusion of perennial ryegrass, or its reduction to a small proportion of the mixture used.

Let us now consider the minor contributory causes of failure to grow the fullest crops of clover. These are (1) sowing an excess of clover seed; (2) injudiciously grazing in autumn and spring, more especially, of course, in the first twelve months; (3) cutting the covering crop so closely as at once to bleed the clover, and leave little shelter for the plants; (4) failing to roll the land judiciously in first autumn and spring, and especially before admitting stock; and (5) raking the stubble, and thus injuring the clover plants. As a sixth minor cause I was at first inclined to add " the too frequent repetition of clover," but, on further consideration, I have doubts as to whether the usual repetition of the plant, though more frequent than in the case of my farming system, is at all hostile to growing fairly good crops where suitable seed has been in association with little or no perennial ryegrass ; for, though my system has undoubtedly largely increased the crops of clover, we always had what farmers considered to be good crops of clover in the case of the four farms which have been on my hands, and of which I have had an aggregate experience of over twenty-five years; and also, with the exception of one field, to be afterwards alluded to, in the case of a fifth farmed by my son, and I would call particular attention to the fact that this was the case when the farms were first taken over, and before, of course, my system (excepting the omission of ryegrass) had had time to influence the crops. But when I let the best of these firstmentioned farms, the tenant had no difficulty in producing what is called clover sickness, and that, too, more than once, and in a most marked degree on one of the best circumstanced ficlds on the farm. These facts certainly seem to lead to the conclusion that if a farmer sows good seed produced in a suitable climate, and uses little or no ryegrass, he may be sure of growing fair crops of clover, though he conld not expect them to be nearly as good, nor as uniformly good, as he could obtain were the land cultivated on the Clifton-on-Bowmont system.

As the facts as regards the sole instance of failure seem of interest I give the manager's report of the field in full :- 
"STACKYARD FIELD GRASS MIXTURE, ONE YEAR'S HAX.

\begin{tabular}{r|l} 
Lb. & Lb. \\
10 & Alsike Clover
\end{tabular}

Italian Ryegrass

Cocksfoot

Late-flowering Red Clover

"The seed was put in with a good mould, with the exception of the heary clay portions of the field, which, at the time of seeding, were somewhat rough. There was not a heavy crop of barley, and there was none of the crop 'lodged.'

"There was a fair take of seeds after the corn was cut, but a want of clover, more especially on the clay portions. The seeds were eaten in the late autumn with sheep, but only to a moderate extent. When the hay was cut (a fair crop) there was little clover to be seen -none in the heavy clay parts; the same remark applies to the kidney vetch.

"It is sometimes said that "Cocksfoot does not come the first vear'-in this field Cocksfoot bulked largely in the hay crop."

It is, I think, of practical interest to add here that I have in my long planting and agricultural experience observed the same causes of soil decline both in India and in Roxburghshire, and have successfully adopted, in essentials, the same remedy in both cases. We (the planters) cleared forest lands on the Western Ghants of Mysore, and planted them with coffec. All went well till the stock of humus in the soil fell to a low ebb, when the inevitable decline ensued, accompanied by decreased production, and increased plant diseases. We then consulted the agricultural chemists, who advised varying combinations of artificial manures, but this only made matters worse, leading to a bumper crop one year and hardly any crop the next, accompanied, as might be supposed, with as decline in the quality of the berry. Then I went back to Nature, and carted on to my land immense quantities of forest topsoil ; in other words, soil rich in humus, and this entirely changed the aspect of affairs, as the land was thus restored, in a very great degree, to its virgin condition. In like manner I have treated the once run-out soil of the Clifton-onBowmont farm, where ficld after field had been enclosed from the hill. The virgin turf gave, of course with the aid of a little artificial manure with the turnips and swedes, splendid crops for a certain number of years; but as, from the distance from the steading, no farmyard manure could be applied, the inevitable exhaustion of humus ensued. There was only one way of remedying the evil, and that was to produce humus on the spot in the shape of turf. This was done with the aid of my system, and I have found, by comparative analysis, that I have not only restored the run-out humus, or decaying vegetable matter of the virgin turf, but supplied it in a much more effective degree, in consequence of my deepening the soil with the aid of the deep-rooting plants and grasses used in my mixture. Whether, then, the season is excessively wet, or one of extreme drought, we produce, without fail, the fullest crops of clover, which, 
I need hardly add, are the indispensable base of all cconomical and successful agriculture where the leguminose can be grown, and not only for the food supplied for stock, but for the physical and manurial effects provided for the use of the future crops of the rotation. To sum upif you can grow clover you can grow grass, and if you can grow grass you can, with the aid of deep-rooting and drought-resisting plants, grow in four years a turf which is manure for four crops without any added manure, either by feeding cake on the land or artificials, except, perhaps, a small quantity of the latter for the turnip and swede crops; and these I hope entirely to abolish next year, as I have found, by experiments, that after plonghing up a second turf none are required. Nor are they in the case of potatoes. On comparing my yield last year with that of the Balderston Farm experiments near Linlithgow, where 20 tons of dung and $7 \frac{1}{2}$ cwt. of artificials were used, I not only, with the aid of a good turf, beat the experiments as to amount of production, , but showed a much larger profit, as I used neither dung nor artificials. In this connection it is important to note the following, as growing potatoes, with the nse of turf alone as manure, seems to have an important effect not only as to production, but also as to superiority of eating-quality of the potatoes, and especially with reference to potato disease. The variety I used was the $U_{p}$-to-Date, and it produced 13 tous $14 \mathrm{cwt}$. per acre, and there were practically no diseased potatoes, only an occasional one such as, I am told, is commonly seen in all cases. In the case of the same variety the Balderston experiments gave 10 tons $18 \mathrm{cwt}$. $6 \mathrm{lb}$., and no less than $7 \mathrm{cwt} .2 \mathrm{lb}$. of diseased potatoes.

It is of practical interest to note the steps taken by our predecessors in Scotland to maintain the humus of the soil by diviaing farms into infield and outfield, and guarding the latter from exhaustion, as the amount of farmyard manure available could of course no more maintain the necessary amount of humns then than it can now. So far as I can judge from the leases of my property of 1782, the outfield was only to be plongbed once at the beginning of a lease, after which it was to lie three years in grass (or four years from sowing the seed, as in Scotland they do not count the first year). If ploughed again a certain course of cropping was prescribed, after which the land was to lie in grass till the end of the lease. When, however, artificial manurcs came in, such restrictions were abandoned, and field after field of the outfield was added to the infield till all was absorbed, and kept on a system which steadily exhausted the humus of the land. And this circumstance has of course been largely aggravated by the failure of the clover crop-sometimes entire and sometimes partial, as we have seen-for is it not obvious, from what I have previonsly said, that the failure of the humus limits the clover crop, and that, in turn, the failure of the latter limits the supply of the former? In this connection I may call attention to a letter over the signature of " Blue Book," which appeared in The Times of August 10th, which shows, by a reference to agricultural conditions and prices io France, that to provide cheap food you must have soil fertilized with humus, the 
supply of which has been increased, through the medium of straw, by the high wheat tariff of 1892.

In conclusion I may peint out that if, with the aid of a leguminous base, agriculture can be carried en for thousands of years with hardly any manure, our agriculture, aided as it is by the manure of animals, ought certainly to be able to do so without the aid of any purchased manures if the farmer can enly make sure of growing large crops of clever. In Mysore, the farmers sow six drills of a cereal crop to one drill of bean crep, which in its early stages is suppressed by the former. After harvest the space between the bean drills is cultivated, and the erep-not unlike a French bean in appearance-seen spreads over the greund. The straw of the creps is used to feed cattle, and their manure is burnt for fuel, the ashes only being returned to the land. These crops are repeated annually, thus giving a scientific retation (the alternation of crops which derive nitrogen from the atmesphere with these which must derive it from the seil) each year, and, with the aid of the atmospheric nitrogen, the roets of the bean and cereal crop, and the ashes of the fuel, creps, mere or less geed according te the season, have been produced for many centuries, and will continue to be produced. The scientific rotation of the English farmer occurs enly ence in four or five years with his clever crop, and if that fails he has then to purchase plant foed which ought to have been produced in abundance on the land. On entering one of my fields of clover, which was of a beautiful dark-green hue, an agricultural visitor obsorved to me "This field has been nitred." "Se it has," I replied, "but it has bcen so frem the nitrogen produced on the land with the aid of my farming system." It may be observed that when the farmer buys nitrates, he only buys a chemical agent, whereas when he grows plants which yield him nitrogen he not only acquires plant food, but a physical agent as well, which ploughs the land with its roets, amcliorates the whole cendition of the soil, and thus enables the plants successfully to centend with the vicissitudes of our climate and the diseases to which all plants are liable.

Frem what I have previeusly said it might be supposed that I think that the agricultural chemist is no lenger needed. That is far from my idea, but the chemist must become more of a farmer', and the farmer more of a chemist before either can work effectively in arresting the downward course of our British soils. For upwards of twenty-five years I have now had them through my hands on a large scale, frem alluvial flats up to elevations of about 800 feet, and of almest every kind. I have no reasen to doubt that soils clsewhere are in much the same condition, and if they are I am sure that, with the present agricultural systcm, they must gradually be deteriorating, and that the exhaustion of the seil, so universally complained of by the farmer, must be mere and more aggravated as time advances; the general conditiens can only" be impreved by providing the means for growing large and uniformly-successful crops of clever, and if this can be dene, as it has been by me en the steney, steep, poor, and exhausted lands on the slepes of the Cheviets it could much mere 
easily be done elsewhere. But an improved farming system leading to this ond can only be generally attained within a reasonable period of time if the farmer is aided by the following conditions. These are (1) the diffusion of practical information on the subject by Government Experimental Stations, (2) the provision of government seed testing stations, (3) obliging seedsmen to pass an exammation (just as druggists are) before being allowed to practice their business, (4) the guaranteeing by seedsmen of the rate of germination and purity of all seeds, (5) that agricultural chemists should have had a practical agricultural training before being allowed to practice, and (6) that the present system of conducting manurial experiments should be placed on a wider basis. To enlarge on all these points here would be impossible, but numbers 2 and 6 are of such immediate importance, and can be so readily taken up and acted upon, that a few sentences may be devoted to their consideration. As to point 2, it may be briefly stated that, with the exception of Great Britain, all the leading countries of Europe have official seed-testing stations, where the utmost facilities are given for the testing of agricultural seeds. Even Ireland, thanks to the Hon. Sir Horace Plunkett, has such a station in Dublin. Such stations were advised for Great Britain by the Departmental Committee which sat on the subject in 1900 , but the bewildering variety of our national affairs no doubt leaves little time for the Government to notice the needs of the biggest and most importaut industry in the kingdom. The sixth point requires notice at greater length.

The usual practice is to couduct manurial experiments on ordinary British soil ; in other words, soil that has been run out of humus, is therefore in bad physical and manurial condition, and which has not been cultivated nearly to the depth that it might and should be. Plot No. 1 of such land is marked no manure, and to the other plots are applied various manures, and conclusions drawn therefrom. Now if we assume that the agriculturist can do nothing further by himself to fertilize the soil, over and above what he does at present, no further steps would be required, and in any case nothing is to be said against this system, so far as it goes, but from not being accompanied by similar manurial experiments on soil which has been tilled and fertilized to the utmost (as the Clifton-on-Bowmont soil has been) through the agency of natural means, the conclusions arrived at by the experimenter must always be incomplete. It is evident then that in every case where ordinary British soil is used for experimental purposes, soil of similar character should be raised to the level of the soil on the Clifton-on-Bowmont farm and then experimented on with artificial and other manures similar to those used for our ordinary run-out soils. A similar course should also be pursued where grass lands are experimentally manured with the view of showing the effects of various manures in providing more and better food for the animals grazed on the pastures. In this way only could it be determined how far artificial and other purchased manures pay the farmer who chooses to use to the utmost, as I have, the resources 
which nature has placed at his disposal. My own experiments are too limited to enable me to pronounce a confident opinion, but, at present prices of farm produce, they lead to the conclusion that purchased fertilizers, though giving an increase of crop, do not pay after the land has been cultivated for a rotation on the system I have adopted. But should the prices of farm produce rise, such manures would certainly be required, and after a considerable lapse of time it is probable that, even with my system, certain soil ingredients would become so deficient as to give rise to a demand for purchased fertilizers. Fully to determine those important points ought to be the aim of all who are intercsted in the progress of British agriculture, for cultivation on the old lincs, leading to decreasing humus and increasing manure bills, is no more a remedy for low prices than onesided free trade is for free imports, and it is only by arriving at the utmost safety and economy of production, through the agency of natural resources used to the utmost, that our agriculture can be placed on a sound and enduring basis. When this has been attained-when the land bas been cheaply and deeply tilled and aerated with roots, and thus interpenetrated with humus-the value of the chemist and the manure merchant will be most strikingly apparent, and will be as absolutely certain as, in consequence of the low state of fertility of our soils, the value of both is at present uncertain. If you apply artificial manures to a mineralized soil you may lose much of your money if the season is either over-wet or overdry. If you apply them to soil amply supplied with humus the results from the manure are certain, as a fully humus-fed soil is able to set at defiance the vicissitudes of the season, and, besides, ripens the crops earlier (last year my barley was got in in good condition, while that of my neighbours was caught by the rain) ; and from giving a good nidus for the plants, renders them less liable to disease.

I think I have now established the fact that the future success of our agriculture depends upon growing full crops of clover, and shown how this can be done with absolute certainty, and I may mention in conclusion that I have made a list (published in The Farmer's Gazette, Dublin, November 28th, 1903), of no less than twenty-six distinct consequential advantages which arise out of growing it with the aid of the system of farming adopted on my experimental and demonstration farm. This consists of putting down a mixture of three large grasses, one small one, three clovers, kidney vetch, chicory, burnet, and yarrow, which is left for four years, or more, if desirable, and is followed by turuips, oats, turnips, and barley or oats with grass seeds. With this system weeds are so completely abolished that none have been removed from the farm for the last twelve years, and visitors have said that they had never seen a cleaner farm. The effect on the health of the stock has been most marked, partly, I think, from the drainage cansed by the decp-rooters, and partly from the tonic properties of the burnet and yarrow, and from the variety of food supplied. At a very large sale this year my balfbred ewe lambs topped the market, I obtained first prize for the tup 
lambs at the Border Union Show at Kelso, and it may be mentioned that, with the exception of some given to the 20 rams annually sold, no artificial food is ueed with the sheep stock on the 1250 acres of which the farm consists. Do not the facts in this yaper seem to show that, on the whole, the cheapest and best manure mcrchant is the seed merchant, and that he is also the cheapest cultivator and drainer of the soil, the most economical producer of meat, the best preserver of the health of stock, and the best promoter of their condition?

ROBERT H. ELLIOT.

Chivton Parg, Keloo. 
POSTSCRIPT TO PAPER READ AT THE MEETING OP THE BRITISH ASSOCIATION AT CAMBRIDGE, 1904 :-

IT may be advisable to note that my paper has been written from a practical farmer's point of view solcly. His efforts should, I suggest, be directed mainly to methods for the most economical production of crops, and the prevention of the diseases to which both crops and animals are liable to suffer from. The discovery of new manurial resources, the question of the application of chemical fertilizers, and the advisability, or inadvisability, of adopting curative methods for plant and animal diseases should be left to the scientific observer. As to the last-named, it is of importance to remember that when all the conditions are favourable to health the diseases of plants and animals exist, as a rule, in a comparatively small degree, and that they only do so to an injurious extent when circumstances are un. favourable. As regards the truth of this rudimentary fact, I have had ample evidence both in the case of $\mathrm{my}$ Indian and Clifton-onBowmont experiences, where healthy conditions of soil, and general circumstances favourable to health, have shown most marked results as regards the diseases to which animals, plants, potatoes, and turnips are liable. It is of great importance, tno, to remember that when, by preventive measures, the farmer spends money in such a way as to reduce losses from diseases, he is certain, as I have previously shown, to get a profitable and permanent return for his outlay, while the return from curative measures is always uncertain, and costly, and is generally of a temporary nature.

One word more. It is of practical interest to note that the farmers of the Eastern States of America are recruiting their run-out lands, not as farmers are being urged to do here, and are doing to a considerable extent, by purchased fertilizers, but by growing leguminous crops, by which, at the smallest cost, the land can be both chemically, and, what is generally of more importance, physically fertilized, and much of the required nitrogen obtained from the atmosphere. In this connection a question of great importance in its inmediate and consequential results arises. It is this-if the land by good farming can, with the aid of natural agencies solcly, be fully supplied with nitrogen, why should the farmer purchase it? And if there is no need of his doing so, why should the landlord have to pay, under the Unexhausted Manures Act, for any portion of nitrogen-yielding manures? It is a remarkable fact that the efforts made by the Legislature, by means of costly experiments with artificial manures, and an Act to protect the purchasers of them, should tend, not to good, but to bad farming of a positively injurious form, to a greater and greater reliance on purchased fertilizers, which must always be uncertain in their action, and often exhaustive to the soil, rather than to a reliance on that slowly-decaying vegetable matter which must yield a certain profit to the farmer, and steadily increase the fertility of the soil. And it is, if possible, still more remarkable that the Government should refuse to give compensation' for nitrogen 
stored in the vegetable matter, while it grants compensation for the unexhausted residues of artificial manures and cake fed on the land.

It may be pointed out, lastly, that besides the required seed-testing station, and an Act to compel seedsmen to guarantee the seeds they sell, an Act is urgently required in order to keep spurious, diseased, aud adulterated seeds out of the country. In America the Custom House officers take samples of all lots of seeds at the ports of arrival, and forward them to Washington for examination, and the seeds are at once allowed to pass on to their destination; but if the seeds are bad, or do not come up to a certain standard of quality, the names of buyer and seller are published, and thus public warning is given as to the holders of bad seeds. As farmers here are quite unprotected in this matter it is hardly necessary to say that spurious seeds, diseased seeds, and seeds mingled with weed seeds are imported without any restriction. It is hardly necessary to add that, unless farmers are aided in their work as the farmers in other civilised countries are, it will be hopeless to expect any rapid progress towards amending the present depressed agricultural situation. 





\title{
IMPORTANT WORKS ON STOCK TREATMENT.
}

\author{
J. \& J. H. RUTHERFURD
}

HAVE ACQUIRED THE STOOK, COPYRIGHT, AND PLATES OF THE FOLLOWING EXOELLENT PUBLIOATION :-

\section{EVERY MAN HIS OWN VET:}

a PRACTICAL MaNUal OF THE DIsEases of DOMESTIC aNIMALS, WITH THEIR REMEDIES.

\section{By GEORGE S. HEATLEY, M.R.C.V.S.}

In one substantially-bound volume, crown $8 v 0$, of 660 pages. Originally issued at $7 s 6 d$, now offered, post free, for $3 s 6 d$ nett cash.

The Separate Treatiges constitutino the Volume ahe:-

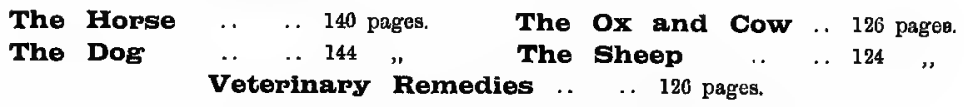

Any or all of these can be had aeparately in atout cloth pluah binding, poat free, for $1 \mathrm{~s}$ each.

To clear off a small remainder, offered at 1 s each, post free,

\section{HINTS TO STOCKOWNERS.}

By the late WILLIAM ROBERTSON, F.R.C.V.S., And Principal of the RoyaI Veterinary College, London.

\section{The Fiscal Question.}

PAMPHLET BY ROBERT H. ELLIOT. 


\section{THE BORDER FARMERS' PUBLISHING EMPORIUM,}

\section{J. \& J. H. RUTHERFURD, Squzare, IEFInSO,}

Hon. Publishers to the Border Union Agricultural Society, Call Special Attention to their well-known

\section{FARM ACCOUNT BOOKS.}

\section{The Stack-Yard and Barn Book.}

Prices, post free-Made of the best paper, and stoutly half-bnund in calf, 3s 6d, 5s 6d, and 75 6d.

The sets quoted above sre intended for the Farmer's private use, but a thinner book, less stoutly bound and without the model balsnce and some of the auxiliary peges, is got up for the Steward's keeping. Price, post free, $2 \mathrm{~s} 6 \mathrm{~d}$.

\section{Workers' Time and Wage Books.}

Drswn up for Monthly Accounts-the most useful for large Farms-

is $9 \mathrm{~d}, 2 \mathrm{~s} 6 \mathrm{~d}, 4 \mathrm{~s}$, and $7 \mathrm{~s}$ 6d.

Drawn up for Weekly Accounts - the most useful for small Farmsis, is $8 d$, 2s $6 \mathrm{~d}$, and $3 \mathrm{~s} 6 \mathrm{~d}$.

\section{Live Stock Books.}

\section{Lately Published.}

SHEEP (System for Hill Farms). New and greatly improved issue. Large oblong 4to. size; price, post free, $4 \mathrm{~s} 6 \mathrm{~d}$.

SHEEP (System for Arable Farms). New and greatly improved

issue. Large oblong 4to. size; price, post froo, $4 \mathrm{~s} 6 \mathrm{~d}$.

CATTLE, with Supplementary Pages for Swine Aocount. Oblong 4to. size; price, post free, $4 \mathrm{~s} 6 \mathrm{~d}$.

SHEPHERDS' MONTHLY RETURN SHEETS, Is per Doz.; $7 \mathrm{~s} 6 \mathrm{~d}$ per 100.

\section{The Farmers' and Estate Managers' Ledger.}

$3 \frac{1}{2}$ quires Hand-made Foolscsp, $\frac{1}{2}$ calf, Paged, Titled, and lndexed. Price, 13/6. Do. Do. Do. CASH BOOK. Price, 11/6.

North British Farmers' Yearly Labour and Live Stock Account Book.

On a New ano Simple Plan. By H. F. Everett, Edington Mains. 


CONSERVATION REVIEW. MaY. 10 , 1990 coop list

CONSERVATION RENEW: $2-4-93$ No fuitheraction 
